\title{
老年者の健康と生活構造並びに意識に関する調査研究
}

\author{
関西医科大学公衆衛生学教窒 (指導 $\left.\begin{array}{c}\text { 前主任 東田敏夫教授 } \\ \text { 主 任 原一郎教授 }\end{array}\right)$ \\ 関西医科大学第 2 内科学教室（指導 主任 塩田登志也教授）
}

川 端フミヨ

わが国の人口構成の推移を見ると, 近年, 出生率並び に死亡率の低下によって, 年令構成は大きく変化し, 高 令者人口の割合が増大している. 1980年では，総人口 中, 年少人口（ 0 才 14才） $23.5 \%$, 生産年令人口（15 才〜64才） $67.4 \%$ 老年人口（65才以上） $9.0 \%$ あ゙り， 1950年にくらべると, 年少人口の割合が2/3に減少し, 生 産年令人口の割合は, 微增 (1.2 倍)にたいして, 老年 人口の割合はほほ 2 倍になっている. 1980年の老年人 口指数 13.4 , 老年化指数 38.4 は，1950年におけるそれ ら（8.3および13.9）に比べて，それぞれ1.6倍と 3 倍近 くになっている. 将来人口推計によると, 今後む人口の 老令化はすすみ，2000年には65才以上人口の割合は $14 \%$ とみこまれ，現在の西欧先進国の水準となり，21世紀半 ばには18\%にをで高まるものとみられる。

加令 aging にともなう身体的機能の低下と生活能力の 減退は必然であり, 今後の高令化社会に向けて, 老年者 の保健医療と生活保障は緊要な社会問題となろう.「老 人保健法」制定の動きはその一つの現れである.

近年, 平均寿命の延長が謳われているが, 老人の幸福 はたんに寿命の延長だけでなく,老人がagingに伴い必然 的におこってくる心身機能の低下と疾病による生活機能 の減退を補いつつ, 人間としての「生き甲斐」を失うこ となく，生涯を全うすることであろう，それはWHO 憲 章がいうごとく，老年者の身体的状態 physical being と 精神的状況 mental being の特殊性並びに社会的生活状 況 social being に密接なかかわりをむっている. それら の「完全に良好な状態」"a complete physical, mental and social well-being” の確保が因られねばならない.

従来, 老年者の健康汇関する調查の報告1) -7) は数多 くある. また1963年以来，老人福祉法による老人健康診 查制度が実施され，1980年度には全国で246万300人の受 診者があり, 健康診断事業そのものはかなり普及したと みられる.

問題は，さらに老年者の健康を守るために何をなすべ
きか，ということであろう．それは老年者にとって「健 康である」ということの意味をふまえるとともに，老人 保健対策のあり方を見定める必要があろう。

1973年，WHO尃門委員会は「老年者社会全体の問題」 として，「老人保健対策のすすめ方」）について審議した 結果を報告した，そのなかで「高令者の保健上の原則的 な問題」として，「老化そのむのは疾病でないが，老人 は無自覚の間に生じた長期の疾患におちいりやすい，例 えば心蔵血管, 脳血管障害からくる精神疾患, 運動器官 の病的状態，聴覚，視覚障害等である．これらの疾病は 事故と同様, 他人の介助に頼らねばならない機能障害を 起しやすい」.「顕在化していない不健康を発見する総合 的な組織機構が概してできあがっていない」。

これには「疾病予防, 事故防止, 栄養的要因, 所得保 障, 退職，労働」などをあげ，また「老人医療対策」に ついて「䂆的措置」をあげ，「家族ならびにコミニテ ィとのむすびつき」「「老人医療サービスの範囲はできる だけ広く，段階的且継続的でなければならない」「必要 とするすべての人々に利用できること」などを指摘し， 「老人医療対策」のあり方について「勧告」を出してい る. 老人の保健対策は, 老人の医療・治療だけでなく， 予防と看護, さらに生活構造, 家族関係, 並びに地域社 会のとりくみが緊密にかかわっているととを示唆してい る.

老年者が主体性をるって自立的生活を楽しみ，さらに 社会生活にその一員として参加しうるか，どうかという ことが問題である．とくに老年者の「孤独化 loneliness」, 「社会的疎外 social alienation」, さらには「社会的植物人 間化 anomie」を防ぐことが旰要である。それらを果すた めに必要な社会サービスを保障することは高令化社会に おける第一級の課題であろう.

著者はかねてより，和歌山県下各地の地域住民の保健 医療活動にかかわりをもち，とくに定例巡回診療に従事 し住民の医療需要淁してきた，巡回診療開始当時， 
1960年代洼受診者には乳児，幼児等若年者が多く，投薬 を要求した. しかし最近では高令者の受診が増加し，そ の要求は投薬や治療よりも健康相談が多くなっている. とくに農漁村で注その傾向がつよい，著者は地域医療保 健活動の体験から，地域における老人を対象とする健康 管理事業の必要性を痛感した。たまたま，著者は「長寿 村」と俗称される一漁村において巡回診療活動を通じ て, 老人のくらしと健康に関する実態を理解する必要を 感じ，乙れを契機として，高令化社会に向けての地域老 人保健医療対策のあり方に関する知見を得る目的で, 老 人の健康状態の把握と, 生活構造並びに意識に関する社 会医学的調查を企画した.

具体的には，(1)健康状態，(2)身体的・精神的機能，(3) 日常のくらし方，(4)日常生活における自立性，(5)配偶関 係，扶養依存性，家族関係， 6生産的生活あるいは，社
会生活とのかかわり，(7)孤独化 loneliness あるいは植物 人間化 anomie の有無, (8)老年者の意識・欲求と現実と の関係，等を明らかにすることである.これらは高令化 社会における緊要な社会医学的課題でもある.

著者は, このような観点から, 都市, 農村, 漁村にお ける老年者を対象として，その健康状態，健康意識，日 常生活, 食生活, 㖺好, 住居, 生活状態, 年金, 福祉事 情, 家族関係, 地域人間関係, 老人の意識と要望などに アンケート調査し, 加えて, 健康診断をおこなった。こ のような総合的な調査は類をみないものであろう.あわ せて独居老人およびねたきり老人の調査をおこなった. なお, 本研究では, 老人の生活経歴の多様性に鑑み, 著者自身が個々の老人の健康と生活の実相と意識を理解 することに主眼をおくこととし，対象者数をその目的が 果しうる範囲に限定した. 


\section{第1篇 都市における老年者の健康と生活構造}

\section{並びに意識に関する調査研究}

近年における都市勤労者層における定年退職人口の増 加，勤労者世帯における扶養能力の限界，核家族化によ る扶養者離れ，住宅難など，都市化につれて老人のくら しは次第に困難さを加え，人間疎外が増大しているよう である. 老人問題は高令化社会における緊急な都市問題 の一つである.

著者は大都市における老人の生活と人間関係の実態を 明らかにするとともに, 老人の健康状態とその意識, 要 求について知見を得る目的で, 大阪府守口市において, 一連のアンケート調查と健康診断を括こない, その問題 点を考察, 検討した.

\section{地域事情および人口構成}

大阪府守口市は大阪市に北接し，国道 1 号線をかか え, 住居地域 $66 \%$, 準工業地域 $29 \%$, 商業地域 $5 \%$ の混 合住居地域である. 人口密度 $1 \mathrm{~km}^{2} 12,615$ 人. 住居の 55 \%は借家であって, 1 人当り畳数 4.5 畳末満の世帯が全 世帯の41\%を占める，庶民住居密集地域である. 1980年 調査によると, 就業人口 99,403 人, そのうち雇用者 70.2 \%を占める. 産業別人口構成は, 製造業 $34.4 \%$, 卸売・ 小売業24.2\%, サービス業 $14.1 \%$, 建設業 $12.0 \%$, 通信 業 $8.2 \%$ であり, 勤労者階層の町といえる. 守口市人口 の性別, 年令別人口構成は図のごとくである. 65才以上

守口地区・人口構成

一性別・年令別一 (1980年1月)

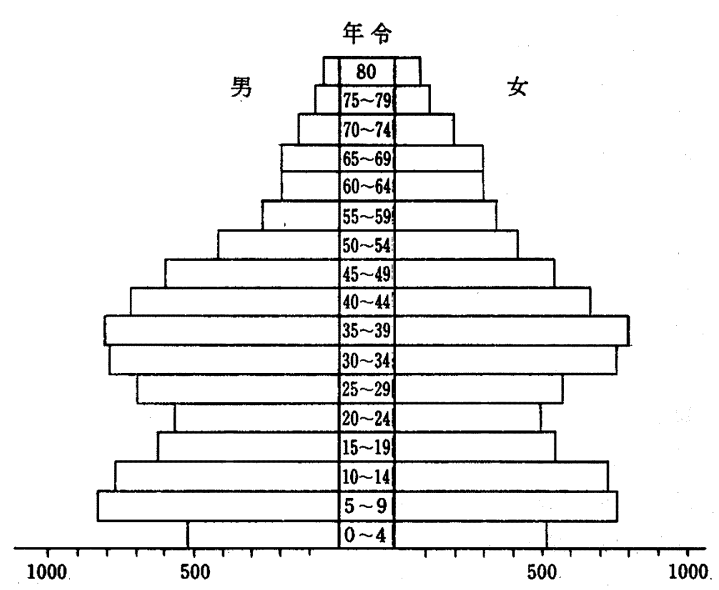

人口の割合は $6.9 \%$, 老年人口指数 10.7 , 老年化指数 27.8 であり，全国大都市並みである.

\section{I アンケート調查結果}

守口市当局, 社会福祉関係者および老人クラブ役員の 協力をえて, 当市の地域特性を考虑しつつ，3地区（守 口，三郷，庭洼東）をえらび，それぞれに居住する65才 以上の老年者から調査対象者数を任意抽出し，209名を 選定し, 所定のアンケート調査をおこなった. 調查期間 : 1979年 4 月〜1980年 3 月.

\section{1 調查対象}

調查数209名, 男86名, 女123名. 年令別に注65才〜 69 才 82 名 (39.2\%)，70才～79才 102 名 (48.8\%) 80 才以上 25名（12\%）である.（表 1)

\section{1 ) 調査対象者の前職}

調查対象となった男の老人の前職は, 生産工程従事者 $26 \%$, 事務従事者 $23 \%$, 公務員 $14 \%$, 販売従事者 $6 \%$, 保安整備員 $4 \%$, 運輸從事者 $2 \%$, サービス業 $2 \%$, そ の他の労働者 $6 \%$, 農林業 $7 \%$ あり, ほとんどは勤労 者であった。

\section{2）配偶関係と世帯類型}

配偶関係：男の老人は89\%が「配偶者あり」にたいし て，女の老人の $2 / 3$ は配偶者なし」であり，その大部分 は死別である. 離別（10\%）はもっぱら女にみとめられ る.

世帯類型 : 「家族同居」119名（56.9\%)「老夫婦暮し」 57 名 (27.3\%)，「1 人暮し」33名 (15.8\%) である.「老 夫婦暮し」と「1人暮し」の割合にはかなりの男女差が あり，男は「1 人暮し」 $3.5 \%$ にすぎず，「老夫婦暮し」 42\%である，これにたいして，女は「1人暮し」が多く $24.2 \%$ あり，「老夫婦暮し」は18\%にすぎない.「家族 同居」は男女差をみとめない。（表 2）

1977年の厚生行政基礎調査によると, 10大都市平均の 60 才以上高年者の「単独世帯」は男 $3.5 \%$, 女 $24 \%$ あ゙あ る. 本調査対象の世帯類型は全国大都市平均に近似す る.

別居家族があり116名 (56\%)，その1/3は「遠くに離え て住えでいる」. 別居家族があるものの63\%は仕送りを うける」,「遠くに住んでいる」家族からは仕送りをうけ ないものが多い. 
表 1 老年者調査の対象 一性別・年令別一

(守口)

\begin{tabular}{|c|c|c|c|c|c|c|c|c|c|c|}
\hline \multirow[b]{2}{*}{ 調査数 } & \multirow{2}{*}{$\frac{\text { 総 }}{209}$} & \multirow{2}{*}{$\frac{\text { 数 }}{100 \%}$} & \multicolumn{2}{|c|}{ 65才〜75才未満 } & \multicolumn{2}{|c|}{ 70才〜75才未满 } & \multicolumn{2}{|c|}{ 75才〜80才未満 } & \multicolumn{2}{|c|}{80 才以上 } \\
\hline & & & & 39.2 & & 24.9 & & 23.9 & 25 & 12.0 \\
\hline 男 & 86 & 100.0 & 34 & 39.5 & 20 & 23.3 & 24 & 27.9 & 8 & 9.3 \\
\hline 女 & 123 & 100.0 & 48 & 39.0 & 32 & 26.0 & 26 & 21.1 & 17 & 13.8 \\
\hline
\end{tabular}

表 2 老人の世帯類型 一性別・年令別一

(守口)

\begin{tabular}{|c|c|c|c|c|c|c|c|c|c|c|c|c|c|c|c|c|}
\hline & 総 & 数 & \multicolumn{2}{|r|}{ 男 } & \multicolumn{2}{|c|}{ 女 } & \multicolumn{2}{|c|}{ 65才 70才未満 } & \multicolumn{2}{|c|}{ 70才〜 75才未满 } & \multicolumn{2}{|c|}{ 75才 80才未莄 } & \multicolumn{2}{|c|}{80 才以上 } \\
\hline & & & 209 & 100.0 & $\begin{array}{r}\text { 名 } \\
86\end{array}$ & 100.0 & 123 & 100.0 & 82 & 100.0 & 52 & $100 \%$ & 50 & $100 . \%$ & 25 & $100 .{ }^{\%}$ \\
\hline 配 & あ & & 118 & 56.5 & 77 & 89.5 & 41 & 33.3 & 60 & 73.2 & 24 & 46.2 & 23 & 46.0 & 11 & 44.0 \\
\hline 偶 & な & & 91 & 43.5 & 9 & 10.5 & 82 & 66.7 & 22 & 26.8 & 28 & 53.9 & 27 & 54.0 & 14 & 56.0 \\
\hline \multicolumn{3}{|c|}{ 家族同居 } & 119 & 56.9 & 47 & 54.7 & 72 & 58.5 & 44 & 53.7 & 32 & 61.5 & 26 & 52.0 & 17 & 68.0 \\
\hline \multicolumn{3}{|c|}{ 老夫婦暮し } & 57 & 27.3 & 36 & 41.9 & 21 & 18.1 & 31 & 37.8 & 12 & 23.1 & 11 & 22.0 & 3 & 12.0 \\
\hline \multicolumn{3}{|c|}{ 一人暮し } & 33 & 15.8 & 3 & 3.5 & 30 & 24.4 & 7 & 8.5 & 8 & 15.4 & 13 & 26.0 & 5 & 20.0 \\
\hline
\end{tabular}

表 3 老人の日常生活能力 A D L

(守口)

\begin{tabular}{|c|c|c|c|c|c|c|c|c|c|c|c|c|c|c|}
\hline & 総 & 数 & \multicolumn{2}{|r|}{ 男 } & \multicolumn{2}{|r|}{ 女 } & \multicolumn{2}{|c|}{ 65すー 70才未满 } & \multicolumn{2}{|c|}{ 70才〜75や未满 } & \multicolumn{2}{|c|}{ 75才〜80才末渵 } & \multicolumn{2}{|c|}{80 才以上 } \\
\hline & 209 & $100 . \%$ & 86 & 100.0 & 123 & $100 \%$ & 82 & $100 . \%$ & 52 & $100 . \%$ & 50 & $100 . \%$ & 25 & 100.0 \\
\hline 全 介 助 & 6 & 2.9 & 3 & 3.5 & 3 & 2.4 & 2 & 2.4 & 1 & 1.9 & 2 & 4.0 & 1 & 4.0 \\
\hline 部分介助 & 5 & 2.4 & - & - & 5 & 4.1 & 2 & 2.4 & 2 & 3.9 & 1 & 2.0 & - & - \\
\hline 部分独立 & 28 & 13.4 & 9 & 10.5 & 19 & 15.4 & 8 & 9.8 & 7 & 13.5 & 5 & 10.0 & 8 & 32.0 \\
\hline 全 独 立 & 165 & 78.9 & 73 & 84.9 & 92 & 74.8 & 68 & 82.9 & 42 & 80.8 & 40 & 80.0 & 15 & 60.0 \\
\hline 無 回 答 & 5 & 2.4 & 1 & 1.2 & 4 & 0.3 & 2 & 2.4 & - & - & 2 & 4.0 & 1 & 4.0 \\
\hline
\end{tabular}

表 4 老人の日常生活

(守口)

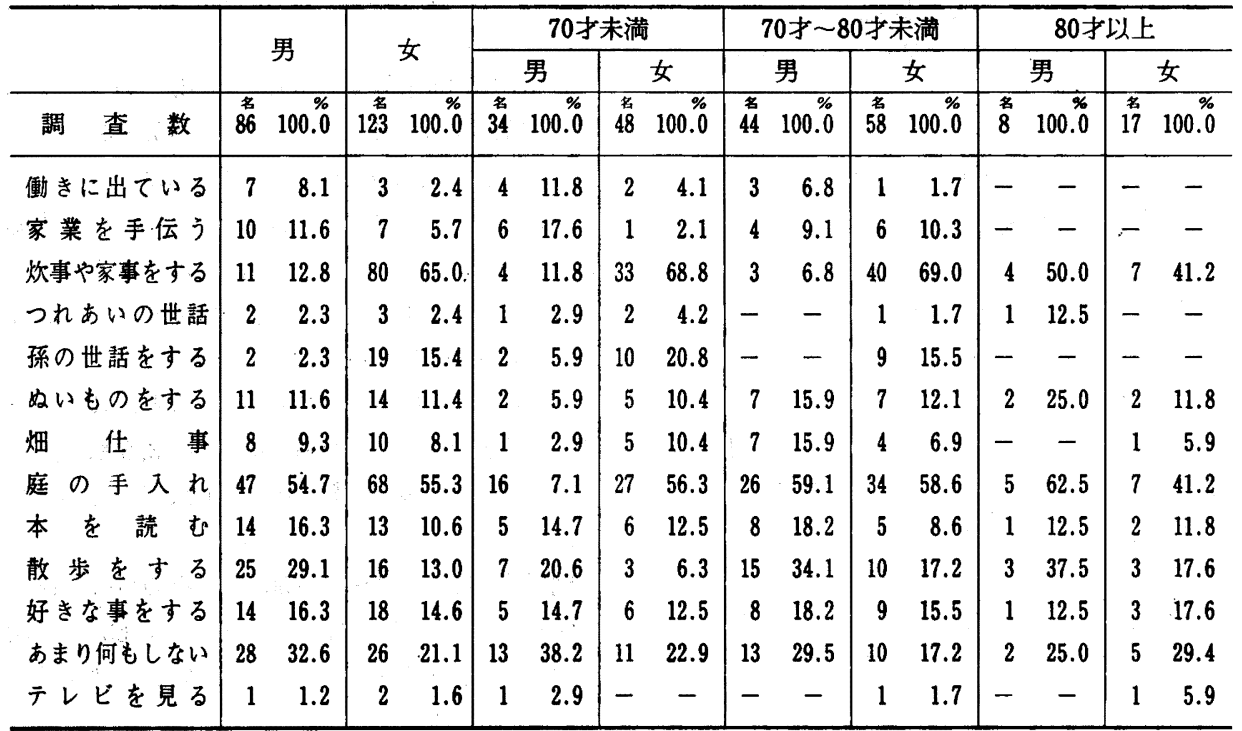




\section{3）年金および医丵保険加入状況}

年金の種類 : 老年者の経済生活は「年金」に負うとこ ろが大きい，何らかの年金をうけている者 182 名 (87.1 \%) である.その種類は厚生年金91名(43.5\%)，老令福 祉年金 56 名 (26.8\%), 遗族年金 9 名 (4.3\%), 恩給 4 名 (1.9\%) 等である. 生活保菱受給者 5 名 $(2.4 \%)$ であ る.

医療保険加入状況：国民健康保険加入者 127 名（60.8 \%) を占め, 被用者保險家族 57名 (27.3\%), 自費 4 名 (1.9\%) であり，性，年令による著差をみとめない.

\section{4) 日常生活能力 ADL}

老人自身の判断による ADLは，「自分でほとんどでき ないので助けてもらう必要がある (要全介助)」6名, $2.9 \%$ (男 3 名, $3.5 \%$ ，女 3 名，2.4\%). 「自分でもでき るが助けてもらう必要がある (要部分介助)」5名2.4\% (男なし，女 5 名，4.1\%). 「不自由なところるあるが自 分でできる (部分独立)」28名，13.4\%，(男 9 名, 10.5 \%，女19名，15.4\%).「不自由なところがなく自分でで きる (全独立)」165名, 78.9\%（男73名, 85\%, 女92名, 75\%) である.（表 3)

年令別にみると, 80才以上は79才以下にくらべて全独 立がやや少なく，部分独立がやや多く，加令とともに自 立能力の減弱をみとめる.

\section{2 生活檴造}

\section{1 ）日常生活}

老人の日常生活行為の種類は,「日頃, していること」 に対する回答では, 男の場合, 「庭いじり」55\%がもっと も多く，「散歩」27\%が上位を占め,つづいて「本を読
む」16\%，「好きなことをする」16\%である．

女は「炊事, 家事をする」65\%，「庭の手入れ」55\%が いずれも過半数を占め,つゔいて「あまり何むしない」 21\%,「孫の世話」15\%，「好きな事」15\%とつづく（表 4). 年令別：男, 60才台注「家業の手伝い」(18\%), 「働きに出る」(12\%) など,「働き」と関係するるのが あるが，70才以上，老令化するほど，「㗢き」から遠ざか り，「庭の手入れ」や「散歩する」「何もしない」などが 増える.女場合は，70才台までは，「炊事，家事」69 $\%$ ，「孫の世話」20\%なぞ，家庭内の「働き」に関係し， 「庭の手入れ」50\%強がつゔいている. 80才台になると 「働き」は少なくなり，「何もしない」「散歩」「すきな 事」が増える。

なお，生活行為を「働きごと」「家庭の仕事」「勝手な こと」の 3 種にまとめ, 重復回答を合せた累計を 100 と した百分比であらわすと，女は「家庭の仕事」58\%， 「働きでと」11\%，「睠手なこと」21\%にたいして，男は 「働きごと」25\%，「家庭仕事の」15\%，「勝手なこと」 60\%であり，半ばは無為・無聊をかこっているといえ る.

\section{2）食生活}

老人にとって食生活は楽しみでああり，関心が大き い.

主食：全員が米食であるが，1/3はパンを併食する.

副食物：「毎日食べる」と答えた食品は，野菜 (84.2\%) が最も多く，つづて海草 (54.6\%) が多く，動物性食 品は卵 (37.7\%), 魚 (32.7\%) 肉 $(20.2 \%)$ と分散して いる.これに対して「稀にしか食べない」食品はインス
表 5 副食物の種類

\begin{tabular}{|c|c|c|c|c|c|c|c|c|c|c|}
\hline & & & \multicolumn{4}{|c|}{ 毎日食べる食品 } & \multicolumn{4}{|c|}{ 稀にしか食べない食品 } \\
\hline & & & \multicolumn{2}{|r|}{ 男 } & \multicolumn{2}{|r|}{ 女 } & \multicolumn{2}{|c|}{ 男 } & \multicolumn{2}{|r|}{ 女 } \\
\hline 調 & 查 & 数 & 86 & $100 . \%$ & 123 & 100.0 & 86 & $100 . \%$ & 123 & $100 . \%$ \\
\hline & 魚 & & 34 & 39.5 & 34 & 27.6 & 12 & 14.0 & 14 & 11.4 \\
\hline & 肉 & & 17 & 19.8 & 25 & 20.3 & 17 & 19.8 & 30 & 24.4 \\
\hline & 卵 & & 38 & 44.2 & 40 & 32.5 & 10 & 11.6 & 33 & 26.8 \\
\hline 牛 & & 乳 & 31 & 36.0 & 30 & 24.4 & 42 & 48.8 & 75 & 60.1 \\
\hline バ & 夕 & - & 21 & 24.4 & 24 & 19.5 & 35 & 40.7 & 61 & 49.6 \\
\hline ハム & ・ソーセ & ージ & 4 & 4.7 & 9 & 7.3 & 36 & 41.9 & 63 & 51.2 \\
\hline カ & マホホ & $\sqsupset$ & 7 & 8.1 & 17 & 5.7 & 37 & 43.0 & 46 & 37.4 \\
\hline 野 & & 菜 & 73 & 84.9 & 103 & 83.7 & 2 & 2.3 & 4 & 3.3 \\
\hline 海 & & 草 & 39 & 45.3 & 74 & 60.2 & 7 & 8.1 & 6 & 4.9 \\
\hline イン & スタント & 食品 & 4 & 4.9 & 1 & 0.8 & 51 & 59.3 & 96 & 78.0 \\
\hline
\end{tabular}

\begin{tabular}{|c|c|c|c|}
\hline & 調 查 数 & 209 & 100.0 \\
\hline \multirow{4}{*}{$\begin{array}{l}\text { 常 } \\
\text { 住 } \\
\text { す } \\
\text { る } \\
\text { 室 }\end{array}$} & 3 畳 以下 & 10 & 4.8 \\
\hline & 4.5 & 35 & 16.8 \\
\hline & 6 & 136 & 65.0 \\
\hline & 8 骨 以上 & 17 & 8.1 \\
\hline \multirow{8}{*}{$\begin{array}{l}\text { 住 } \\
ま \\
\text { い } \\
に \\
\text { た } \\
\text { い } \\
す \\
\text { る } \\
\text { 要 } \\
\text { 望 }\end{array}$} & 要 望 あ ク & 108 & 51.7 \\
\hline & & & 100.0 \\
\hline & 庭がほ しい & 43 & 40.4 \\
\hline & 日当りのよい部屋ほしい & 42 & 39.6 \\
\hline & ひとりの部屋ほしい & 11 & 10.4 \\
\hline & 広い部屋ほしい & 10 & 9.3 \\
\hline & 静かな部屋ほしい & 10 & 9.3 \\
\hline & の & 5 & 4.6 \\
\hline
\end{tabular}


タント食品(71.0\%), 牛乳(55.9\%), 八ム, ソーセージ (47.6\%)，バター (46.7\%) である. 男は女に比べて, 魚, 牛乳が比較的多く, また女は牛乳，八ム, ソーセ一 ジを好まない傾向がある.すなわち米飯と一部パン併食 し，副食は野菜と卵，魚あるいは肉との組み合せによ り，女は牛乳の摄取が比較的少ないようである。（表 5 ）

食事の用意 : 女は $62 \%$ 汇自分でつくる」. 男はほとん ど家族がつくる $(85 \%)$ ，高令者ほど「家族がつくる」割 合が增える.「食事を作ってほしい」が 9 名あり，その うち 7 名は女である. とくに 1 人暮しの老女の食生活に 問題がありそうである.

3) 住生活と入浴

老人が主にいる部屋の広さは，4 畺半以下が $20 \% ， 6$ 畳が $2 / 3$. 住まいについて要望あるむの $52 \%$ ，そのうち「日 当りのよい部屋がほしい」40\%,「1人部屋がほしい」10 \%,「庭がほしい」40\%, 住居事情はよくない。（表 6 ）

当地法零細な住居が多く, 有数の過密居住地域であ る. 大気污染公害指定地域であり, また交通事故多発地 域である. これらの不良住環境は老人にしわよせられて おり，とくに住宅事情の改善を望むむのが比較的多い.

入浴：毎日入る (87名) 42\%，2 日に 1 回 (82名) 39 \%。週 2 回（21名）10\%。ただし週 1 回が 4 名（2\%） ある.

男，82才，老夫婦暮し，不整脈あり，松葉杖で歩く， 「3力月前に 1 回銭楊に行っただけ」という事例がある. ひとりくらし老人では, 入浴介助, 巡回入浴サービス, 自家用風呂の設置を望むむのがある.

\section{4) 人間関係}

家族との関係：問題があるるの 18 名 $(9 \%)$, うち 17 名 は女である.

近所とのつきあい: 近所つきあいしない 8 名，うち 7 名は女である。

老人クラブ：83\%が老人クラブに入っている.「老人 クラブに入っているが，集りに出かけない」と「老人ク ラブに入っていない」を合せると60名，29\%ある.

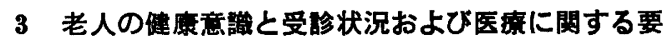 望事項}

1）健康意識：フンケート調査において「病気があ る」と答えたもの 92 名, 全体の $44.0 \%$,「健康といえぬ」 61名，29.2\%あり，ともに高令者にやや高率である。 た半数は「気にやむことがある」という(112名，53.6\%).

(表 7)

\section{2）アンケート铜查による愁訴}

アンケート調查により，何らかの愁訴があるもの73.7 \%あり. その内容は頭痛 (25\%), 不眠 (28\%), 物忘れ (35\%)，見えにくい(46\%)，聞こえにくい(34\%)，心 臓がわるい (23\%), 血圧が高い (30\%), 胸が階段で苦 しい (29\%), 便秘 (25\%), 夜間頻尿 ( 3 回以上, $26 \%$ ). 関節痛 $(47 \%)$ などの訴えの頻度が高い（表 8 )

女 (78.9\%) は男 $(66.3 \%)$ よりも愁訴を訴える割合 がやや高い，その内容は，男に比べて高率であるのは， 頭痛, 不眠, 消化器の訴元, 関節痛などであり, 男が女 に比べて高率な訴えは，物忘れ，ことばがーもれる，せ き，たんなどの呼吸器系の訴えである，心臟・循環器の 訴えは，男女間传有意差をみとめない。

\section{3) 受診状況}

「現在医者にかかっている」むのは154名. 受診率73.7 \%である(男79\%，女70\%)，75才以上の高令者は75才未 满よりも受診率がやや高い（表 9 ）

\section{4) 医痖に関する要望}

「病気を治してほしい」46名(22\%)，「尃門医に見て むらいたい」25名(12\%)「相談にのってくれる医者がほ しい」17名(8\%).「往診をしてほしい」13名(6.2\%), 「健康診断をしてほしい」27名 (1.3\%) など, 医師や医 療内容に関する要求をかなり出している。（表10）

また「はり，マッサージしてほしい」30名 (14\%) あ る.すなわち，受診率は70\%を超し，かなり高いが，医 療の質については満足していないものがかなりある.

「柬医者にかかりたい」24名 (12\%).「保健婦，看護婦 に来てほしい」11名（5\%）ある. 女は男に比べて「畨

表 7 老人の健康意識

(守口)

\begin{tabular}{|c|c|c|c|c|c|c|c|c|c|c|}
\hline & 総 & 数 & \multicolumn{2}{|c|}{ 男 } & \multicolumn{2}{|c|}{ 女 } & \multicolumn{2}{|c|}{ 75才未佩 } & \multicolumn{2}{|c|}{ 75才以上 } \\
\hline 調 査 数 & 209 & 100.0 & 86 & $100 . \%$ & 123 & $100 . \%$ & 134 & $100 . \%$ & 75 & $100 . \%$ \\
\hline 病気がある & 92 & 44.0 & 38 & 44.2 & 50 & 40.7 & 53 & 39.6 & 35 & 46.7 \\
\hline さほど健康でない & 61 & 29.2 & 23 & 26.7 & 35 & 28.5 & 35 & 26.1 & 23 & 30.7 \\
\hline 気にやむことがある & 112 & 53.6 & 45 & 52.3 & 67 & 54.5 & 72 & 53.7 & 40 & 53.3 \\
\hline
\end{tabular}


表 8 アンケート調査による老人の愁訴

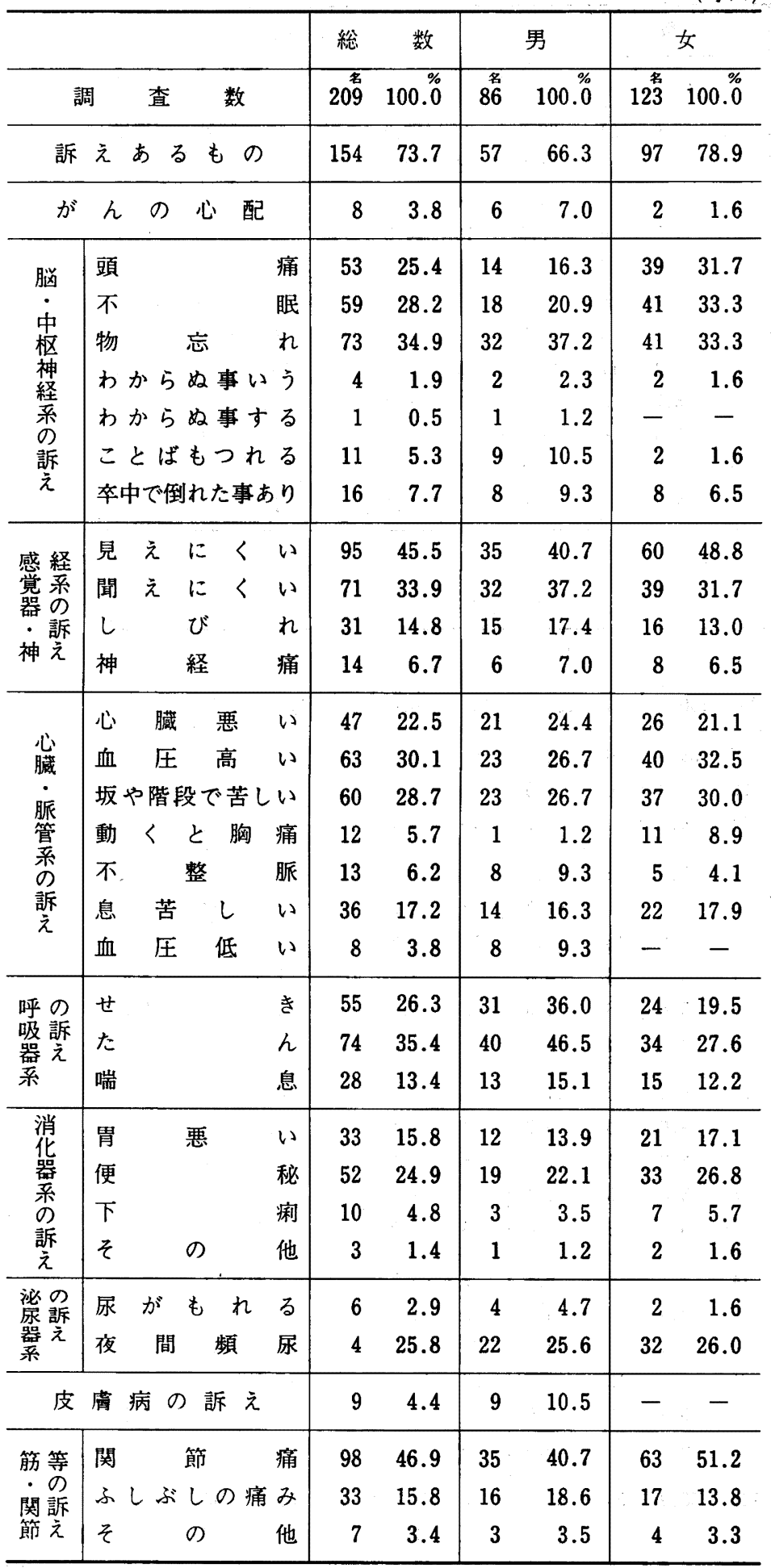

表 9 現在医師にかかっている (守口)

\begin{tabular}{c|rr}
\hline 総 数 & 154 & $(73.7)$ \\
\hline 男 & 68 & $(79.0)$ \\
女 & 86 & $(69.9)$ \\
\hline 70 才未満 & 56 & $(68.3)$ \\
70 75才未満 & 36 & $(67.2)$ \\
75 80才末満 & 42 & $(84.0)$ \\
80 才以 上 & 25 & $(80.0)$ \\
\hline
\end{tabular}

（）内は受診率 
表10 老人の医療に関する要望

(守口)

\begin{tabular}{|c|c|c|c|c|c|c|c|c|c|c|}
\hline & 総 & 数 & \multicolumn{2}{|r|}{ 男 } & \multicolumn{2}{|c|}{ 女 } & \multicolumn{2}{|c|}{ 75才未満 } & \multicolumn{2}{|c|}{ 75才以上 } \\
\hline & 209 & $100 . \%$ & 86 & 100.0 & 123 & 100.0 & 134 & $100 . \%$ & 75 & 100.0 \\
\hline 病気を治してほしい & 46 & 22.0 & 24 & 27.9 & 22 & 17.9 & 27 & 20.1 & 39 & 52.0 \\
\hline 健康診断してほしい & 27 & 12.9 & 12 & 14.0 & 15 & 12.2 & 15 & 11.2 & 12 & 16.0 \\
\hline 専門医に見てもらいたい & 25 & 12.0 & 11 & 12.8 & 14 & 11.4 & 16 & 11.9 & 9 & 12.0 \\
\hline 歯医者にかかりたい & 24 & 11.5 & 6 & 7.0 & 18 & 14.6 & 16 & 11.9 & 8 & 10.7 \\
\hline 相談にのってくれる医者がほしい & 17 & 8.1 & 7 & 8.1 & 10 & 8.1 & 11 & 8.2 & 6 & 8.0 \\
\hline 往 診してて ほ し い & 13 & 6.2 & 4 & 4.7 & 9 & 7.3 & 10 & 7.5 & 3 & 4.0 \\
\hline 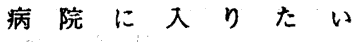 & 2 & 1.0 & 2 & 2.3 & - & Q. बह & 1 & 0.7 & 1 & 1.3 \\
\hline ハリ・マッサージをしてほしい & 30 & 14.4 & 11 & 12.8 & 19 & 15.4 & 20 & 14.9 & 10 & 13.3 \\
\hline あうメガネがほしい & 14 & 6.7 & 3 & 3.5 & 11 & 8.9 & 9 & 6.7 & 5 & 6.7 \\
\hline 保健婦 - 看護婦の訪問希望 & 11 & 5.3 & 6 & 7.0 & 5 & 4.1 & 5 & 3.7 & 6 & 8.0 \\
\hline ヘルパーにきてほしい & 8 & 3.8 & 3 & 1.4 & 5 & 2.4 & 3 & 2.2 & 5 & 6.7 \\
\hline 温泉 へ行きたい & 57 & 27.3 & 22 & 25.6 & 35 & 28.4 & 32 & 2.9 & 25 & 33.0 \\
\hline
\end{tabular}

表11老人の意識と望み

(守口)

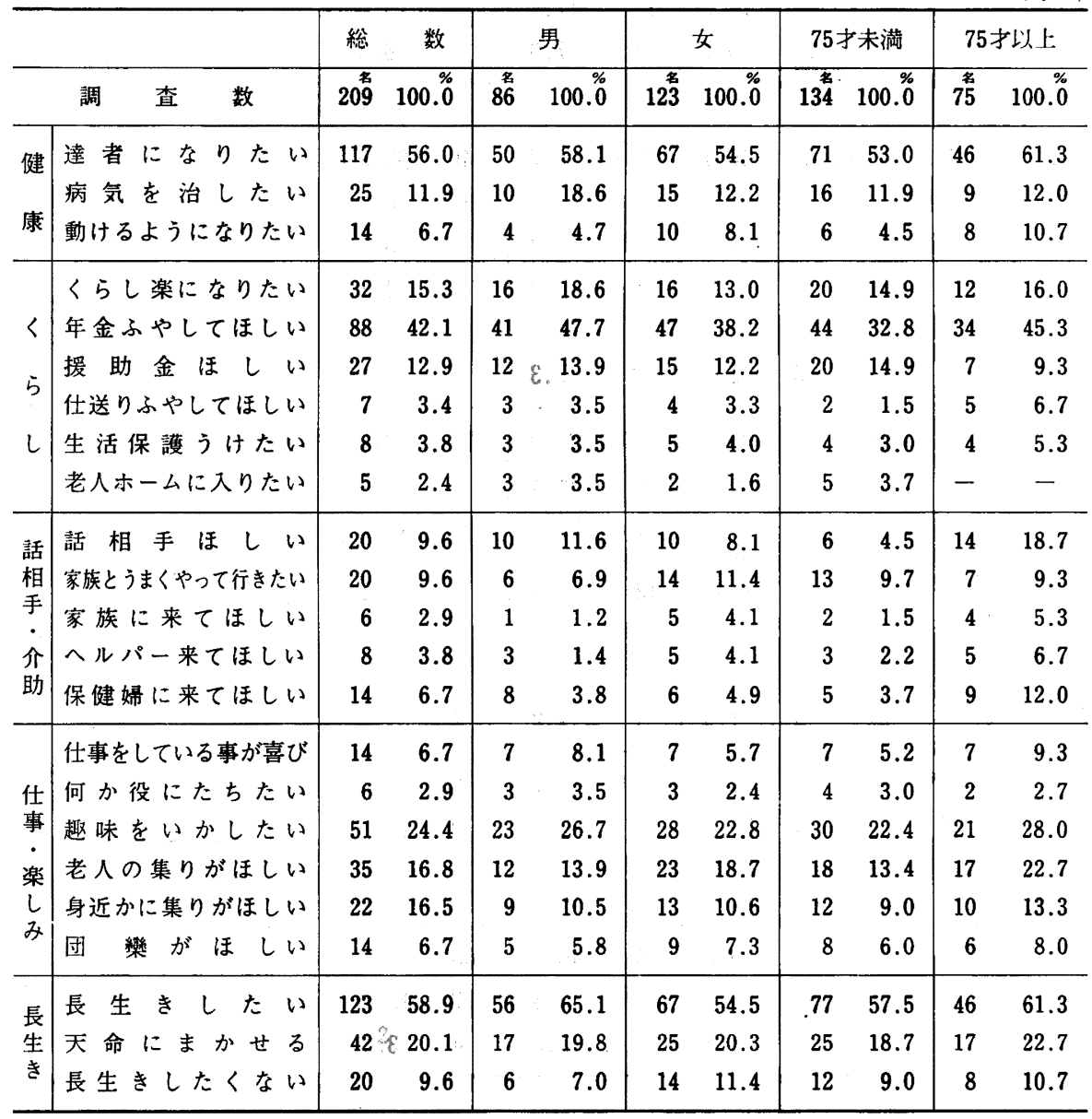


医者にかかりたい」「あう眼鏡がほしい」どの訴え率が やや高い.なお「温泉に行きたい」ものが57名 (27\%)， とくに75才以上の高令老人では高率 (33\%) であり,リ クレェションを求めている.

\section{4 老人の忷みと望み}

老化にともなう体力の低下，疾病，心身障害による悩 みあるいは老人の心理，意識と現実とのギャップによる 不満, 苦絁からの解放こそが, 老人問題における緊急な 課題であり，老人の意識と要望するむとを正しく把握す る必要がある(表11).

\section{1) 健康について}

まず半数以上が「達者になりたい」とのぞんでいる (120名，57\%)。一部は「病気を治したい」「働けるよう になりたい」という．前述のごとく，医療についてはか なりの要求があるようである.

\section{2) くらしについて}

半数近く (44\%) が「年金をふやしてほしい」という. 「くらしが楽になりたい」32名（15\%)，「くらしに援助 金ほしい27名 (13\%),「生活保護をうけたい」8名（4 \%)など, 老人のくらしはけっして楽でなく, 扶助の強 化をもとめている.なお「老人ホームに入りたい」5名 (2.4\%) ある.

\section{3) 話相手と介助について}

「話相手がほしい」「家族とうまくやって行きたい」 また保健婦, 一ルパー, 家族にきてほしいといい，孤独 感をかこち, 介助をもとめている。

\section{4) 楽しみをもとめて}

当地域の老人は，とくに男の場合，「働き」に類する 生活行動が少ない.ひいては「仕事をすることが喜び」 14名 (7\%),「何か役にたちたい」6名 (3\%),「社会
奉仕したい」22名（11\%）という，また「趣味をいかし たい」51名 (24\%)，また「老人の集りがほしい」35名 (17\%)「身近かに集りの場所ほしい」22名（11\%）「娛 楽がほしい」14名（7\%）など，楽しみをもとめている あのが多い.

\section{5 ) 長生きについて}

過半数は「長生きしたい」というが，「天命にまかせ る」20\%あり，また10\%は「長生きしたくない」とい う.「長生きしたくない」という老人は，80才以上の高令 者のほかに, ひとり暮し, 病気がある, 気にやむととが ある，家族内にトラブルがあるなど，何らかの問題をか かえている傾向がある.

\section{6) とくに望んでいること（表12）}

重ねて，「とくに望んでいる」ことを尋祆ると，「病気 を治したい」25名 (12\%) 「家族とうまくやって行きた い」20名 (10\%)「年金をふやしてほしい」8名 (4\%). 「老人医療費の負担がかから妨よにしてほしい」6名 （3\%）などの回答があった.これらは切実な要求とし てうけとめる必要があろう.

\section{II 都市老人の健康診断結果}

前述のごとく抽出した 209 名中, 健康診断をうけた者 は175名（男67名，女108名). 受診率83.7\%である。

健康診断項目は, 予診, 主訴, 既往症, 家族歴等, 一 般理学的検査, 心電図, 尿検査, 血液検査 (全血比重, 臨床化学検査) であり, 循環器系の検診に主眼をおい た. 血圧は30分以上安静後, 坐位, 心臓高で測定した. 採血は原則として食後 2 時間以上経ておこなった。

\section{1 病㲤}

受診者175名のうち, 何らかの病訴があるものは168名， 全体の $96 \%$ を占め，まったく訴えのなかった者 7 名，4

\begin{tabular}{|c|c|c|c|c|c|c|}
\hline & 総 & 数 & & 男 & & 女 \\
\hline 調 查 数 & 209 & 100.0 & 86 & $100 \%$ & 123 & 100.0 \\
\hline 病気を治したい & 25 & 11.9 & 10 & 11.6 & 15 & 12.2 \\
\hline 健 康 と 長 寿 & 17 & 8.1 & 6 & 6.9 & 11 & 8.9 \\
\hline 医療费のかからぬよう & 6 & 2.9 & 0 & - & 6 & 4.8 \\
\hline 家族とうまくやっていきたい & 20 & 9.6 & 6 & 6.9 & 14 & 11.4 \\
\hline 仕事をしている事が喜び & 14 & 6.7 & 7 & 8.1 & 7 & 5.7 \\
\hline 金 & 8 & 3.8 & 6 & 6.9 & 2 & 1.6 \\
\hline 社会福 & 6 & 2.9 & 4 & 4.7 & 2 & 1.6 \\
\hline 权たきり老人優遇 & 3 & 1.4 & 0 & - & 3 & 2.4 \\
\hline 老人会の 集 $い$ & 5 & 2.4 & 3 & 3.5 & 2 & 1.6 \\
\hline 何か役に立つ事をしたい & 6 & 2.9 & 3 & 3.5 & 3 & 2.4 \\
\hline 遊び事をしたい。 & 3 & 1.4 & 3 & 3.5 & - & - \\
\hline 若い人と変わらぬ様 & 3 & 1.4 & 3 & 3.5 & - & - \\
\hline あまり希望もてない & 5 & 2.4 & 5 & 5.8 & - & - \\
\hline
\end{tabular}


\%にすぎない，80才以上，(26名）は100\%である。（表

13)

病訴の種類と多様性 : 愁訴の累計は 720,1 人平均 4.1 件の病訴がある計算になり，各種の病訴を重複して訴方 で்ことを示している.

病訴の種類 : 頻度の高い病訴の種類をあげと, 便秘 (58名，33\%) と腰痛 (56名，32\%), 見えにくい(51名， 29\%)がもっとも多く，ねむりにくい(47名27\%), 血圧 が高い (45名, 26\%)，たん (44名，25\%)，ふしぶしが 痛む (41名，23\%)，咳 (39名，22\%)，聞こえにくい(36 名, 21\%), 足が不自由 (36名, 21\%), 坂や階段で苦し

\begin{tabular}{|c|c|c|c|c|c|c|}
\hline !13 老 & & & & & & 守下 \\
\hline & & 数 & & 男 & & 女 \\
\hline 受 䛦 者 数 & & 100.0 & 67 & 100.0 & 108 & 100.0 \\
\hline 斯え え & 168 & 96.0 & 63 & 94.0 & 105 & 97.2 \\
\hline 脑・中枢神経系の訴え & 111 & 63.4 & 40 & 59.7 & 71 & 65.7 \\
\hline & 30 & 17.1 & 8 & 11.6 & 22 & 20.4 \\
\hline のほ せ易い & 24 & 13.7 & 8 & 11.6 & 16 & 14.8 \\
\hline ねむりにくい & 47 & 26.9 & 15 & 21.7 & 32 & 29.6 \\
\hline 物忘れひとい & 13 & 7.4 & 6 & 8.7 & 7 & 6.5 \\
\hline 当葉のもつれ & 11 & 6.3 & 6 & 8.7 & $\mathbf{5}$ & 4.6 \\
\hline 感光器の訴え & & & & & & \\
\hline 見えにくい & 51 & 29.1 & 16 & 23.9 & 35 & 32.4 \\
\hline 開こえにくい & 36 & 20.6 & 11 & 16.9 & 25 & 23.1 \\
\hline 心臟・脈管系の訴え & 75 & 42.9 & 25 & 37.3 & 50 & 46.3 \\
\hline 血圧が高 & 45 & 25.7 & 16 & 23.2 & 29 & 26.9 \\
\hline 趿 悸 うつ & 32 & 18.3 & 10 & 14.5 & 22 & 20.4 \\
\hline 息 切 れする & 31 & 17.7 & 11 & 15.9 & 20 & 18.5 \\
\hline 坂や階段で苦しくなる & 32 & 18.3 & 9 & 13.0 & 23 & 21.3 \\
\hline 服 が と & 4 & 2.3 & - & - & 4 & 3.7 \\
\hline 呼吸器系の訴え & 56 & 32.0 & 9 & 43.3 & 27 & 25.0 \\
\hline . & 39 & 22.3 & 20 & 29.5 & 19 & 17.6 \\
\hline た & 44 & 25.1 & 21 & 30.5 & 23 & 21.3 \\
\hline 喘 & 11 & 6.3 & 6 & 8.5 & 5 & 4.6 \\
\hline 消化器系の訴え & 78 & 44.6 & 23 & 4.3 & 55 & 50.9 \\
\hline 胃 が 悪 $い$ & 25 & 14.3 & 7 & 10.5 & 18 & 16.7 \\
\hline 下沘し易 い & 9 & 5.0 & 1 & 1.5 & 8 & 7.4 \\
\hline 便 & 58 & 33.1 & 15 & 21.7 & 43 & 39.8 \\
\hline 食 欲 & 4 & 2.3 & - & - & 4 & 3.7 \\
\hline 夜間 & 31. & 17. & 8 & 12.0 & 23 & 21.3 \\
\hline 筀・関節·運動器系の培え & 98 & 56. & 35 & 52.2 & 63 & 58.3 \\
\hline ふしぷしが痛む & 41 & 23.4 & 14 & 20.3 & 27 & 25.0 \\
\hline 腰 & 56 & 32.0 & 15 & 21.7 & 41 & 37.0 \\
\hline 足 が不自 由 & 36 & 20.6 & 18 & 26.1 & 18 & 16.7 \\
\hline 手 が不自 由 & 10 & 5.7 & 7 & 10.1 & 3 & 2.8 \\
\hline 果部 & 72 & 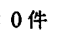 & & 48 件 & & \\
\hline 1 人当り病䉼数 & & .1 & & 3.7 & & 4.4 \\
\hline
\end{tabular}

くなる (32名, 18\%)，息切れがする(31名，18.\%)，動 悸うつ(32名, 18\%) 夜間頻尿 (3 回以上, 31名, 18\%) 頭 痛 (30名，17\%）などが続く．物忘れがひどい（13名， $7 \%)$ ，ことばがもつれる(11名，6\%)，(11名，6\%)， 手が不自由 (10名, $6 \%$ ), 脈がとぶ (4名, 2\%), な ぞは，老人の病訴としてみのがせない。

大分類でまとめると, 脳・中枢神経系の訴え(111名, 63\%) がもっとも多く, 筋・関節・運動器系の訴え (98 名, 56\%), 消化器系の訴元 (78名, 45\%), 循環器系の 訴元 (75名, 43\%), 呼吸器系の訴光 (56名, 32\%), が 順次, 続 $<$.

すなわち，視力低下，聴力低下のほかに，筇・関節・ 運動器系の訴元, 脳・中枢神経系の訴元, 循環器系の訴 えなどが多い。

性別比較：全体の病訴の率には差をみとめないが，病 訴の種類には若干の男女差がある。男は呼吸器系の訴え が多く, 女は消化器系の訴光 (特に便秘), 腰痛, 夜間頻 尿（3 回以上）の訴えなどが多い.

年令別比較：80才以上は全員が病訴をもっている. 見 えにくい, 聞こえにくい, 心臓循環器系の訴え, 腰痛, 夜間頻尿などは，高令の老人など高率である傾向をみと める.

\section{2 有所見者}

健康診断の結果, 受診者 175 名のうち，169名，全体の 96.6\%に何らかの異常所見をみとめている. 異常所見を 概祖国際疾病分類 (1979) 亿準じてまとめると, 表14の ごとくである.

1）疾病大分颣：循環器系の異常所見を認めるものが 全体の $60.6 \%$ むり，むっとも高率である、神経系およ び感鸴器系の異常所見をみとめるもの $41.1 \%$ が，これに 次ぐ．筋・関節および結合織系の異常 $33.7 \%$, 泌尿器系 の異常18.9\%, 呼吸器系の異常17.1\%とつゔく.

2 ）異常所見または疾病の種類：「心電困異常あり」 83名, 有所見率 $47.4 \%$, 半数に近い(その内容は後述). つづいて高血圧 (73名，41.7\%), 腰痛 (35名20\%) など 茂比較的多い。つゔいて，白内障 (29名，16.6\%)，夜間 頻尿（3回以上, 28名, 16\%), 難聴 (27名, 15.4\%), 神経痛 (35名, 14.3\%), 四肢運動障害 (23名, 13.1\%), 気管支炎 (18名，10.3\%）などが10\%以上.つゔいて喘 息 (11名, 6.3\%)，負血 (11名，6.3\%)，糖尿 (10名, $5.7 \%)$, 関節障害 ( 9 名, $5.1 \%$ ), 卒中後遗症 ( 8 名, 4.6\%) などである. その他は表14のごとくである.

尿検查成績：ウロウリテックス試験紙による検尿結 果, 蛋白陽性 $(+)$ 以上 15 名, $8.6 \%$, 性差は見られない が，80才以上に高率である．尿糖陽性20名，11.4\%であ 
表14 老人健康診断結果 一異常所見・疾病分類一

(守口)

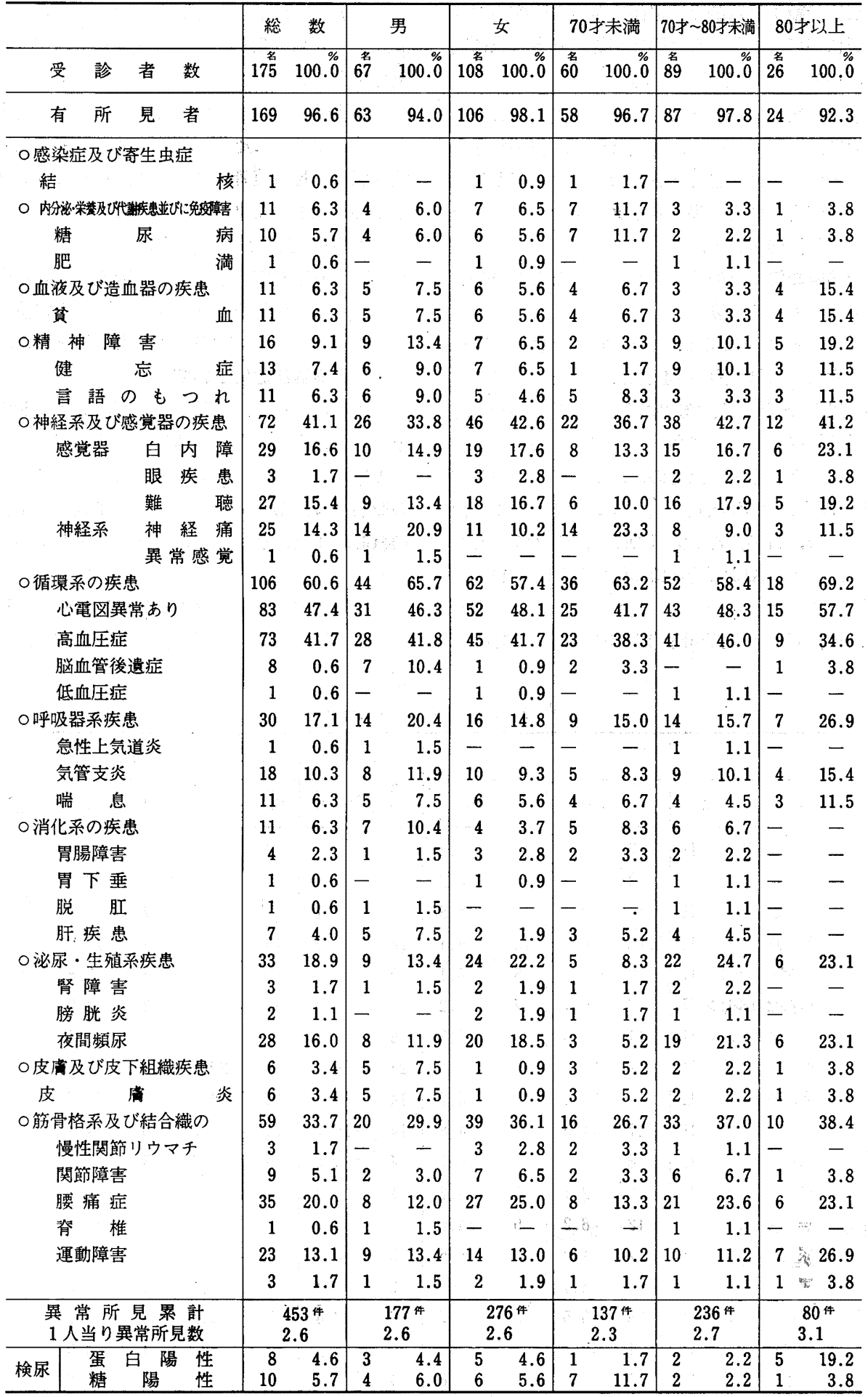


り，80才以上に高率である.

3）男女別比男は脳血管損傷後遺症と肝疾患が女 よりも有意に高率であり，女㴗痛が男よりも有意に高 率である. (各々，危険率 $5 \%$ 以下)

4）年令別比校：加令とともに有病率が高くなる傾向 があるむのは, 難聴. 白内障, 心電図異常, 夜間頻尿, 健忘症，ことばもつれなどである．なお，80才以上で は, 四肢運動障害, 筫血, 脚ブロック，喘息, 蛋白尿な ぞが高率となる傾向がある。

5）血液検查成縝：血液検查をおこなったもの146名， 受診者の $83.4 \%$ であ(表15).

全血比重：硫酸銅法汇よる．低比重者は（男1.051以 下）1名，女（1.048以下）が 4 名 $2.7 \%$ あったた. うち 4 名は75才以上の高令者7.8\%であり, 高率傾向である. 臨床化学的検查：異常值<各々下記（）の数値(註) より以上をた以下>を示したものは，中性脂肪高值(156

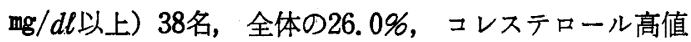
$(276 \mathrm{mg} / \mathrm{dl}$ 以上), 11名, $7.5 \%, \mathrm{LDH}$ 高値 $(276 \mathrm{U} / \mathrm{L}$ 以 上）28名, 19.2\%, ALP 高值 (13.3KAU以上), 14名, $9.6 \%$ ，血清鉄低值（男 $80 \mathrm{mg} / d l$ 末満，女 $60 \mathrm{mg} / d l$ 未満） 18 名, $12.3 \%$, K高值 $(5.7 \mathrm{mEg} / \mathrm{L}$ 以上) 17 名， $11.6 \%$,
無機燐低值 $(2.25 \mathrm{mg} / d \ell$ 末満) 12 名, $8.2 \%$, 尿索窒索高值 (22mg/dl以上) 7 名, $4.8 \%$, クレアチニン高値 $(15 \mathrm{mg} /$ $d \ell$ 以上) 8 名, $5.5 \%$, 総ビリルビン高値 $(1.1 \mathrm{mg} / d \ell$ 以 上） 7 名，4.\%などである.

性別比較 : 男は女に比べて無機燐高値者が高率の傾向 があり，女は男に比べて，コレステロール高值者，血清 鉄低值者， $\mathrm{K}$ 高值者が高率の傾向がある（危険率 $5 \%$ 以 下). 75才以上は75才未満に比べてクレアチニン高值者が 高率である(危険率 $5 \%$ 以下).

註：血液臨床化学検查は大阪血清微生物研究所传 頼した.「異常値」は同研究所の「正常値」の10\%増 よりも高値をたは10\%減よりも低值とした。

\section{3 㡒環器疾㭧について}

健康診断の結果, 循環器系の有所見率が60\%であり, 予想以上の高率であった(衰14)．その所見を分析すると

1 ）心园图異常所見：心電図供異常所見をみとめたも の83名 (47.4\%) あり, 受診者の半数近くにみとめた (表16)。 また，加令之共に異常所見率が上昇する傾向が ある.

心電四異常所見の内容 : ST, T 異常32名, 18.3\%にみ とめた. V5-6ST低下がもっとも多く30名, 被検者総数

表15 血液臨床化学検查結果

\begin{tabular}{|c|c|c|c|c|c|c|c|c|c|c|c|c|}
\hline \multirow[b]{2}{*}{ 検 } & \multirow[b]{2}{*}{ 查 } & \multirow[b]{2}{*}{ 数 } & \multirow{2}{*}{$\begin{array}{c}\text { 総 } \\
146\end{array}$} & \multirow{2}{*}{$\frac{\text { 数 }}{100 . \%}$} & \multicolumn{2}{|c|}{ 男 } & \multicolumn{2}{|c|}{ 女 } & \multicolumn{2}{|c|}{ 75才未満 } & \multicolumn{2}{|c|}{ 75才以上 } \\
\hline & & & & & 62 & 100.0 & 84 & $100 . \%$ & 95 & $100 . \%$ & 51 & $100 . \%$ \\
\hline G $O$ & & $\mathrm{H}$ & 2 & 1.4 & 2 & 3.2 & - & - & 2 & 2.1 & - & - \\
\hline$G \quad P$ & & $\mathrm{H}$ & 3 & 2.1 & 3 & 4.8 & - & - & 2 & 3.6 & 1 & 2.0 \\
\hline A L & & $\mathrm{H}$ & 14 & 9.6 & 3 & 4.8 & 11 & 13.1 & 7 & 7.4 & 7 & 13.7 \\
\hline L D & $\mathrm{H}$ & $\mathrm{H}$ & 28 & 19.2 & 10 & 16.1 & 18 & 21.4 & 19 & 20.0 & 9 & 17.7 \\
\hline 総ビリ & ルビン & $\mathrm{H}$ & 7 & 4.8 & 5 & 8.1 & 2 & 2.4 & 3 & 3.2 & 4 & 7.8 \\
\hline 直接ビ & リルビン & ン $\mathrm{H}$ & 2 & 1.4 & 2 & 3.2 & - & - & - & - & 2 & 3.9 \\
\hline コレス & テロロール & $2 \mathrm{H}$ & 11 & 7.5 & 2. & 3.2 & 9 & 10.7 & 9 & 9.5 & 2 & 3.9 \\
\hline 中性脂 & & $\mathrm{H}$ & 38 & 26.0 & 17 & 27.4 & 21 & 25.0 & 28 & 29.5 & 10 & 19.6 \\
\hline 血 清 & 鉄 & $\mathrm{L}$ & 18 & 12.3 & 4 & 6.5 & 14 & 16.7 & 10 & 10.5 & 8 & 15.7 \\
\hline $\mathrm{K}$ & & $\mathrm{H}$ & 17 & 11.6 & 3 & 4.8 & 14 & 16.7 & 11 & 11.6 & 6 & 11.8 \\
\hline $\mathrm{c} \ell$ & & L & 8 & 5.5 & 4 & 6.5 & 4 & 4.8 & 5 & 5.3 & 3 & 5.9 \\
\hline $\mathrm{C} \mathrm{a}$ & & $\mathrm{L}$ & 3 & 2.1 & 2 & 3.2 & 1 & 1.2 & 2 & 2.1 & 1 & 2.0 \\
\hline 無 機 & & $\mathrm{L}$ & 12 & 8.2 & 9 & 14.5 & 3 & 3.6 & 5 & 5.3 & 7 & 13.7 \\
\hline 尿紊空 & & $\mathrm{H}$ & 7 & 4.8 & 4 & 6.5 & 3 & 3.6 & 3 & 3.2 & 4 & 7.8 \\
\hline 尿 & 酸 & $\mathrm{H}$ & 2 & 1.4 & - & - & 2 & 2.4 & 1 & 1.1 & 1 & 2.0 \\
\hline クレ户 & チニン & $\mathrm{H}$ & 8 & 5.5 & 6 & 9.7 & 2 & 2.4 & 2 & 2.1 & 6 & 11.8 \\
\hline アルフ & ガミン & $\mathrm{L}$ & 1 & 0.7 & 1 & 1.6 & - & - & - & - & 1 & 2.0 \\
\hline 全血上 & & $\mathrm{L}$ & 5 & 3.4 & 1 & 1.6 & 4 & 4.8 & 1 & 1.1 & 4 & 7.8 \\
\hline
\end{tabular}

（註 $\mathrm{H}$ : 基準値より高偡者、 $\mathrm{L}$ ：基準值より低值者、 $\mathrm{Na}$ 、総蛋白、異常低值者なし） 
表16 心電図異常所見

(守口)

\begin{tabular}{|c|c|c|c|c|c|c|c|c|c|c|c|c|}
\hline & 総 & & & 男 & & 女 & & 未満 & 70 才 & 抹満 & & 以上 \\
\hline 検 查 数 & 175 & $100 . \%$ & 67 & $100 . \%$ & 108 & 100.0 & 60 & $100 . \%$ & 89 & 100.0 & 26 & 100.0 \\
\hline 心電図異常あり & 83 & 47.4 & 31 & 46.3 & 52 & 48.1 & 25 & 41.7 & 43 & 48.3 & 15 & 57.7 \\
\hline 心 筋 硬 塞 & 3 & 1.7 & 2 & 3.0 & 1 & 0.9 & 1 & 1.7 & 1 & 1.1 & 1 & 3.8 \\
\hline 心内膜下硬塞 & 1 & 0.6 & - & - & 1 & 0.9 & - & - & 1 & 1.1 & - & - \\
\hline$S T \cdot T$ 異常 & 32 & 18.3 & 6 & 9.1 & 26 & 24.1 & 12 & 20.0 & 16 & 18.0 & 4 & 15.3 \\
\hline$V_{4-6} T$ 逆転 & 2 & 1.2 & 1 & 1.5 & 1 & 0.9 & 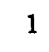 & 1.7 & r & 1.1 & - & - \\
\hline$V_{5-6} S T$ 低下 & 30 & 17.1 & 4 & 6.0 & 26 & 24.0 & 11 & 18.3 & 16 & 18.0 & 3 & 11.5 \\
\hline$V_{1-3} S T$ 上昇 & 1 & 0.6 & 1 & 1.5 & - & - & - & - & - & - & 1 & 3.8 \\
\hline 脚 ブロック & 11 & 6.3 & 8 & 11.9 & 3 & 2.8 & 1 & 1.7 & 6 & 6.7 & 4 & 15.4 \\
\hline 左肢前枝ブロック & 1 & 0.6 & 1 & 1.5 & - & - & - & - & - & - & 1 & 3.8 \\
\hline 整 & 8 & 4.6 & 7 & 10.4 & 1 & 0.9 & 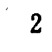 & 3.3 & 4 & 4.5 & 2 & 7.7 \\
\hline 脈 & 4 & 2.3 & 2 & 3.0 & 2 & 1.9 & - & - & 4 & 4.5 & - & - \\
\hline 脈 & 1 & 0.6 & - & - & 1 & 0.9 & 1 & 1.7 & - & - & - & - \\
\hline 大 & 18 & 10.3 & 6 & 9.0 & 12 & 11.1 & 5 & 8.3 & 11 & 12.4 & 2 & 7.7 \\
\hline 左 房 肥 大 & 6 & 3.4 & 2 & 3.0 & 4 & 3.7 & 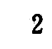 & 3.3 & 2 & 2.2 & 2 & 7.7 \\
\hline 右 房 肥大 & 1 & 0.6 & - & - & 1 & 0.9 & 1 & 1.7 & - & - & - & - \\
\hline 低 電 位 差 & 7 & 4.0 & 2 & 3.0 & 5 & 4.6 & 2 & 3.3 & 3 & 3.4 & 2 & 7.7 \\
\hline
\end{tabular}

表17 高血圧症と心電龱異常所見

(守口)

\begin{tabular}{|c|c|c|c|c|c|c|c|c|c|c|c|c|c|c|}
\hline & 総 数 & $\begin{array}{l}\text { 心電图 } \\
\text { 異常ちり }\end{array}$ & 心䬱硬塞 & $\begin{array}{l}\mathrm{V} 5-6 \\
\text { T逆転 }\end{array}$ & $\begin{array}{l}V_{5-6} \\
\text { S T低下 }\end{array}$ & $\begin{array}{l}\mathrm{V}_{1-3} \\
\mathrm{ST} \text { 上开 }\end{array}$ & 虾フロック & 不整脈 & 徐 脈 & 頻 脈 & 心肥大 & 左房肥大 & 右原肥大 & 低電位差 \\
\hline \multirow{2}{*}{ 高血圧症 } & 73 名 & 42 & 1 & - & 13 & - & 6 & 5 & 2 & - & 13 & 4 & - & 2 \\
\hline & $100.0 \%$ & 57.5 & 1.4 & - & 17.8 & - & 8.2 & 6.9 & 2.7 & - & 17.8 & 5.5 & - & 2.7 \\
\hline \multirow{2}{*}{ 非高血圧应 } & 102 名 & 41 & 2 & 1 & 17 & 1 & 5 & 3 & 2 & 1 & 5 & 2 & 1 & 5 \\
\hline & $100.0 \%$ & 40.2 & 40.2 & 2.0 & 16.7 & 1.0 & 4.9 & 2.9 & 2.0 & 1.0 & 4.9 & 2.0 & 1.0 & 4.9 \\
\hline
\end{tabular}

の $17.1 \%$ ，心電図異常所見者の $36.1 \%$ にみとめた。つ いで心肥大 18 名, $10.3 \%$, 脚ブロック 11 名, $6.3 \%$, 不 整脈 8 名（心房細動 2 名，期外収縮 6 名)，4.6\%, 低電 位差 7 名, $4.0 \%$, 左房肥大 6 名, $3.4 \%$, 徐脈 4 名, $2.3 \%$, 心筋梗塞 3 名, $1.7 \%$, V3-6T逆転, $\mathrm{V}_{3}-{ }_{5} \mathrm{ST}$ 上 昇, 頻脈, 左房肥大, 各々 1 名ある.

性別比較：男では女よりも有意に高率な異常所見は, 脚ブロック $(Z=2.135)$ と不整脈 $(Z=2.242)$ であ る(ともに危険率 $5 \%$ 以下で有意差)，女が男よりも有意 に高率な異常所見は $\mathrm{V}_{5}{ }_{6}{ }_{6} \mathrm{ST}$ 低下（危険率 $1 \%$ 以下）で ある.

年令別比較 : 脚ブロックは加令とともに高率となる傾 向がある.

\section{2 ) 高血圧症}

最高血圧 $160 \mathrm{mgHg}$ ，または最低血圧 $95 \mathrm{mgHg}$ 以上を高血 圧症とした. 受診者175名中73名(36\%) を高血圧症と判 定した。（表14）

高血圧症と心電図異常 : 何らかの心電図異常を認めた
者は，高血圧者では57.0\%，非高血圧者36.3\%よりも高 率の傾向である（有意差ではない）(表17). とくに心電 図，心肥大の所見は高血圧者 (17.8\%) 渄高血圧者 (4.9\%) よりも有意に高率である（危険率 $1 \%$ 以下).

高血圧症と血液臨床化学的所見：高血圧者と非高血圧 症者の間に有意差を認めない.（表18）

\section{3 ）心電図異常と血液臨床化学検查所見}

心電図異常をみとめたものは心電図異常をみとめなか った者に比べて，中性脂肪高值者が有意に高率である. $\mathrm{V}_{5}{ }_{6} \mathrm{ST}$ 低下 30 名中 10 名, 心肥大 18 名中 8 名, 脚ブロッ ク11名中 4 名が中性脂肪高值者であった.コレステロー ルについては心電図異常をみとめた者は，心電図異常を みとめなかった者に比べて、コレステロール高値者が高 率であるが，有意差ではない（表19）

\section{4 健康診断㲤後措置判定区分と受彭状況}

老人健康診断による有所見者 169 名について事後措置 を下記のごとく判定した。（表20）
A. 治療を要する者113名 (64.6\%) 
表18 高血圧症の臨床化学検査結果

\begin{tabular}{|c|c|c|c|c|c|}
\hline \multirow[b]{2}{*}{ 検 } & \multirow[b]{2}{*}{ 数 } & \multicolumn{2}{|c|}{ 高血圧＼cjkstart症 } & \multicolumn{2}{|c|}{ 非高血圧症 } \\
\hline & & & 100.0 & 86 & 100.0 \\
\hline $\begin{array}{lll}\text { G } & \mathrm{O} & \mathrm{T}\end{array}$ & $\mathrm{H}$ & 2 & 3.3 & - & - \\
\hline G $\quad P \quad T$ & $\mathrm{H}$ & 2 & 3.3 & 1 & 1.2 \\
\hline A $\quad$ L $\quad P$ & $\mathrm{H}$ & 5 & 8.3 & 5 & 5.8 \\
\hline $\mathrm{L} \quad \mathrm{D} \quad \mathrm{H}$ & $\mathrm{H}$ & 15 & 25.0 & 10 & 11.6 \\
\hline 総ビリルビン & $\mathrm{H}$ & 4 & 6.7 & 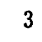 & 3.5 \\
\hline 直接ビリルビ & ンH & 2 & 3.3 & - & - \\
\hline コレステローハ & ル H & 4 & 6.7 & 5 & 5.8 \\
\hline 中性脂肪 & $\mathrm{H}$ & 15 & 25.0 & 17 & 19.7 \\
\hline 血 清 鉄 & L & 8 & 13.3 & 6 & 7.0 \\
\hline K & $\mathrm{H}$ & 6 & 10.0 & 5 & 5.8 \\
\hline $\mathrm{C} e$ & L & 6 & 10.0 & 4 & 4.7 \\
\hline $\mathrm{C} \mathrm{a}$ & $\mathrm{L}$ & - & - & 2 & 2.3 \\
\hline 無 機 燐 & $\mathrm{L}$ & 6 & 10.0 & 8 & 9.3 \\
\hline 尿素窒素 & $\mathrm{H}$ & 2 & 3.3 & 5 & 5.8 \\
\hline 尿 & $\mathrm{H}$ & 1 & 1.7 & - & - \\
\hline クレアチニン & $\mathrm{H}$ & 4 & 6.7 & 4 & 4.7 \\
\hline アルブミン & $\mathrm{L}$ & 1 & 1.7 & - & - \\
\hline 全血比重 & $\mathrm{L}$ & 6 & 10.0 & 13 & 15.1 \\
\hline
\end{tabular}

B. 医師による日常生活の指導を要する者32名

(18.1 \%)

C. 有所見者（要注意，ただし医療指導を要しない） 23名 $(13.6 \%)$

D. 所見をみとめない者 7 名 $(4.1 \%)$.

「治療を要する者」と，「医師による指導を要する者」 を合せた145名のう方，健康診断当時「医師にかかってい る」と答えた者 130名，90\%が受診していた. 15名（10 \%) は受診していない.（表21）

表21 健康診断判定区分と受診状況

(守口)

\begin{tabular}{|c|c|c|c|c|c|c|}
\hline \multirow[b]{2}{*}{ 総 } & \multirow{2}{*}{\multicolumn{2}{|c|}{ 数 }} & \multicolumn{2}{|c|}{ 医師にかかっている } & \multicolumn{2}{|c|}{ 医師にかかっていない } \\
\hline & & & 143 & $81 \%$ & 32 & 18.3 \\
\hline & 男 & & 55 & 82.1 & 12 & 17.9 \\
\hline & 女 & & 88 & 81.5 & 20 & 18.5 \\
\hline 要 & 治 & 療 & 106 & 92.9 & 8 & 7.1 \\
\hline 要 & 指 & 導 & 24 & 78.1 & 7 & 21.9 \\
\hline 要 & 注 & 意 & 12 & 52.2 & 11 & 47.8 \\
\hline 所見 & 見 な & L & 1 & 14.3 & 6 & 85.7 \\
\hline
\end{tabular}

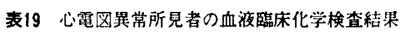

(守口)

\begin{tabular}{|c|c|c|c|c|c|c|c|c|c|c|c|c|c|c|c|c|c|}
\hline & & & 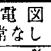 & & 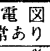 & 心荡硬塞 & 不整脈 & 朋フロック & $\begin{array}{l}V_{5-6} \\
\text { ST 低下 }\end{array}$ & $\begin{array}{l}\mathrm{V}_{1} \text {-3 } \\
\mathrm{ST} \text { 上昇 } \\
\end{array}$ & $\begin{array}{l}\mathrm{V} 5-6 \\
\mathrm{~T} \text { 逆転 }\end{array}$ & 心肥大 & 徐 脈 & 類 脈 & 左厉肥大 & 右房肥大 & 低㫣位差 \\
\hline 調 查 & 数 & $\begin{array}{c}y_{4} \\
78\end{array}$ & 100.0 & & 100.0 & $3 \%$ & 8 名 & $11^{8}$ & 30 名 & $1^{\text {名 }}$ & 18 & $18^{\text {名 }}$ & $4^{8}$ & 18 & $4^{\text {名 }}$ & 18 & 68 \\
\hline $\mathrm{G} O \mathrm{O}$ & $\mathrm{H}$ & - & - & 2 & 2.9 & - & 1 & - & 1 & - & - & - & - & - & - & - & - \\
\hline G P T & $\mathrm{H}$ & - & - & 3 & 4.4 & - & 1 & - & 2 & - & - & - & - & - & - & - & - \\
\hline A L P & H & 4 & 5.1 & 10 & 14.7 & - & - & 4 & 2 & - & - & 3 & - & 1 & - & - & - \\
\hline L D H & $\mathrm{H}$ & 15 & 19.2 & 13 & 19.1 & 1 & 1 & 3 & 4 & - & - & 1 & 2 & - & 1 & - & - \\
\hline 総ビリルビン & $\mathrm{H}$ & 4 & 5.1 & 3 & 4.4 & - & - & 1 & 2 & - & - & - & - & - & - & - & - \\
\hline 直接ビリルビン & ン $\mathrm{H}$ & - & $\ldots-$ & 2 & 2.9 & - & - & 1 & - & - & - & - & 1 & - & - & - & - \\
\hline コレステロール & $2 \mathrm{H}$ & 1 & 1.3 & 10 & 14.7 & - & - & - & 4 & - & - & 3 & - & - & - & - & 3 \\
\hline 中性脂肪 & $\mathrm{H}$ & 11 & 14.1 & 26 & 38.2 & 1 & 2 & 4 & 9 & 1 & - & 8 & - & - & - & - & 1 \\
\hline 血清鉄 & L & $?$ & 9.0 & 11 & 16.2 & 1 & - & 1 & 3 & - & - & 4 & - & - & - & 1 & 1 \\
\hline $\mathrm{Na}$ & $\mathrm{L}$ & - & - & 1 & 1.5 & - & - & - & - & - & - & - & - & - & - & - & 1 \\
\hline $\mathrm{K}$ & $\mathrm{H}$ & 6 & 7.7 & 11 & 16.2 & 1 & - & 1 & 4 & - & - & 3 & 1 & - & 1 & - & - \\
\hline $\mathrm{c} \ell$ & $\mathrm{L}$ & 2 & 2.6 & 3 & 4.4 & 1 & - & 1 & 1. & - & - & - & - & - & - & - & - \\
\hline $\mathrm{C} \mathrm{a}_{\mathrm{a}}$ & $\mathrm{H}$ & 3 & 3.9 & - & - & - & - & - & - & - & - & - & - & - & - & - & - \\
\hline 無 機 燐 & $\mathrm{H}$ & 2 & 2.6 & 10 & 14.7 & - & 2 & 1 & 2 & - & 1 & 3 & - & - & 1 & - & - \\
\hline 尿素窒絭 & $\mathrm{H}$ & 3 & 3.9 & 4 & 5.9 & - & - & - & 1 & - & - & 1 & 1 & - & - & - & 1 \\
\hline 酸 & $\mathrm{H}$ & - & - & 2 & 2.9 & - & - & - & 1 & - & - & 1 & - & - & - & - & - \\
\hline クレアチニン & $\mathrm{H}$ & 4 & 5.1 & 4 & 5.9 & - & 1 & - & 1 & - & - & 2 & - & - & - & - & - \\
\hline アルプミン & L & - & - & 1 & 1.5 & - & - & - & - & - & - & - & 1 & - & - & - & - \\
\hline 全血比重 & L & 10 & 12.8 & 9 & 13.2 & 1 & - & 2 & 2 & - & - & 2 & 1 & - & 1 & - & - \\
\hline
\end{tabular}

（H：基準值より高値者、 $\mathrm{L}$ ：基準值より低值者）

表20 老人健康診断·事後措置判定区分

(守口)

\begin{tabular}{|c|c|c|c|c|c|c|c|c|c|c|c|c|c|c|}
\hline & 総 & 数 & & 男 & & 女 & & 抹満 & 70 才一 & -75才末満 & 75才。 & -80才未満 & 80 & 拟上 \\
\hline 受検者数 & 175 & 100.0 & 67 & 100.0 & $\begin{array}{r}8 \\
108\end{array}$ & 100.0 & 60 & 100.0 & $\begin{array}{l}\text { 名 } \\
46\end{array}$ & 100.0 & 43 & $100 . \%$ & 26 & 100.0 \\
\hline 要 治 療 & 114 & 65.1 & 47 & 70.1 & 67 & 62.0 & 36 & 60.0 & 29 & 63.0 & 28 & 65.0 & 21 & 80.8 \\
\hline 要 指 導 & 31 & 17.7 & 9 & 13.4 & 22 & 20.4 & 11 & 18.3 & 7 & 15.2 & 10 & 23.3 & 3 & 11.5 \\
\hline 要 注 意 & 23 & 13.1 & 6 & 9.0 & 17 & 15.7 & 10 & 16.7 & 10 & 21.7 & 3 & 7.0 & - & - \\
\hline 所見なし & 7 & 4.0 & 5 & 7.5 & 2 & 1.9 & 3 & 5.0 & - & - & 2 & 4.7 & 2 & 7.7 \\
\hline
\end{tabular}




\section{まとめ}

守口市に在住する65才以上の老年者についてアンケー 卜調査と健康診断を行った.

\section{I アンケート調查の結果}

1. 世帯類型：男の87\%が有配偶，女の67\%が無配偶 であり，1 人暮し $16 \% ， そ の 90 \%$ 女である.

2. A D L : 要全介助 $3 \%$, 要部分介助 $2 \%$, 全国大 都市並み。

3. 病気がある $44 \%$ ，気にやむととがある $54 \% ，$ 愁訴 があるむの74\%.

4. 日常生活：女は「家庭のこと」58\%，「働きごと」 11\%，「勝手なこと」21\%，男は「働きごと」25\%，「家 庭のこと」15\%，「勝手なとと」が60\%を占め，半ばは無 為, 無聊をかこつ.

5. 住まいと食生活：居室が4畳半以下のものが $21 \%$, 日当りのよい部屋がほしい, 庭がほしいなど, 都市勤労 者の劣悪な住居条件は老人にしわよせられている. 入浴 介助と内風呂をのぞむむのがある．独居老人には食事作 りの援助あるいは給食を要望するものがある.

6. 人間関係：老女と高令者には家族や近降との人間 関係がよくないるのがある.

7. 老年者の意識と望み

1）長生きしたくない10\%あり，80才以上の高令者, 病気がある，家族内に問題がある老人が訴えている.

2）老令年金の増額を望む $42 \%$ ，生活援助金，生活保 護法通用を望むもの少々あり，

3 ）家族の世話, 話相手, 手助けを求めるもの, あわ せて19\%, 独居老人, 有病老人の切実な要求である.

\section{II 健康㖣断の結果}

1 自覚症状：あり $96 \% ， 1$ 人当り病訴件数 4.1 件, 各種の愁訴が重複する.

2 有所見者: $97 \%, 1$ 人当り 2.7 件, 合併症が多い. 老人のほとんどすべてに異常所見を認める.

3 異常所見の種類之有病率: 循環器疾患の有病率 61 \%もあり，うち心電図異常 $47 \% ，$ 高血圧症 $42 \%$, 筋・関 節・骨格系疾患 $34 \%$, うち腰痛症 $20 \%$, 運動障害 $13 \%$, 白内障 $17 \%$, 難聴 $15 \%$, 神経痛 $14 \%$, 夜間頻尿 $16 \%$, 気 管支炎 $10 \%$ ，喘息 $6 \%$ ，糖尿病 $6 \%$, 貧血 $6 \%$ ，䑈血管 疾患後遺症 $5 \%$, 肝疾患 $4 \%$ なぞ.

4 循環器疾患阮て

1 ）心電図異常の内容： $V_{5-6} S T$ 低下の有所見率 $17 \%$, 心肥大 $10 \%$, 脚ブロック $6 \%$, 不整脈 $5 \%$. 男は脚ブロ ックと不整脈が高率，女はV 5-8低下が高率である.
2) 高血圧症は非高血圧症に比べて心電図異常, 特に 心肥大が有意に高率である.

3) 心電困異常を認める者は認めない者に比べて中性 脂肪高値者が高率である (有意差).

5 有所見者の措置区分と受診状況

要治療者 $65 \%$, 要指導者 $18 \%$, 要注意者 $13 \%$, 前 2 者 を合せた要医療者の $90 \%$ は健診当時受診していた.

\section{秸语}

都市化，核家族化のなかで，都市老人は半ばは「する こと」がなく，無㽖をかこち，社会生活から㻋外されて いる傾向がある.なかでも「1人暮し老人」「ねたきり 老人」は「孤独化」「心身の不調」から「社会的植物人 間」への道をたどるおそれがある.

老人がもとめているるのは単に「保護」「介助」され るだけではない，老人なりにその能力に応じた自立的， 自主的な「生きざま」をもとめ，その援助と励ましを望 んでいる. これらの点に配虑して，老年者の老化にとも なう身体的，精神的状況に対応して必要な保健医療. 介 助の専門的サービス, 食, 住, 入浴, 援助などの福祉サ ービス, および経齐的保障のうらづけが必要である.

著者の調查により，都市老人の高い受診率は，老化に よる心身不調，高率な病状と異常所見から考えて必然で あることが明らかとなった，あわせて都市老人の疎外状 況と福祉施策の欠如により，そのはけ口を医療機関に求 める傾向から，高い受診率を生む可能性がないとはい兑 ないが，問題は「老人医療の内容」であり，老人たちの 要望に答えているとはいえない. 老人たちは医療にたい して多くの要求をむっている.

必要なことは「老人医療の抑制」ではなく, 健康観察 と相談, 看護, 介助, リハビリテイション指導などの医 療, 保健, 福祉を総合する保護サービスと日常的な「老 人健康管理」のとりくみである.さらに都市老人が阼入 りやすい「孤独化」と「人間疎外」を防き，老人の「社 会参加」を促がす対策によって「生きがい」が賦活され ることを望んでいる. 


\section{第 2 篇 和歌山県一漁村における老年者の健康と}

\section{生活構造並びに意識に関する調査結果}

和歌山県日高郡美浜町三尾は県の西海岸沿いの漁村で あり，西端は日の炠燈台が位置する．その人口構成は県 下の他地域に比べて高年者がいちじるしく多く，「長寿 村」とよばれている. 当地区において, 老人の生活と健 康並びに意識とその要望するものを調査した。

\section{地域事情}

三尾地区はかっての日高郡三尾村であり，1954年，和 田村, 松原村と合併して「美浜町」となった：地区の面 積 $4905 \mathrm{~km}^{2}$, 山林 13 町 7 反, 水田 40 町 7 反, 畑 13 町 9 反, 宅地 26,639 坪, 山林の $3 / 2$ は笹山である. 当地区の特殊 性柱民がカナダはじめ海外へ，出稼ぎするものが多い ことである. すでに1880年代に工野某の単身カナダ渡航 以来，渡航者がつづき，1913年～1927年の間に 1, 000 名 に及んだという．1887年にはカナダに「三尾村人会」が 創設され，現在は会員数約 4,500 名，三尾地区人口の 5 倍に及ぶといわれ，主として漁業に従事し，他の分野で も活躍している. 三尾地区の住民には彼の地にいる縁者 との交流を続けているものが多い，海外渡航移民者に は, 老後, 気候温暖な (年平均 $1^{\circ} \mathrm{C} \sim 17^{\circ} \mathrm{C}$ ) 郷里に帰 り，余生をおくる風習がある。このような事情から当地 区は「アメリカ村」と通称されている。1935年には人口 1,482人，415戸あった。 これをピークとして，次第に 人口は減少している. ある年の調查では戸数 400 戸, 人 口 1,200 人であったが，戸籍人口 3,300 人あり，約 2,000 人が海外纪出ており，二重国籍を持っている者が多い. この地には老人, 子供, 女性が残っている.

近年, 近隣地域への出稼ぎ転出者が増えており，空家 が約30戸あるといわれる。産業人口構造は第一次産業人 口が隇少し, 第 2 次産業人口, 第 3 次産業人口が増え, これらが優位を占め, かっての半農半漁の性格を薄めて いる.

\section{I．人口調查並びに死亡調查}

当地区は現在，行政区ではなく，人口構成並に人口異 動に関する統計資料は官庁においても整っていない，著 者は美浜町役所において三尾地区の住氏票並びに死亡票 を総点検して，1979年12月 1 日現在の性別年令別人口構 成と 1973年以降の老年者の性別・年令別・死亡と死因別 死亡数を調查した.

\section{1 人口構成}

1979年12月 1 日現在, 総世帯数388戸, 総人口878名, 男417名, 女461名, 性別, 年令別構成は図のごとく特異

三尾地区・人口構成

一性別・年令別一 (1979年12月)

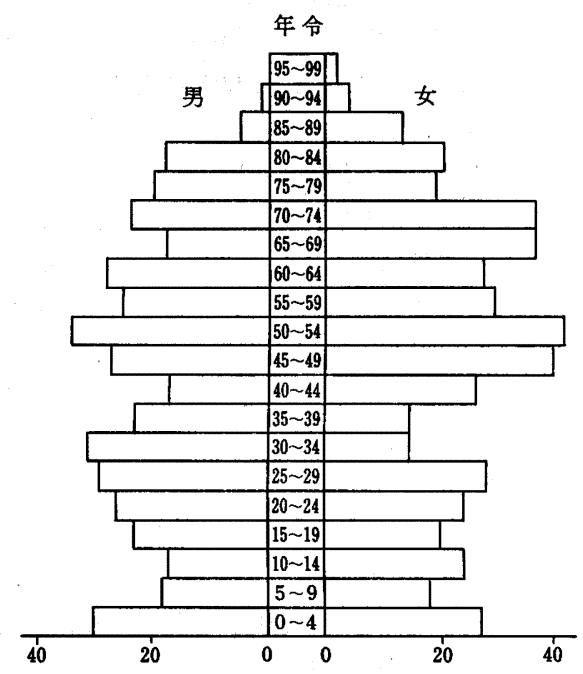

である. 全人口構成に比べて，年少者人口の割合が小さ く，高年者人口の割合が著しく大きい，すなわち，0才 ～14才(年少人口） 134名，総人口の $15.3 \%$ に対して， 65 才以上 219 名, 総人口の $24.9 \%$ ある. なお 15 才 64 才 （生産年令人口）525名, 総人口の $59.8 \%$ であり, 老年人 口指数 41.7 ，老年化指数 163.4 である. 1979年の全国人 口における年少人口百分比 23.8 , 生産年令人口百分比 67.3 ，老年人口百分比 8.9 であり，老年人口指数 13.2 老 年化指数 37.3 . 和歌山県人口のそれらはそれぞれ年少人 口百分比 22.4 , 生産年令人口百分比 65.8 , 老年人口百分 比11.8，老年人口指数 17.9 , 老年化指数 52.4 ，すなわち 全国および和歌山県人口に比べて，老年人口の割合が著 しく大きい，なお高令者率(75才以上人口/65才以上人口 $\times 100 ）$ は 47.7であり, 全国1979年 34.5 , 和歌山県人口 36.0に比べて異常に大きい. 当地区は老年人口, とくに 高令者の割合が大きいことが特色である．これが「長寿 村」とよばれている所以であろう. しかし老年化指数は 異常に大きく，「老化人口」でもあり，人口減少は急速 
に進むことが予想される。

\section{2 老年者死亡の検討}

三尾地区における人口構成の特殊性は老年人口の割合 が大きく，特に高令者が多い，その理由を検討するには 過去の人口構成と人口異動を分析しなければならない， しかし当地区は現在，行政区でなく，人口統計が整って いないまた人口移動も多く，人口分析は容易でない が，全国の死亡統計から期待值を算出し，老年者死亡の 分析を試みた。

\section{1）年令別死亡実数之死亡期待値}

当地区の性別，年令別人口構成を1979年12月 1 日現在 で調査した．仮りに，これを基準人口として，その65 才以上人口に，全国の1976年及び1977年の性別・年令別 死亡率をあてはめて，死亡期待値を算出し，当地区の 1976年及び77年の性別・年令別死亡実数とを比較した

（表 1)。その結果，高令者，とくに女の死亡実数が期 待値よりむ小さいことを認めた.

\section{2 ) 死因別死亡数と死亡期待值}

当地区の1973年以降 5 年間における65才以上の死亡数 は87名，男44名，女43名である。死因は悪性新生物 23 名, 心疾患 20 名, 脳血管疾患 16 名, 老衰 15 名, 肺炎・気 管支炎 4 名，その他の死因 9 名である.

1973年以降 5 年間の全国, 男女別・死因別死亡数の百
分比の平均を三尾地区の同年間の男女別の総死亡数に, それぞれ乗じて死因別の死亡期待值を算出し，これと死 亡実数とを比較した．その結果，「脳血管疾患」と「5 大死因」を除くその他の死因による死亡数が期待値より 小さく, 老衰, 心疾患, 悪性新生物汇因る死亡数が期待 值より大きいことを認めた。但し，脳血管疾患と悪性新 生物については危険率 $5 \%$ 以上であり，有意性を認めな い(表 2).

さて三尾地区の人口構成が前述のごとくとくに高令者 が多く，老衰と心臟病に因る死亡が多かるべきものと考 慮すると，「5大死因」以外の死因による死亡は全国水 準より少ない可能性が想定される.

ただし，前述した年令別死亡率及び死因別死亡に関す る知見は，一時的現象か，あるいは恒常的事象でありう るか，その判断は慎重でなければならない，今後に残さ れた検討課題である.

\section{III. アンケート調查結果}

当地区において，老人の健康，生活構造並びに意識に 関する知見を得る目的で，アンケート調査をおこない， ひきつづき健康診断をおこなった．実施時期は1979月 9 月〜12月である.
表 1 三尾地区老人の死亡数と死亡期待値

\begin{tabular}{|c|c|c|c|c|c|c|}
\hline & \multicolumn{2}{|r|}{ 男 } & \multicolumn{2}{|r|}{ 女 } & \multicolumn{2}{|r|}{ 計 } \\
\hline 65才〜70才未満 & 1 & $(1.0)$ & 1 & $(1.1)$ & 2 & $(2.1)$ \\
\hline 70才〜75才未満 & 3 & $(2.3)$ & 0 & (1.3) & 3 & $(3.6)$ \\
\hline 75才～80才未満 & 3 & (3.2) & 1 & $(3.4)$ & 4 & $(6.6)$ \\
\hline 80才〜85才未満 & 3 & $(4.6)$ & 1 & $(8.9)$ & 4 & (13.5) \\
\hline 85 才以上 & 3 & $(3.4)$ & 5 & $(6.5)$ & 8 & $(9.9)$ \\
\hline 計 & & (14.5) & 8 & $(20.5)$ & & $(35.0)$ \\
\hline
\end{tabular}

〔注：（）内は1976年、1977年の全国・性別・年令別・死亡率の 平均を当地人口に当てはめて算出した死亡期待值了
表 2 三尾地区、老人の死因別死亡数と死亡期待値（1973 77年）

\begin{tabular}{|c|c|c|c|c|}
\hline & 男 & 女 & 計 & 備 考 \\
\hline 脳血管疾患 & $8(11.1)$ & $8(11.7)$ & $16(22.8)$ & $\chi^{2}=2.19$ \\
\hline 悪 性 新 生物 & $13 \quad(8.9)$ & $10 \quad(7.5)$ & $23(16.4)$ & $\chi^{2}=2.91$ \\
\hline 心 疾 患 & $7 \quad(5.2)$ & $13 \quad(6.7)$ & $20(11.9)$ & $\chi^{2}=11.03$ \\
\hline 老 & $6 \quad(1.4)$ & $9 \quad(2.9)$ & $15 \quad(4.3)$ & $\chi^{2}=28.26$ \\
\hline 肺炎 · 気管支炎 & $3 \quad(2.3)$ & $1 \quad(2.2)$ & $4 \quad(4.5)$ & \\
\hline その他の死因 & $7(15.0)$ & $2(12.0)$ & $9(27.0)$ & $\chi:^{2}=17.40$ \\
\hline 計 & $44 \quad(44)$ & $43 \quad(43)$ & $87 \quad(87)$ & \\
\hline
\end{tabular}

〔注：( )内は1973年以降 5 年間の全国・65才以上・性別・年令別・死因別・死 亡百分比の平均を三尾地区・ 65 才以上·性別・死亡総数に乗じた各死因·死 亡期待値]
表 3 老年者調查の対象 一性別・年令別一

\begin{tabular}{|c|c|c|c|c|c|c|c|c|c|c|}
\hline \multirow[b]{2}{*}{ 調査数 } & \multirow{2}{*}{$\frac{\text { 総 }}{191}$} & \multirow{2}{*}{$\frac{\text { 数 }}{100.0}$} & \multicolumn{2}{|c|}{ 65才〜70才未满 } & \multicolumn{2}{|c|}{ 70才〜 75才未満 } & \multicolumn{2}{|c|}{ 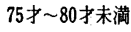 } & \multicolumn{2}{|c|}{80 才以上 } \\
\hline & & & 52 & 27.2 & 52 & 27.2 & & 18.8 & 51 & 26.7 \\
\hline 男 & 76 & 100.0 & 16 & 21.1 & 19 & 25.0 & 20 & 26.3 & 21 & 27.7 \\
\hline 女 & 115 & 100.0 & 36 & 31.3 & 33 & 28.7 & 16 & 13.9 & 30 & 26.1 \\
\hline
\end{tabular}

\begin{tabular}{|c|c|c|c|c|c|c|}
\hline & 総 & 数 & & 男 & & 女 \\
\hline 調 査 数 & & 100.0 & & $100 \%$ & $\begin{array}{r}8 \\
115\end{array}$ & $100 . \%$ \\
\hline 配偶あり & 110 & 57.6 & 66 & 86.8 & 44 & 38.3 \\
\hline 配偶なし & 81 & 42.4 & 10 & 13.2 & 71 & 61.7 \\
\hline 家族同居 & 79 & 41.4 & 31 & 40.8 & 48 & 41.7 \\
\hline 夫婦暮し & 67 & 35.1 & 38 & 50.0 & 29 & 25.2 \\
\hline 一人暮 L & 45 & 23.1 & 7 & 9.2 & 38 & 33.0 \\
\hline
\end{tabular}




\section{1 調查対象}

65才以上人口 219 名のうち, 回答したもの191名, 回答 率87.2\%。：男 76名, 女 115 名, うち 80 才以上 51 名, 最高 令者は97才，男である(表 3 )。

1）䟕偶関保及び世帯颣型：有配偶は男の87\%である のにたいして，女は38\%，大部分が無配偶である(表 4).

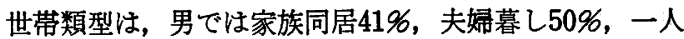
暮し $9 \%$ にたいして，女では家族同居42\%，夫婦暮し 25

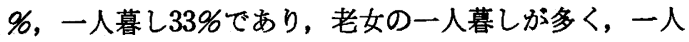
暮し老人の84\%は女で占められる. 1978年の厚生行政基 礎調査によると，60才以上の高年者のいる世帯の単独世 帯（1 人暮し）は $10.2 \%$ ，夫婦のみの世帯 $16.3 \%$ ，その 他の世帯（家族同居）73.6\%である. この全国調査成績 に比べて，三尾では 1 人暮しと夫婦暮しが多く，家族同 居が少ない，女の 1 人暮し老人が多く，加令之共に独居 率が上昇する．「孤老化」は主に老女における現象であ るが,三尾ではとくに顕著である.

2）前職：男について前職を調査すると，76名中漁業 31 名 (40.8\%), 農業 8 名 (10.5\%) 大工 4 名 $(5.3 \%)$, 公務員 9 名 (11.8\%), 会社員, 船員, 僧侶, 商業など 各 1〜2 名である. 漁業の占める割合が圧倒的に大き い. またカナダ方面（一部フメリカ）に渡航，出稳ぎ体 験者であって，老後，帰郷したもの热33名，男子の 43.4 \%を占める. 渡航先での職業はほとんどが漁業（26名）
であり, 他は大工 ( 3 名), 庭師, 左官, 般員, 日本人 学校教師などである。いずれも相当期間，海外移住し， 老後に帰郷したものである．女の前職は，極く一部に家 業手伝い，保健婦，へルパー業あるほがはほとんどが主 婦である．夫の職業は漁業（34名）がもっとも多く, 農 業 ( 5 名) 会社員, 教員, 建設業, 商業, その他各種で ある. また夫が海外渡航経験者であるるのが 38 名 (30.9 \%) むあり，多くは，夫に随伴して渡航し，帰郷したも のである。

\section{3) 日常生活能力 AD L}

調査対象者の自己判断によるADLは，「自分ではほ とんどできないので人に助けてもらう必要がある」（要 全介助者) 14 名， $7 \%$ ，(男 2 名，女12名)，「自分でで きることもあるが人に助けてもらう必要がある」（要部 分介助) 12 名, $6 \%$ (男 3 名，女 9 名). 「不自由なところ ああるが助けてもらわない」（部分独立）30名，15.7\% (男16名，女14名)，「不自由なところがなく自分で出来 る」（全独立）135名，70.7\%（男 55名，女80名）であ る. すなわち全介助，部分介助合せて介助を要するもの 19名，13\%である(表 5 )。

ねたきり老人は 6 名， 3.1 名(男 1 名女 5 名）である.

なお面接調査の結果，妻または家族の介助をえている あのであって「介助を要しない」と回答しているものが あり゙とくに高令者にその傾向があった.

表 5 老人の日常生活能力 $\mathrm{ADL}$

(三尾)

\begin{tabular}{|c|c|c|c|c|c|c|c|c|c|c|c|c|c|}
\hline & \multicolumn{2}{|c|}{ 辁 数 } & \multicolumn{2}{|r|}{ 男 } & \multicolumn{2}{|c|}{ 女 } & \multicolumn{2}{|c|}{ 65才〜70才未洞 } & 70才 75才末满 & \multicolumn{2}{|c|}{ 75才 80才末消 } & \multicolumn{2}{|c|}{80 才以上 } \\
\hline 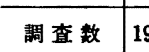 & 191 & 100.0 & 76 & $100.0^{x}$ & 115 & $100.0^{\circ}$ & $\begin{array}{ll}52 & 10\end{array}$ & & $\begin{array}{ll}52 & 100.0\end{array}$ & 36 & $100 . \%$ & & $100.0^{x}$ \\
\hline 要全介助 1 & 14 & 7.3 & 2 & 2.6 & 12 & 10.4 & 1 & & $7: 7$ & 3 & 8.3 & 6 & 11.8 \\
\hline 要部分介助 1 & 12 & 6.3 & 3 & 4.0 & 9 & 7.8 & 2 & .8 & 7.7 & 2 & 5.6 & 4 & 7.8 \\
\hline 部分独立 & 30 & 15.7 & 16 & 21.0 & 14 & 12.2 & 5 & .6 & 15.4 & 7 & 19.4 & 10 & 19.6 \\
\hline 全 独 立 13 & 135 & 70.7 & 55 & 72.4 & 80 & 69.6 & 44 & & 69.2 & 24 & 66.7 & 31 & 60.8 \\
\hline \multicolumn{10}{|c|}{ 表 6 ・老人の日常生活 } & \multicolumn{4}{|r|}{ (三尾) } \\
\hline & \multirow{2}{*}{\multicolumn{3}{|c|}{ 男 }} & \multirow{2}{*}{\multicolumn{2}{|c|}{ 女 }} & \multicolumn{4}{|c|}{ 65才〜75才未溍 } & \multicolumn{4}{|c|}{75 才以上 } \\
\hline & & & & & & \multicolumn{2}{|r|}{ 男 } & \multicolumn{2}{|r|}{ 女 } & \multicolumn{2}{|c|}{ 男 } & \multicolumn{2}{|r|}{ 女 } \\
\hline 调 查 数 & 76 & $6 \quad 100$ & $0 . \%$ & 115 & $100.0^{x}$ & 35 & $100 . .^{*}$ & 69 & $100.0^{*}$ & & $100 . .^{*}$ & 46 & $100.0^{*}$ \\
\hline 田畑の仕事 & 27 & 35 & 35.5 & 31 & 27.0 & 16 & 45.7 & 24 & 34.8 & 11 & 26.8 & 7 & 15.2 \\
\hline 山林の仕事 & & 4 & 5.3 & 1 & 0.9 & 2 & 5.7 & 1 & 1.4 & 2 & 4.9 & - & - \\
\hline 海 辺の仕事 & & 6 & 7.9 & 5 & 4.4 & 4 & 11.4 & 4 & 5.8 & 2 & 4.9 & 1 & 2.1 \\
\hline 家業，手伝い & 13 & 17 & 7.1 & 14 & 12.1 & 6 & 17.1 & 7 & 10.1 & 7 & 17.0 & 7 & 15.2 \\
\hline 家 & & 11 & 1.8 & 70 & 60.9 & 3 & 8.6 & 48 & 70.0 & 6 & 14.6 & 22 & 47.8 \\
\hline 子守り孫守り & & 2 & 2.6 & 7 & 6.1 & 1 & 2.9 & 5 & 7.2 & 1 & 2.4 & 2 & 4.3 \\
\hline つれあいの世話 & - & - & - & 8 & 7.0 & - & - & 5 & 7.2 & - & - & 3 & 6.5 \\
\hline 㠹の & & 1 & 1.3 & 11 & 9.6 & - & - & 6 & 8.7 & 1 & 2.4 & 4 & 8.6 \\
\hline 庭の手入れ & 16 & 21 & 1.0 & 16 & 13.9 & 7 & 20.0 & 8 & 11.6 & 9 & 22.0 & 8 & 17.4 \\
\hline 好 き な 事 & 23 & 30 & 30.3 & 22 & 19.1 & 15 & 4.3 & 10 & 14.5 & 8 & 19.5 & 12 & 26.1 \\
\hline 何もしてない & 18 & 23 & 3.7 & 17 & 14.8 & 2 & 5.7 & 5 & 7.2 & 16 & 39.0 & 12 & 26.1 \\
\hline
\end{tabular}




\section{2 生活構造}

\section{1) 日常生活}

「日頃，主に何をしていますか」という質問にたいし $\tau$, 男の場合は, 田畑の仕事36\%，家業手伝い17\%，家 事11\%であり，好きな事をする30\%，庭の手入れ $21 \%$, 何もしていない24\%である, (表 6, 重複回答あり). 女の場合は, 家事61\%が圧倒的に多く, 田畑の仕事27\%, 家業手伝い12\%あり，好なことをする19\%，庭の手入れ 14\%，何もしていない15\%である.「働きごと」「家庭 の仕事」「勝手なこと」に大分類すると, 男は「働きご と」と「勝手なこと」がともに44\%，「家庭の仕事」10 \%. 女は「家庭の仕事」が過半を占め，「働きごと」が 32\%であり「睠手なとと」は17\%にすざない，男女とも に，75才以上になると，「働きごと」が減りり，「勝手 なこと」「何もしない」が増える.

\section{2）食亭について}

食事の用意 : 男は83\%が「家族が作る」，女は「自分が つくる」69\%，「家族が作る」24\%，男女にちがいがあ る. 家族が持ってくる 5 名 (2.6\%). 「食事の用意に不 自由している」と答えたものが 3 名あった.

主食 : 米飯のみ $45 \%$, 米とパン併食 $47 \%$, 朝食は大部 分がパン食である.

副食物の種類：「毎日食べる副食物」は，野菜（男86 〜女90\%)。魚(男58\%), 牛乳(男45～女 $48 \%)$, 卵 (40 〜41\%). 「稀にしかたべない食品」はインスタント食 品(66〜76\%)，八厶 $(8 \sim 52 \%)$, カマボコ (53\%)牛 釈（42\%）などである. 海草は「ときどき食べる」が多 い. 男女差は著明でない(表 7).

㖺好品：好きなものは「甘いもの」が比較的多い(50 \%).「酢っぱいもの」(11\%)，「甘辛」(10\%) は好
まない，酒をのむ13\%，煙草をすう23\%であるが，笑㖶 量は少なく，1日量最高が紙巻煙草 7 本である.

\section{3 ）住まいと入浴}

居室：4.5畳以下が 43\%を占める(表 8 ). 日当りは一 般によく, 北側に天空を作り, 外地の慣習を残している.

入浴：毎日入浴する $64 \%$ ，隔日または週 2 回〜 3 回22 \%, 不自由するものは少ない。

\section{4) 年金}

175名(91.6\%) 肪何らかの年金を受けている. 老令年 金89名（45.6\%）がもっとも多く，国民年金49名（25.7 \%)がこれに次ぐ，遺族年金 4 名(2.1\%)，恩給10名(5.2 $\%)$ ，軍人恩給 3 名 (1.6\%). 別にカナダ年金受給者 15 名, $7.9 \%$ (男 8 名, 女 7 名, カナダ在住 20 年以上のもの に給付され，カナダペンションという，月額200ドル).

\section{5 ) 家族との関係}

80\%はうまくいっているという，家族との関係がよく ないもの3名 (1.6\%) あった.

\section{3 愁訴と医㞠に関する要望}

\section{1) 愁挀}

愁訴に関する回答者 182 名のうち, 何らかの愁訴ある もの121名，66.5\%（表 9). 男60.6\%，女70.3\%，女が やや高率であるが, 有意差でない. 75才未満 $60.4 \%, 75$ 才以上74\%，高令者は愁訴率が高い.

\section{愁訴の種類}

血圧が高い $(17 \%)$, 腰痛 $(17 \%)$, 関節痛 $(12 \%)$ が 高率な訴えであり，心臓が悪い（7％)，胃が悪い，便 泌（ともに 4\%) などの訴えがつゔく．性別には著差を みとめないが, 年令別には75才以上は75才未満に比べ て，血圧が高いと腰痛が比較的高率である.

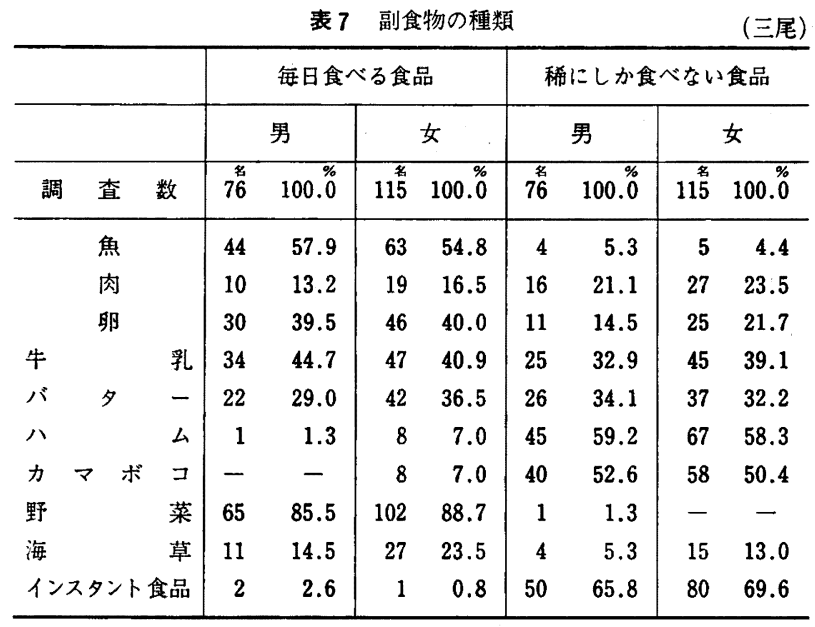

\begin{tabular}{|c|c|c|}
\hline 調 査 数 & $191^{8}$ & $100 . \%$ \\
\hline 3 畳以上 & 13 & 6.8 \\
\hline 4.5 畳 & 70 & 36.7 \\
\hline 畳 & 78 & 40.8 \\
\hline 畳 & 22 & 11.5 \\
\hline
\end{tabular}




\section{2）受肜状況と医療に関する要望事項}

当地㤝在，無医地区であり，3〜 $4 \mathrm{~km}$ 離れた医院に 受診する.「医者们かっている」40\%(表10). 性別に は著差をみとめないが，75才以上高令者の受診率はやや 高くなる. 受診率の前述した愁訴率にたいする比は 0.6 であり，愁訴をもつるのの $40 \%$ 受診していない.

医療に関する要望事項 : 回答者の半ば近く 80 名 $(42$ \%)が「近くに医者がほしい」といい，無医地区解消を望 んでいる，健康相談をうけたい $(60$ 名，31\%），巡回診 療を望むもの (30名，22\%) がかなりある. 歯科診療 (11名，6\%), 医者稀てもらいたい(5名，3\%), 保 健婦に来てほしい(6名，3\%). ヘルパーに来てほしい
(7 名，4\%)，マッサージをしてほしい（13名，7\%) ハリをしてほしい (5名，3\%), あう眼鏡がほしい(14 名, 7\%), 雬医者にかかりたい (11名，6\%), 温泉に 行きたい $(10$ 名， $5 \%)$ など, 少数ながらも切実な要求で あり，また看護人の派遣をるとめるもの各々 3 名あり， 地域における老人対策としてみのがせない(表11).

\section{4 老人の意輙と望み（贵12）}

\section{1) 健康について}

「病気が治ってほしい」50名(26\%)「もっと達者にな りたい」46名(24\%)あり，健康は老人の大きい関心事て ある.ひいては，医療に関連するさまざまな要望がある ことは前述の如くである。

表 9 アンケート調査による老人の愁訴

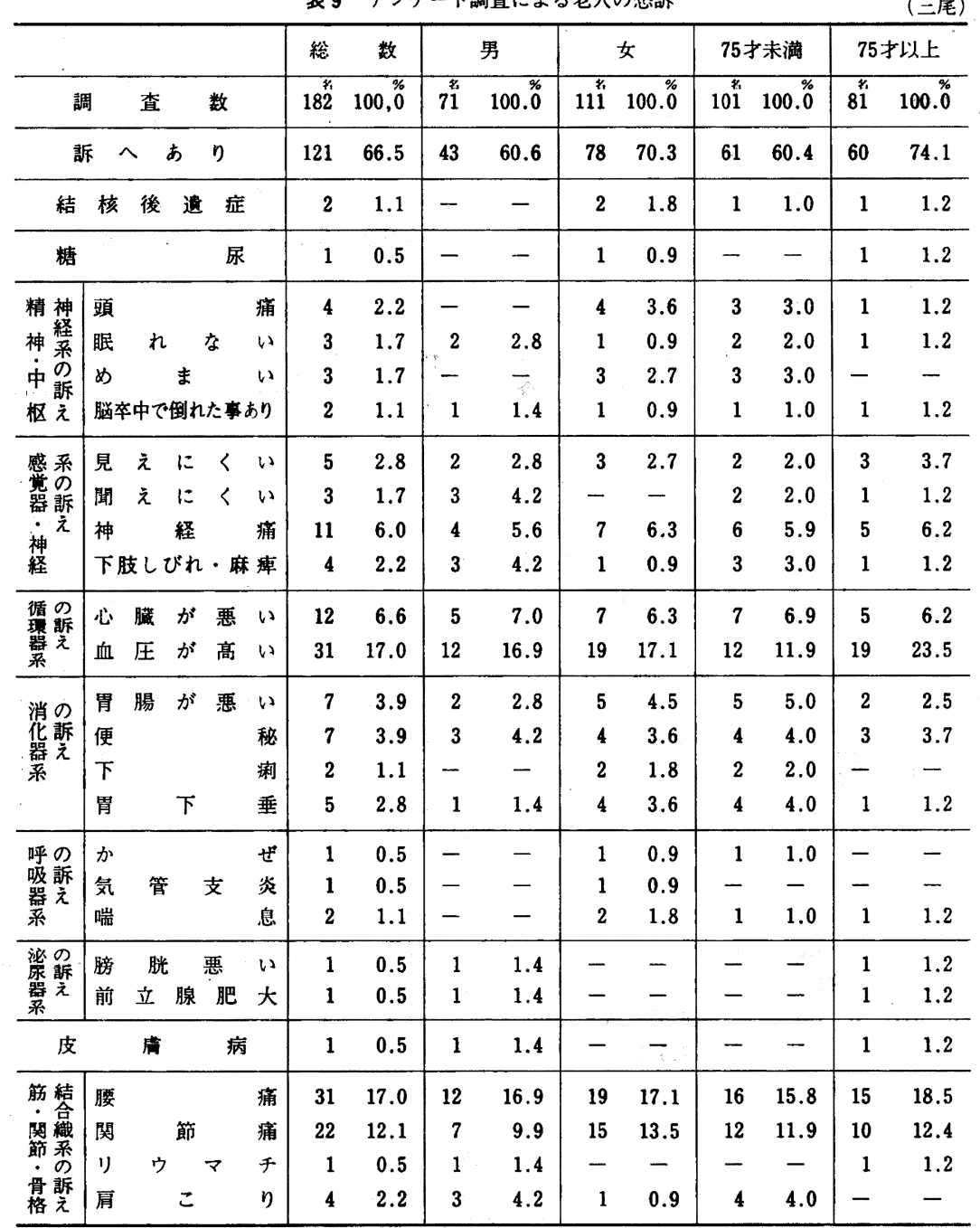


表10 老人の受療状況

(三尾)

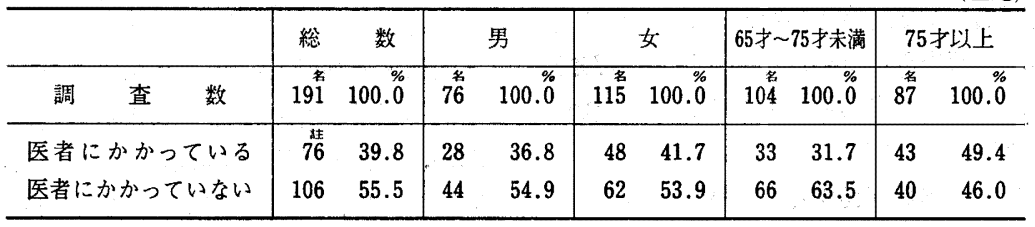

(註：合計が調查数より不足は無回答による)

表11老人の医療・介助に対する要望

\begin{tabular}{|c|c|c|c|c|c|c|c|c|c|c|}
\hline \multirow[b]{2}{*}{ 調 } & \multirow{2}{*}{$\frac{\text { 総 }}{191}$} & \multirow{2}{*}{$\frac{\text { 数 }}{100.0}$} & \multicolumn{2}{|c|}{ 男 } & \multicolumn{2}{|c|}{ 女 } & \multicolumn{2}{|c|}{ 65才〜75才未満 } & \multicolumn{2}{|c|}{ 75才以上 } \\
\hline & & & 76 & $100 . \%$ & 115 & 100.0 & 104 & 100.0 & 87 & 100.0 \\
\hline 近くに医者がほしい & 80 & 41.9 & 30 & 39.5 & 50 & 43.5 & 42 & 40.4 & 38 & 43.7 \\
\hline 健康相談うけたい & 60 & 31.4 & 22 & 8.5 & 38 & 33.0 & 31 & 29.8 & 29 & 33.3 \\
\hline 巡回診療してほしい & 30 & 21.7 & 8 & 10.5 & 22 & 19.1 & 18 & 17.3 & 12 & 13.8 \\
\hline 畨医者にかかりたい & 11 & 5.8 & 5 & 6.6 & 6 & 5.2 & 6 & 5.8 & 5 & 5.7 \\
\hline 医師に見てもらいたい & 5 & 2.6 & 2 & 2.6 & 3 & 2.6 & 0 & - & 5 & 5.7 \\
\hline あう眼鏡ほしい & 14 & 7.3 & 7 & 9.2 & 7 & 6.1 & 7 & 6.7 & 7 & 8.1 \\
\hline マッサージしてほしい & 13 & 6.8 & 3 & 3.9 & 10 & 8.7 & 9 & 8.8 & 4 & 4.6 \\
\hline ハリしてほしい & 5 & 2.6 & 2 & 2.6 & 3 & 2.6 & 4 & 3.8 & 1 & 1.1 \\
\hline 温泉へ行きたい & 10 & 5.2 & 4 & 5.3 & 6 & 5.2 & 7 & 6.7 & 3 & 3.4 \\
\hline 保健婦に来てほしい & 6 & 3.1 & 1 & 1.3 & 5 & 4.3 & 3 & 2.9 & 3 & 3.4 \\
\hline ヘルパー来てほしい & 7 & 3.7 & 0 & - & 7 & 6.1 & 3 & 2.9 & 4 & 4.6 \\
\hline 看護人ほしい & 3 & 1.6 & 2 & 2.6 & 1 & 0.9 & 1 & 1.0 & 2 & 2.3 \\
\hline 介添人ほしい & 3 & 1.6 & 2 & 2.6 & 1 & 0.9 & 2 & 1.9 & 1 & 1.2 \\
\hline 入浴の世話してほしい & 1 & 0.5 & 1 & 1.3 & - & - & 1 & 1.0 & 1 & 1.2 \\
\hline 病院に入りたい & 1 & 0.5 & 1 & 1.3 & - & - & 1 & 1.0 & - & - \\
\hline 老人ホームに入りたい & 1 & 0.5 & - & - & 1 & $0 . .9$ & 1 & 1.0 & - & - \\
\hline
\end{tabular}

表12 老人の意識と望み

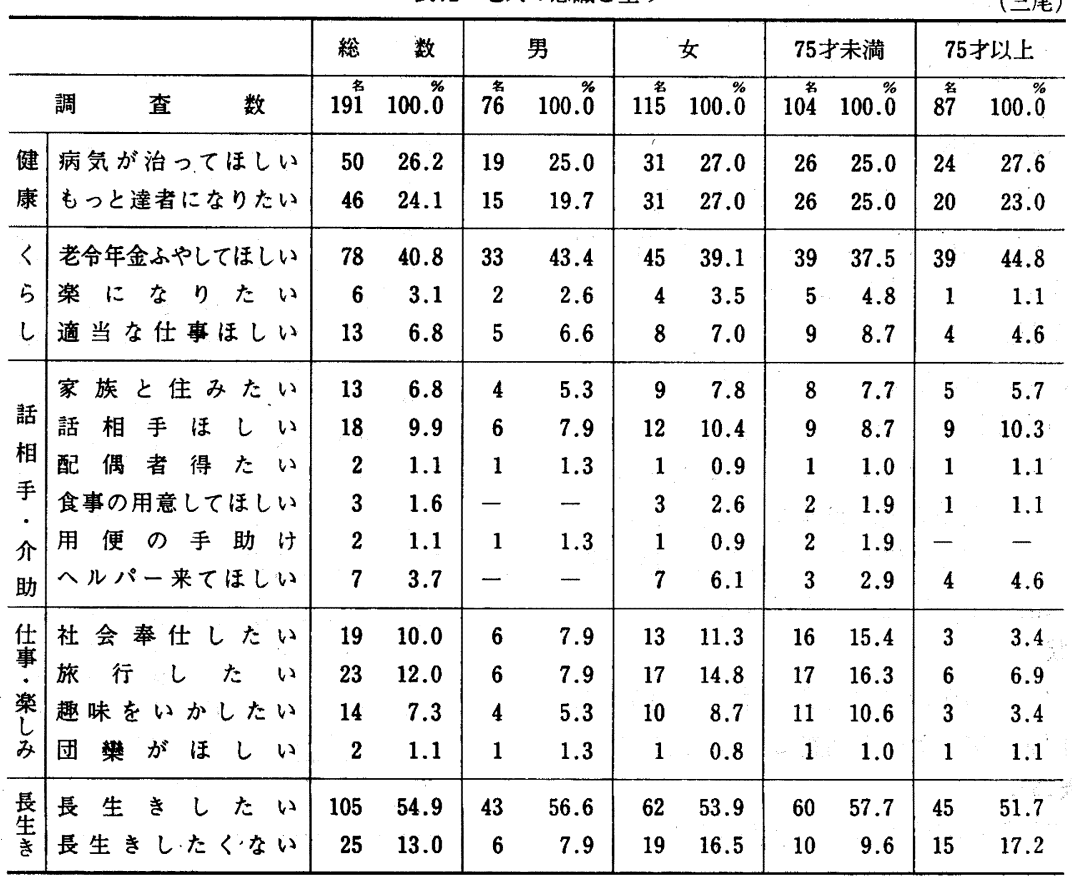




\section{2) くらしについて}

全体の41\%（74名）が「老令年金をふやしてほしい」 と要望している.「適当な仕事がほしい」13名 (17\%) 「くらしが楽になりたい」6名あることもみのがせない．

\section{3）話相手と介助について}

「話相手がほしい」18名 (10\%)，「家族と住みたい」 13名（7\%)，「配偶を要望する」2名などは，「孤老」

「淋しさ」の解消を望むむのであろう.

「食事の用意をしてほしい」3名，「用便の手助けがほ しい」2名，「へルパーに来てほしい」7名などは，少 数ながらも老人の日常のくらしの介助について切実な要 望であろう。

\section{4）仕事や楽しみについて}

他方，老人が「する仕事」がなく無聊をかこつている あのがあり，ひいては，「あう仕事をしたい」「社会奉 仕をしたい」「趣味をいかした暮しをしたい」「旅行を したい」など，老人の「生甲斐」とリクリエションにつ ながる要望である．これらの仕事や楽しみにたいする要 求は75才未満の老人につよく, 75才以上では少なくなっ ている.女は旅行や温泉などに対す関心がつよい。

\section{5) 長生きについて}

長寿は万人共通のねがいであり，55\%が表明してい る. しかし「長生きしたくない」が25名，13\%ある。 そ れは 80 才以上 $(10$ 名), 1 人暮し $(6$ 名), 病身 (12名) や家族と不和のむの（4名）などにみとめられる. 老人 の「長生き」にたいする希望を奪っている障碍をつきと め, 取り除くことこそ，「生き甲斐」をとりもどすため に不可欠な対策であろう.

\section{III, 老人徫康跈断結果}

アンケート調查回答者の半数を健康診断の対象とする 目標で，対象者を任意抽出した。 そのうち，87名（男35 名，女52名）が健康診断に応じた。

\section{<健康診断項目 >}

予診, 主訴, 既往症, 家族歴，一般理学的検査，尿検 查, 血液検查 (全血比重, 臨床化学検查), 心電図およ び長谷川式簡易知的機能テストを実施した.なお血圧測 定，心電図は30分以上安静後，背臥位で測定し，採血は 原則として食後 2 時間以上経ておこなった．血液臨床化 学検查は大阪血清微生物研究所に依頼した。

\section{1 自觉症状}

受診者86名中，何らかの自覚症状を訴元る者 72 名， 83.7\%あり，前記，アンケート調査による愁訴率よりも 增えている(表13).

また 1 人当り病訴数 1.65 件であり，複数の訴元をるつも
のがある.

病訴の種類 : 大分類について，多い順にあげると，筋 - 関節・運動器系の訴光 30 名, $34.9 \%$, を筆頭に, 脳・ 中枢神経系の訴え 26 名, 30.2\%, 呼吸器系の訴人 19 名, $22 \%$, 心蔵・循環器系の訴え15名, $17.4 \%$, きこえにく い15名，17.4\%，見えにくい12名，13.3\%，消化器系の 訴え11名，12.8\%等が続く.

個々の訴えの種類を，頻度の大きいものから順にあげ ると，聴えにくい(15名，17.1\%)，足が不自由（13名， 15.1\%), 腰痛 (12名, 14\%)，見えにくい(12名，14.0 \%)，咳 (11名，12.8\%)，頭痛，たん，喘息，（各々 8 名, 9.3\%). 便秘，階段で苦しくなる（各々 7 名， 80 $\%)$, 血圧が高い (6名, $7.0 \%)$, 手が不自由（ 5 名, 5.8\%). 以下, 動悸うつ，のほせやすい（各ヶ 3 名）, 胃が悪い，息切れしやすい，物忘れ，言葉もつれ，夜間 頻尿（3 回以上, 各々 2 名) である.

性別比較 : 女は男に比べて筋・関節・運動器の訴えが

\begin{tabular}{|c|c|c|c|c|c|c|}
\hline 伹13 老人 & 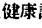 & 阯絓果 & 一自 & 觉症状一 & & (三尾) \\
\hline & 維 & 数 & & 男 & & 女 \\
\hline 妥 部 者 数 & 86 & $100.0^{x}$ & & $100.0^{*}$ & 51 & $100.0^{x}$ \\
\hline 柝 & 72 & 83.7 & 27 & 77.1 & 45 & 88.2 \\
\hline 媨・ 中权神経系の㭛え & 26 & 30.2 & 9 & 25.7 & 17 & 33.3 \\
\hline & 8 & 9.3 & 3 & 8.6 & 5 & 9.8 \\
\hline のばせ易 い & 3 & 3.5 & 1 & 2.9 & 2 & 3.9 \\
\hline 眠 & 12 & 14.0 & 2 & 5.7 & 10 & 19.6 \\
\hline 物忘れし易い & 2 & 2.3 & 2 & 5.7 & - & - \\
\hline 著茶のもつれ & 2 & 2.3 & 2 & 5.7 & - & - \\
\hline 感 堂 器 の 敦 え & & & & & & \\
\hline 兄 $え に く い$ & 12 & 14.0 & 5 & 14.3 & 7 & 13.7 \\
\hline 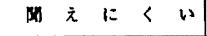 & 15 & 17.4 & 8 & 22.9 & 7 & 13.7 \\
\hline 徣理器系の挀え & 15 & 17.4 & 9 & 25.7 & 6 & 11.8 \\
\hline 血压が高 い & 6 & 7.0 & 4 & 11.4 & 2 & 3.9 \\
\hline とうきうつ & 3 & 3.5 & 2 & 5.7 & 1 & 2.0 \\
\hline 虫切れし易い & 2 & 2.3 & 1 & 2.9 & 1 & 2.0 \\
\hline 旺段で苦しくなる & 7 & 8.1 & 4 & 11.4 & 3 & 5.9 \\
\hline 呼吸器系の㭛え & 19 & 22.0 & 11 & 31.4 & 8 & 15.7 \\
\hline m & 11 & 12.8 & 6 & 17.1 & 5 & 9.8 \\
\hline$h$ & 8 & 9.3 & 6 & 17.1 & 2 & 3.9 \\
\hline 虫 & 8 & 9.3 & 3 & 8.6 & 5 & 9.8 \\
\hline 消化器采の眽 & 11 & 12.8 & 5 & 14.3 & 6 & 11.8 \\
\hline 月 か゚ 悪 & 2 & 2.3 & 2 & 5.7 & - & - \\
\hline 献 & 1 & 1.2 & - & - & 1 & 2.0 \\
\hline 秘 & 7 & 8.1 & 2 & 5.7 & 5 & 9.8 \\
\hline 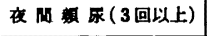 & 2 & 2.3 & 2 & 5.7 & - & - \\
\hline 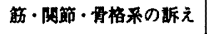 & 30 & 34.7 & 7 & 20.0 & 23 & 45.1 \\
\hline ふしふしの苹み & 1 & 1.2 & 1 & 2.9 & - . & - \\
\hline 最 & 12 & 14.0 & 3 & 8.6 & 9 & 17.6 \\
\hline 足 が 不自 由 & 13 & 15.1 & 2 & 5.7 & 11 & 21.6 \\
\hline 手 が 不 自 由 & 5 & 5.8 & 1 & 2.9 & 4 & 7.4 \\
\hline 禁针 & & $4 \pi$ & & 62 & & 80 \\
\hline 一人当り病訴数 & & 1.7 & & 1.8 & & 1.6 \\
\hline
\end{tabular}


2 倍以上である (45\%対 20\%)，とくに腰痛，足が不自 由が女に多い。女高率である.

男が女よりも高率な訴えは，呼吸器系の訴へ，心臓， 循環器の訴え（「血圧が高い」「階段が苦しくなる」） であるが有意差はない。

年令別比較 : 難聴が加令とともに高率となる.

\section{2 有所見者}

受診者86名中, 85名 (98.8\%) に何らかの異常所見を 認めた(表14).

疾病または異常所見の種類 : 大分類で, 頻度の大きい 順にあげると, 循環器系の疾患 57 名 $66.3 \%$ がっとも多 い. 神経系及び感覚器系の疾患23名, $26.7 \%$ 筋骨格系及 び結合織系の疾患18名, 20.9ðやがつづく.

疾病または異常所見の小分類では，心電図異常あり 44 名, $51.2 \%$ と高血圧 36 名, $41.9 \%$ が特に多く, 受診者の 半数前後にみとめる. 腰痛症 13 名, $15.1 \%$, 難聴12名, $14 \%$, 貧血 9 名, $10.5 \%$ 神経痛 8 名, $9.3 \%$, 白内障 5
名, 5.8\%, 夜間頻尿 (3 回以上) 4 名， $4.7 \%$, 関節障 害 3 名， $3.5 \%$ ，脳血管損傷後遺症が 1 名ある. 検尿結 果注蛋白陽性 2 名， $2.3 \% ，$ 糖陽性 5 名，5.8\%である。

長谷川式簡易知的機能テスト：老年者の精神機能につ いて長谷川式「簡易知的機能評価」をおこなった（31〜 32.5点：正常, 22〜30.5点：境界 10.5 21.5点：準痴 呆, $0 \sim 10$ 点 : 痴呆). 本テストの結果, 21.5 以下の準 痴呆（ここでは「機能低下」と記載する） 4 名, $4.7 \%$, みとめた。

性別比較：男は女に比べて，心電図異常所見，難聴， 夜間頻尿が有意に高率であり，知的機能低下は女にみと めた.

年令別比較 : 1 人当り異常所見数（合併症の数）は加 令とともに増加する. 循環器疾患, 難聴, 貧血が加令と ともに高率となる傾向があり，とくに80才以上は心電困 異常所見，高血圧症，貧血症が高率である.

\section{3 血液検烃結果}

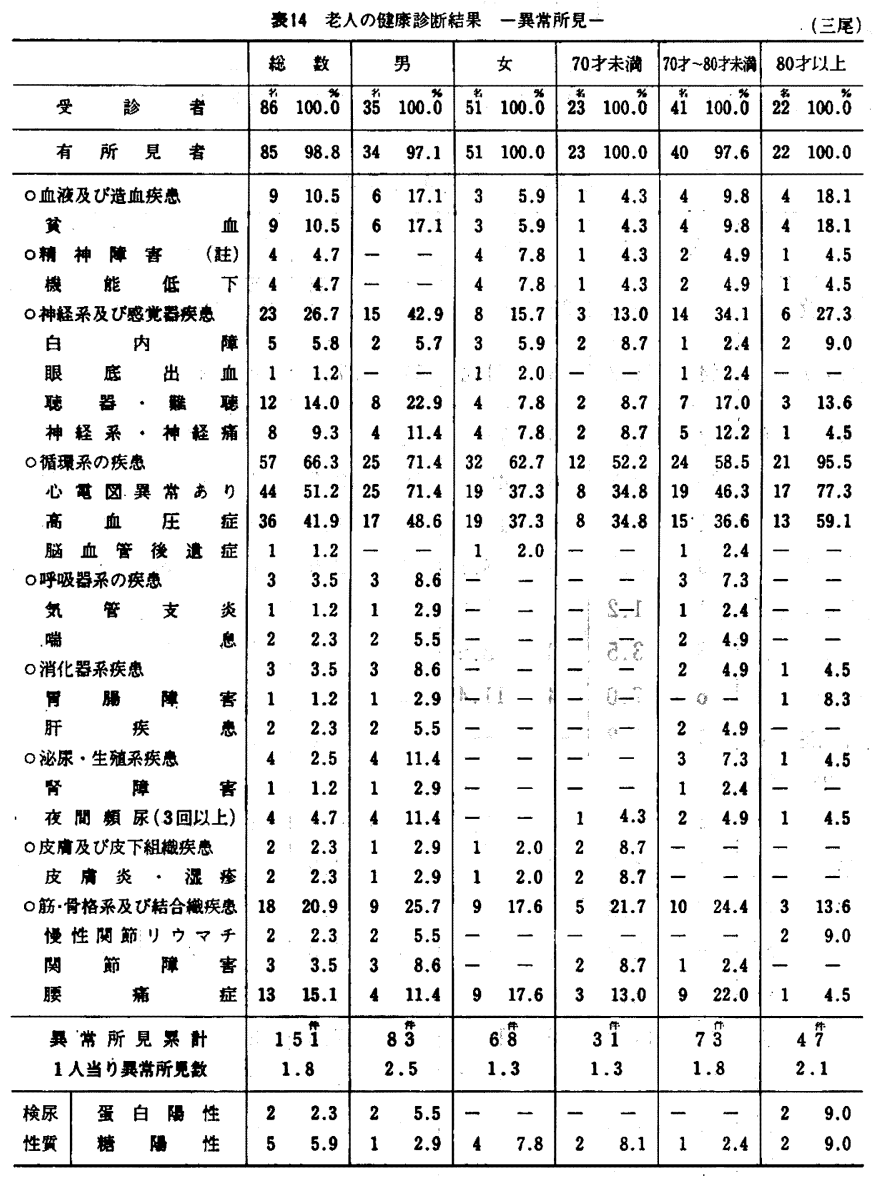

（註：長谷川テスト21.5点以下） 
表 15 血液臨床化学検査結果

(三尾)

\begin{tabular}{|c|c|c|c|c|c|c|c|c|c|c|c|}
\hline & & 総 & & \multicolumn{2}{|c|}{ 男 } & \multicolumn{2}{|r|}{ 女 } & \multicolumn{2}{|c|}{ 75才未満 } & \multicolumn{2}{|c|}{ 75才以上 } \\
\hline 検，查 & 数 & 79 & $100 . \%$ & 33 & $100 . \%$ & $\begin{array}{l}86 \\
46\end{array}$ & 100.0 & & 100.0 & $\begin{array}{l}89 \\
39\end{array}$ & 100.0 \\
\hline G $O \quad T$ & $\mathrm{H}$ & 1 & 1.3 & 1 & 3.0 & - & - & - & - & - & - \\
\hline $\begin{array}{lll}\text { G } & P & T\end{array}$ & $\mathrm{H}$ & 3 & 3.8 & 2 & 6.1 & 1 & 2.2 & 1 & 2.5 & 2 & 5.1 \\
\hline A $\quad$ L $P$ & $\mathrm{H}$ & 2 & 2.5 & 2 & 6.1 & - & - & - & - & 2 & 5.1 \\
\hline L $\quad \mathrm{D} \mathrm{H}$ & $\mathrm{H}$ & 15 & 19.0 & 5 & 15.2 & 10 & 21.7 & 8 & 20.0 & 7 & 18.0 \\
\hline 総ビリルビン & $\mathrm{H}$ & 2 & 2.5 & 1 & 3.0 & 1 & 2.2 & 1 & 2.5 & 1 & 2.6 \\
\hline コレステロール & $\mathrm{H}$ & 1 & 1.3 & - & - & 1 & 2.2 & - & - & 1 & 2.6 \\
\hline 中性脂肪 & $\mathrm{H}$ & 22 & 27.9 & 10 & 30.2 & 12 & 26.1 & 13 & 32.5 & 9 & 23.1 \\
\hline 血 清 鉄 & L & 7 & 8.9 & 3 & 9.1 & 4 & 8.7 & 2 & 5.0 & 5 & 12.8 \\
\hline $\mathrm{Na}$ & $\mathrm{L}$ & 3 & 3.8 & 3 & 9.1 & - & - & - & - & - & - \\
\hline $\mathrm{C} \ell$ & $\mathrm{L}$ & 2. & 2.5 & 1 & 3.0 & 1 & 2.2 & - & - & 2 & 5.1 \\
\hline $\mathrm{Ca}$ & L & 8 & 10.1 & 2 & 6.1 & 6 & 13.0 & 5 & 12.5 & 3 & 7.7 \\
\hline 無機 燐 & $\mathrm{L}$ & 8 & 10.1 & 5 & 15.2 & 3 & 6.5 & 2 & 5.0 & 6 & 15.4 \\
\hline 尿素窒素 & $\mathrm{H}$ & 7 & 8.9 & 5 & 15.2 & 2 & 4.4 & 3 & 7.5 & 4 & 10.3 \\
\hline 酸 & $\mathrm{H}$ & 1 & 1.3 & 1 & 3.0 & - & - & - & - & 1 & 2.6 \\
\hline クレアチニン & $\mathrm{H}$ & 4 & 5.1 & 4 & 12.1 & - & - & 1 & 2.5 & 3 & 7.7 \\
\hline 全血比重 & L & 9 & 11.4 & 7 & 21.2 & 2 & 4.4 & 5 & 12.5 & 4 & 10.3 \\
\hline
\end{tabular}

（註：H：基準值より高値、 $\mathrm{L}$ :基準値より低值、総蛋白、アルブミンの異常值なし）

表16 心電図異常所見

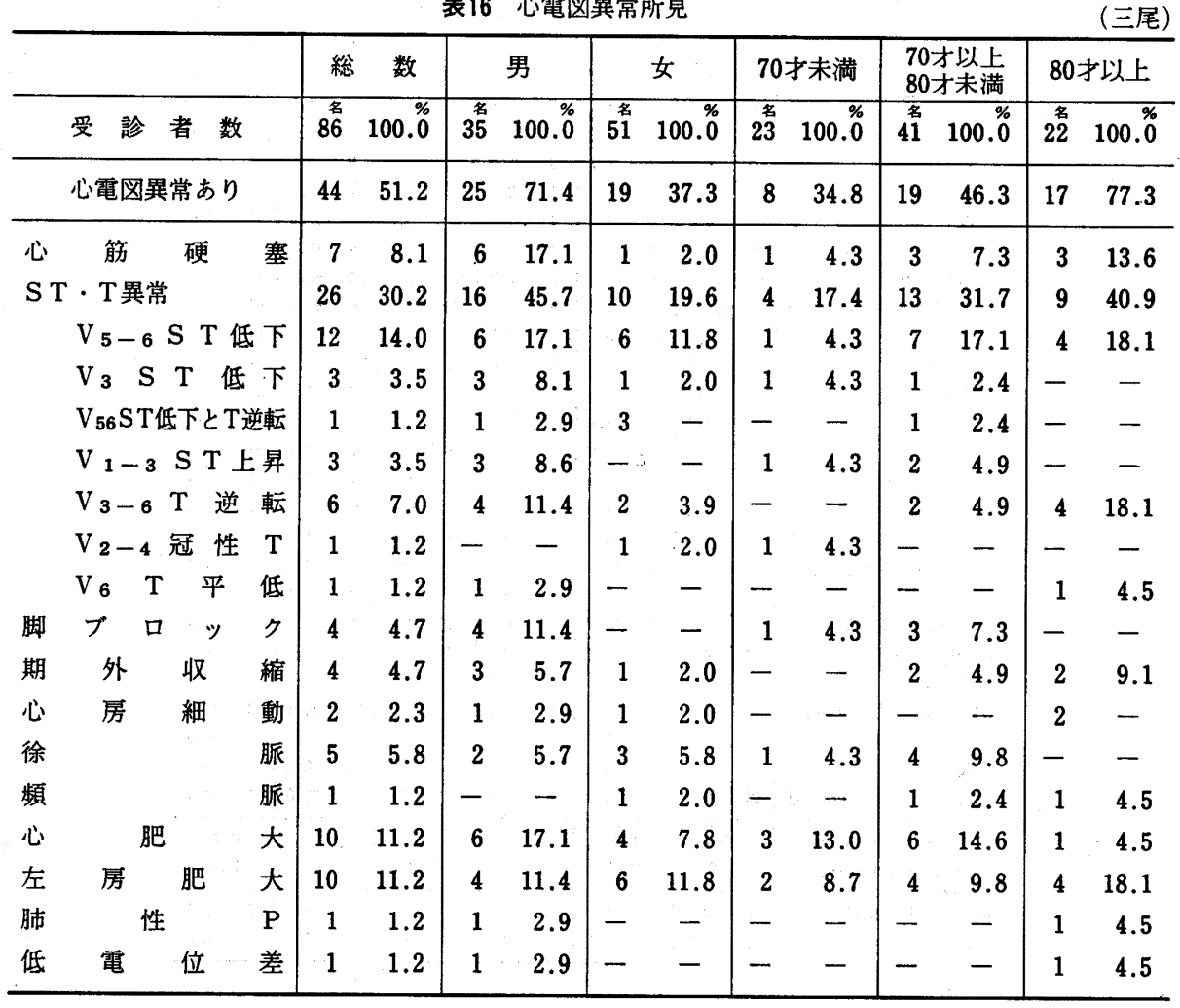


79名（男33名, 女46名）について血液検查をおこなっ た. (表15)

\section{1）全血比重（硫酸銅法による）}

低比重者 9 名, $11.4 \%$, 男（1.051以下） 7 名, 21.2 $\%$, 女（1.048以下） 2 名, 4.4\%. 男は女より高率な傾 向にあるが, 有意差でない。

\section{2）臨床化学検查}

各検査所見が，基準値より大または小の異常集をみと めたのは中性脂肪高值22名 (27.9\%), L D H 高值15名 (19.0\%)，無機燐の低值とむに 8 名(10.1\%), 血清鉄 低值 7 名 (8.9\%), 尿素窒素 7 名 (8.9\%), クレアチニ ン高值 4 名 $(5.1 \%)$ 等である. 性別, 年令別に有意差を みとめない（註 本稿第 1 篇 6 頁参照）

\section{4 循環器系疾患について}

\section{1) 心電図異常所見}

心電図異常所見あり44名，51.2\%もあった．男25名， $71.4 \%$ ，女19名， $37.3 \%$ ，男は女よりも有意们高率であ る（危険率 $1 \%$ 以下)，また 80 才以上 $(77.3 \%$ ）は80才未 満 (46.3\%)，及び70才未満 (34.8\%) に比べて高率で ある (危険率 $1 \%$ 以下で有意). 心電目異常所見の内容 は，表16のごとく，S TまたはT異常 26名，30.2\%あ り，そのうち V 5-6 S T低下 12 名，14.0\%である.心肥 大及び左房肥大各々 10 名, $11.6 \%$, 心筋硬塞 7 名, 8.1 \%がやや多い.ついで徐脈 5 名, 5.8\%, 脚ブロック， 期外収縮，ともに 4 名 $4.7 \%$ ，などがつゔく.

性別比較：男は女に比べて S T・T異常, 心筋硬塞及 び期外收維が有意に高率ある，心肥大るやや高率である が有意でない。

年令別比較：高令者ほど異常所見率が高い。とくに80 才以上の異常所見率77.3\%であり, 心筇硬塞, $\mathrm{S} \mathrm{T} ・ \mathrm{~T}$ の異常, 左房肥大などが高率である.

\section{2 ）高血圧症と心電図所見}

高血圧症をみとめた者 36 名のうち，心電四異常をみと めた者 25 名, 69.4\%. 非高血圧者 (50名中，心電四異常 をみとめた者 22 名 $44 \%$ ）に比べて有意に高率である（1 \%以下の危険率). 高血圧症は S T・Tの異常 $\left(\mathrm{V}_{5-6} \mathrm{~S}\right.$ T低下）と心肥大が比較的高率である.（表17）

\section{3）高血圧症と血液臨床化学検査結果}

高血圧を認めた者と認めなかったものの間仪臨床化学 検查結果には有位差をみとめない，L D H，尿素窒素が 高血圧者にやや高率であるが, 有意差でない（表18）.

\section{4) 心電図異常所見之血液臨床化学検査結果}

心電四異常所見の有無により，血液臨床化学検查所見 に有意差をみとめない。心筋硬塞と $\mathrm{V}_{5-6} \mathrm{~S} T$ 低下は $\mathrm{L}$ D H 高值が多い傾向があるが有意差ではない（表19）

\section{5) 循環器疾患と前職}

当地区の老人は長年にわたり漁業に従事し, またカナ ダ方面へ出稼ぎ移住体験者が多く, これらの前歷と循環 器疾患との関係を検討した。前職漁師の老人は漁師でな かった老人に比べて，5\%以下の危険率で高血圧症の有 病率が低小（ $(=2.450 ）($ 表20），心電四異常所見につ いては有意差をみとめない，また海外渡航経験の有無に よって, 高血圧症及び心電困異常発現に有意差をみとめ ない.

\section{5 健康診断事後措置の判定と受診状況}

健康診断の結果から判断した事後措置の区分は, 治療

表18 高血圧症の血液臨床化学娭査結果（三尾）

\begin{tabular}{|c|c|c|c|c|c|}
\hline & & \multicolumn{2}{|c|}{ 高血圧症 } & \multicolumn{2}{|c|}{ 非高血圧症 } \\
\hline 検 查 & 数 & & 100.0 & 47 & $100 . \%$ \\
\hline $\begin{array}{lll}G & O & T\end{array}$ & $\mathrm{H}$ & - & - & 1 & 2.1 \\
\hline G $\quad P \quad T$ & $\mathrm{H}$ & 1 & 3.1 & 2 & 4.3 \\
\hline$A$ L $P$ & $\mathrm{H}$ & 1 & 3.1 & 1 & 2.1 \\
\hline L $\quad \mathrm{D} \quad \mathrm{H}$ & $\mathrm{H}$ & 8 & 25.0 & 7 & 14.9 \\
\hline 総ビリルビン & H & 2 & 6.3 & - & - \\
\hline コレステロール & $\mathrm{H}$ & - & - & 1 & 2.1 \\
\hline 中性脂肪 & $\mathrm{H}$ & 9 & 28.1 & 13 & 26.7 \\
\hline 血 清 鉄 & $\mathrm{L}$ & 2 & 6.3 & 5 & 10.6 \\
\hline $\mathrm{N} \mathrm{a}$ & L & 1 & 3.1 & 2 & 4.3 \\
\hline $\mathrm{C} \ell$ & $\mathrm{L}$ & 2 & 6.3 & - & - \\
\hline $\mathrm{C}$ a & $\mathrm{L}$ & 2 & 6.3 & 6 & 12.8 \\
\hline 無 機 燐 & L & 4 & 12.5 & 4 & 8.5 \\
\hline 尿素堂素 & $\mathrm{H}$ & 5 & 15.6 & 2 & 4.3 \\
\hline 尿 & $\mathrm{H}$ & 1 & 3.1 & - & - \\
\hline クレアチニン & $\mathrm{H}$ & 4 & 12.5 & - & - \\
\hline 全血比重 & L & 5 & 15.6 & 4 & 8.5 \\
\hline
\end{tabular}

表17 高血圧症と心電図異常所見

\begin{tabular}{|c|c|c|c|c|c|c|c|c|c|c|c|c|c|c|}
\hline & 棇 数 & $\begin{array}{l}\text { 心電 図 } \\
\text { 異常あり }\end{array}$ & 心筋硬塞 & ST、T異常 & 明フロック & 不整脈 & 徐 & 脈 & 頻 & 服 & 心 肥 大 & 左房肥大 & 肺 性 P & 低電位差 \\
\hline 高血圧昰 & $36 \quad 100.0$ & $\begin{array}{ll}\text { 名 } & 69.4\end{array}$ & $\begin{array}{ll}\% & 13.9 \\
\end{array}$ & $\begin{array}{|cc|}\% & \% \\
13 & 36.1 \\
\end{array}$ & $\begin{array}{|ll|}\text { 多 } & 2.8 \\
\end{array}$ & $\begin{array}{ll} & \$ \% \\
2 & 5.6\end{array}$ & 2 & 5.6 & 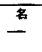 & $-\%$ & $\begin{array}{ll}\text { 多 } & 19.4 \\
\end{array}$ & $\begin{array}{|ll|}5 & 13.9 \\
\end{array}$ & $\begin{array}{ll}\text { क } & 2.8 \\
\end{array}$ & $\begin{array}{ll}\text { 名 } & 2.8 \\
\end{array}$ \\
\hline 非高血圧 & 50100.0 & 1938.0 & 4.0 & $\begin{array}{ll}13 & 26.0\end{array}$ & 6.0 & 8.0 & 3 & 6.0 & 1 & 2.0 & 6.0 & $5 \quad 10.0$ & - & - \\
\hline
\end{tabular}


表19 心電図異常者の血液踇床化学検查結果

(三尾)

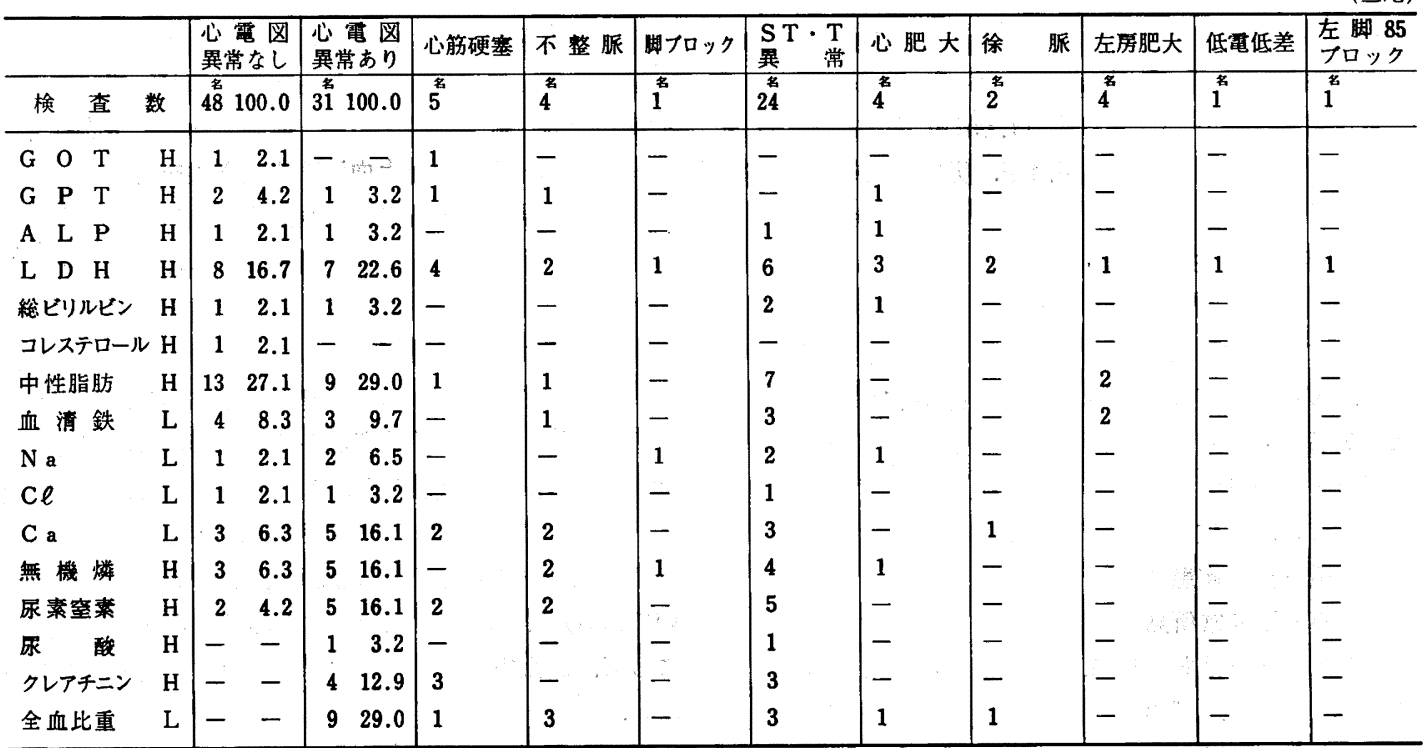

（註：総蛋白、アルフミン翼常值者なし）

表 21 老人健康診断・事後措置判定区分

（三尾）

\begin{tabular}{|c|c|c|c|c|c|c|c|c|c|c|c|c|c|c|}
\hline \multirow[b]{2}{*}{ 受検者数 } & \multicolumn{2}{|c|}{ 総 数 } & \multicolumn{2}{|r|}{ 男 } & \multicolumn{2}{|r|}{ 女 } & \multicolumn{2}{|c|}{ 70才未澫 } & \multicolumn{2}{|c|}{ 70才〜75才末満 } & \multicolumn{2}{|c|}{ 75才〜80才末满 } & \multicolumn{2}{|c|}{80 才以上 } \\
\hline & & 100.0 & 35 & 100.0 & 51 & 100.0 & 23 & $100 . \%$ & 20 & 100.0 & 21 & $100.0^{\%}$ & 22 & 100.0 \\
\hline 要 治 療 & 54 & 62.8 & 27 & 77.1 & 27 & 52.9 & 7 & 30.4 & 14 & 70.0 & 15 & 71.4 & 18 & 81.8 \\
\hline 要 指 療 & 22 & 25.6 & 7 & 20.0 & 15 & 29.4 & 11 & 47.8 & 4 & 20.0 & 4 & 19.0 & 3 & 13.6 \\
\hline 要 注 意 & 9 & 10.5 & 1 & 2.9 & 8 & 15.7 & 5 & 21.8 & 2 & 10.0 & 2 & 9.5 & - & - \\
\hline 所見なし & 1 & 1.2 & - & - & 1 & 2.0 & - & - & - & - & - & - & 1 & 4.5 \\
\hline
\end{tabular}

表22 健康診断判定区分と受診状況（三尾）

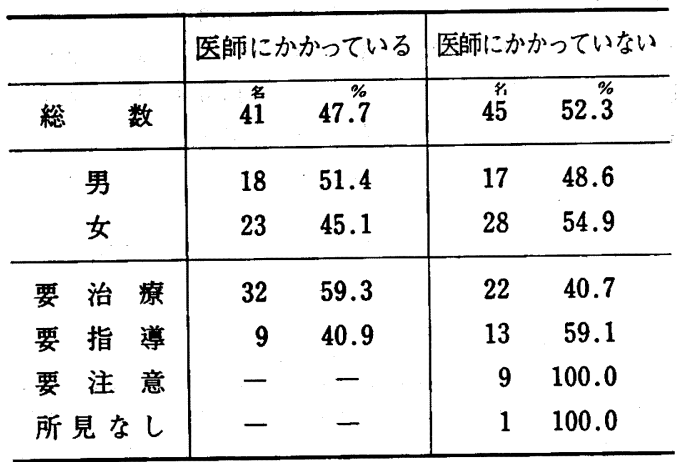

表20 前歴と循環器異常所見 (三尾)

\begin{tabular}{|c|c|c|}
\hline & 漁 師 & 非 漁 師 \\
\hline 調 査 数 & $15 \quad 100.0$ & $20 \quad 100.0$ \\
\hline 高 血 圧 & 26.7 & $13 \quad 65.0$ \\
\hline \multirow[t]{2}{*}{ 心電困異常 } & 66.7 & $15 \quad 75.0$ \\
\hline & 海外渡航者 & 非渡航者 \\
\hline 調 査 数 & $21 \quad 100.0$ & $\begin{array}{ll}4 & 100.0\end{array}$ \\
\hline 高 血 圧 & 47.6 & 50.0 \\
\hline 心電図異常 & 71.4 & 71.4 \\
\hline
\end{tabular}


的措置を要する者 54 名, $62.8 \%$, 健康観察, 生活指導を 要する者22名, 25.6\%である. 異常所見を有するが, と くに医療的措置を要しない者 9 名, $10.5 \%$, 所見なし 1 名, $1.2 \%$ である. 医師による治療措置または健療管理を 要すると判定された者のうち，健康診断当時，「医師に かかつている」と答えたものは，それぞれ59.3\%と40.9 タであり，「医師にかかつていない」ものは，それぞれ 40.7\%と59.1\%であった.（表21，22）

治療あるい健康管理を要する者は，多くは，何らか の病訴をもっていたにもかかわらず，その半数が医師に 受診していなかった.

すなわち，当地域における医療サービスの不足を示唆 し，また患者には「がまん型」が多いと思われる.

老人の医療と療養指導について格別な配虑を要する.

\section{IV，「長寿村」について}

三尾地区は「長寿村」と称される．老年人口の割合が 大きく，特に高年令者の割合が大きいためであろう．そ の理由について調査の結果, 青壮年期における転出と老 後钮郷が大いに関っていることが判った.

これに加えて，高令の老年者の死亡が期待值より少な いことをみとめた.

安倍は「漁業の多い町で，婦人の農業就業が多い所ほ ど長寿率が高い」の)という。もっとも，水島によれば， 「長寿率の大小は, 死亡率の高低を反映せず, 従って, その人口の健否の尺度とはなり得ない。......他の条件が 同じならば, ただ, 高年令の死亡率の低いことを示すに 過ぎ」10)という．漁業従事者の寿命については，三 上の報告11）をみると1955年当時，漁業は65才平均余命 9.36年であり, 有職業全体 (9.43年) よりやや短かい.

三尾地区では高令者の割合が大きく，65才以上人口の うち，75才以上人口の占める割合（「高令者率」の称す る）㤬国人口の 2 倍に近い.これには前述のごとく特 異な社会異動が関係する．あわせて高年者の死亡率が低 い可能性を認めた. この点については当地在住の保健婦 とヘルパーがかねてより老人の保健指導と介助活動を積 極的におこなっている事実，また当地が気候温暖な海岸
地域である（それ故にカナダ方面移住者が老後，帰郷す る風習がある）ことなどが，無医的状況であるにもかか わらず，老人保健に益している可能性が考えられる. 今 後の検討課題である.

なお当地区は老年化指数が異常に大きく，老化人口で あり，人口減少を続けるであろう.

\section{V，まとめ}

「長寿村」と俗称される和歌山県美浜町三尾地区（漁 村）における調査と健康診断の結果,

1 高令者の人口構成比が異常に大きい. また老年化 指数も異常に大きく「老化人口」である.

2 青壮年期に海外，特にカナダ方面に渡航し，老後 帰郷する風習がある，男の老人の $43 \%$ は㷌郷者である.

3 高令者の死亡は全国水準による期待值より少ない 可能性がある.

4 全国水準に比べて家族同居が少なく，老夫婦世帯 と女の独居世帯が多い.

5 狭少な居室が多いが，日当りなどの環境はよい。

6 一日のくらしは男は「働きごと」と「勝手なこと が相半ばし，女は「家庭の仕事」と「働きごと」があり， 「勝手なこと」が少ない。

7 無医状況の改善を要望している.

8 健康診断の結果, 病訴あり $84 \%$, 有所見者 $99 \%$, ほとんど何らかの異常所見がある，異常所見の種類は循 環器疾患有病率 $66 \%$ ，E C G 異常所見 $51 \%$ ，高血圧 $42 \%$ が多く，腰痛15\%，難聴14\%，貧血11\%などがつゔく。

9 判定区分任要治療63\%, 要指導 $26 \%$, 要注意 11 $\%$, 要治療者と要指導者の $46 \%$ は健診当時, 医師にかか っていない.「がまえ型」が多い。

10 地区在住の保健婦，一ルパーの継続的な活動が老 人保健を支え，無医状況を補っているようであるが，自 治体, 保健センターの活動, 近隣の主治医の巡回医療, 保健婦の地域看護と健康相談，へルパーの介助と援護な ど, 地域老人保健福祉対策を積極的にすすめる必要があ る. 


\section{第 3 篇 和歌山県一農村における老年者の健康， \\ 生活構造並びに意識に関する調查結果}

老年者の健康と生活構造ならびに意識に関する調査研 究の一環として, 和歌山県有田郡吉備町において調查を おこなった。

\section{吉備町の状況}

和歌山県有田郡吉備町は和歌山県の西部地域有田地方 の中心に位置し, 面積 $36.4 \mathrm{~km}^{2}$, 東西に有田川が貫流し, 丘陵にかこまれた田野であり，温暖な気候（年平均 15.6 “C）乙風土に恵まれ，有田みかて生産の本場である。最 近では養䳕業る伸び，農業近代化を遂げている．また伝 統産業として, 紀洲瓦製造と酒作りがある. 当町の産業 別世帯数は第 1 次産業 1,206 人，46\%を占め，第 2 次産 業565人，22\%．第 3 次産業839人，32\%（1970年国勢調 査). 1975年の農業センサスによると，専業農家33.9\%， 第 1 種兼業農家 $33.4 \%$ ，第 2 種兼業農家 $32.9 \%$ である. ひとくちにいえば，気候温暖な経済的に恵まれた農村地 域である.

吉備町の人口構成注 1980 年10月現在, 世帯数3, 233戸, 絵人口13, 077名(男 6,502 名，女6,575名).人口ピラミッ ドは別図のごとくであり，釣鐘型を呈する．年少人口 (10才〜14才) 2,771 名, 総人口の $21.1 \%$ ，生産年令人

吉備地区・人口構成

一性別・年令別一 (1980年10月)

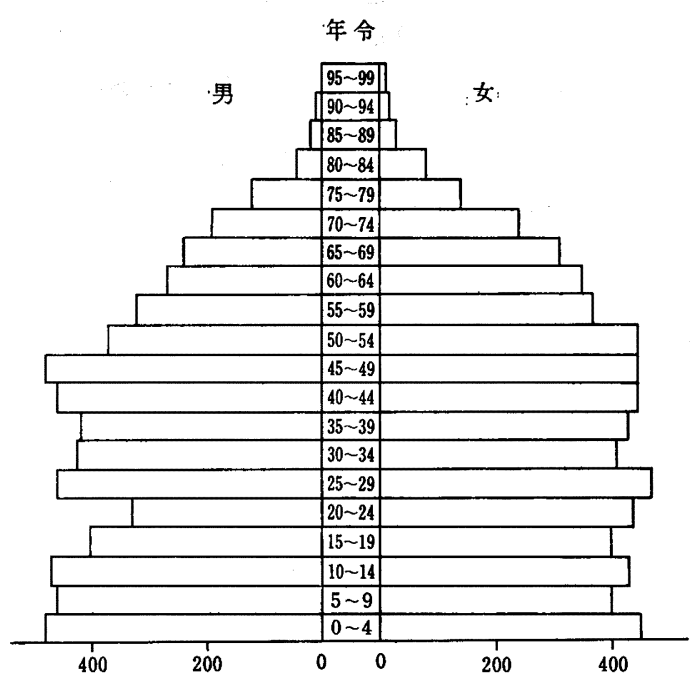

口 (15才〜 64才) 8,695名, 総人口の $66.5 \% ， 65$ 才以上 老年人口 1,746 名，総人口の $13.4 \%$ ある. 老年人口指 数20.1，老年化指数63.0であり，和歌山県人口および全 国人口に比べて老年人口の割合が大きい，高令者率 $\left(\frac{75 \text { 才以上人口 }}{65 \text { 才以上人口 }} \times 100,31.6\right)$ は全国人口（34.5）より も小さく，高令の老年者の割合は少ない.

\section{アンケート調查結果}

吉備町在住の65才以上老人を対象に 1979 年 7 月 9 月 の間にフンケート調査を行った. 調査対象は吉備町の各 区に，おおむ称人口比に応じて按分し，150名を任意抽 出した，回答123名，回答率82\%である.

\section{1 人口構成と世带類型}

男 56 名，女 67 名，年令構成はは 65 才以上 70 才未満 30 $\%$, 70才以上 75 才未満 $31 \%$ ，75才以上 80 才未満 $22 \% ， 80$ 才以上17\%である(表 1 ).

配偶関係：男は有配偶40名，71.4\% であるのにたい し，女は有配偶17名，25.4\%であり，著しい差がある。

世帯類型：家族と同居が95\%を占め，夫婦暮しと 1 人 暮しは各々 3 名，2.4\%にすぎない（表 2 ）

\section{2 年金亡医廉保険加入状況}

年金をうけているもの 112 名，91\%あり，その種類は， 老令年金80名（71.4\%）が大部分を占め，国民年金28名 (22.8\%)，厚生年金 ( 2 名, $1.6 \%)$ ，障害年金，恩給 （各1名，0.8\%）は少ない.

医療保険加入状況は国民保険加入者が多く113名，92 $\%$, 被用者医療保険は 6 名, $4.9 \%$ であり. 自費 2 名, $1.6 \%$ な打生活保護受給者は 2 名, $1.6 \%$ である.

\section{3 日常生活能力, ADL（表 3 ）}

自己判断による生活能力A D L は「自分でできないの で助けがいる」(要金介助) 5 名，4.1\%，「自分でもでき るが助けがいる」(要部分介助) 8 名, 6.5\%, 「不自由な ところがあるが自分でできる」(部分独立)23名, 18.9\%， 「不自由なく自分でできる」(全独立) 87名，70.7\%であ る. 要全介助者は男が 4 名, 女 1 名. 数は少ないが， 1 人暮し老人 3 名のうち 2 名は要全介助であり, ヘルパー の派遣，援助が必要である.

\section{4 日常生活 (表 4 )}

「日頃，主に何をしていますか」という問いにたいし 
表 1 老年者調査の対象

(吉備)

\begin{tabular}{|c|c|c|c|c|c|c|c|c|c|c|}
\hline \multirow[b]{2}{*}{ 棇 数 } & \multicolumn{2}{|c|}{ 65才〜75才未満 } & \multicolumn{2}{|c|}{ 70才末満 } & \multicolumn{2}{|c|}{ 70才〜75才未満 } & \multicolumn{2}{|c|}{ 75才〜80才末満 } & \multicolumn{2}{|c|}{80 才以上 } \\
\hline & 123 & 100.0 & $\begin{array}{r}\phi_{4} \\
37\end{array}$ & 30.1 & $\begin{array}{r}\phi_{1} \\
38\end{array}$ & $30 . \%$ & 27 & $21 . \%$ & 21 & 17.1 \\
\hline 男 & 56 & 100.0 & 16 & 28.6 & 19 & 33.9 & 10 & 17.9 & 11 & 19.6 \\
\hline 女 & 67 & 100.0 & 21 & 31.3 & 19 & 28.4 & 17 & 25.4 & 10 & 14.9 \\
\hline
\end{tabular}

表 2 老人の世帯類型

(吉備)

\begin{tabular}{|c|c|c|c|c|c|c|c|c|c|c|c|}
\hline \multirow{2}{*}{\multicolumn{2}{|c|}{ 調 査 数 }} & \multirow{2}{*}{$\begin{array}{r}\text { 総 } \\
123\end{array}$} & \multirow{2}{*}{$\frac{\text { 数 }}{100 \%}$} & \multicolumn{2}{|r|}{ 男 } & \multicolumn{2}{|r|}{ 女 } & \multicolumn{2}{|c|}{ 75才未満 } & \multicolumn{2}{|c|}{ 75才以上 } \\
\hline & & & & 56 & 100.0 & 67 & 100.0 & $\begin{array}{l}\hat{y}_{2} \\
75\end{array}$ & 100.0 & $\begin{array}{r}y_{1} \\
48\end{array}$ & 100.0 \\
\hline 配 & あ & 57 & 46.3 & 40 & 71.4 & 17 & 25.4 & 41 & 54.7 & 16 & 33.3 \\
\hline 偶 & & 63 & 51.2 & 13 & 23.2 & 50 & 74.6 & 31 & 41.3 & 32 & 66.7 \\
\hline 者 & 回答な & 3 & 2.4 & 3 & 5.4 & - & - & 3 & 4.0 & - & - \\
\hline \multicolumn{2}{|c|}{ 家族同居 } & 117 & 95.1 & 52 & 92.9 & 65 & 97.0 & 69 & 92.0 & 48 & 100.0 \\
\hline \multicolumn{2}{|c|}{ 夫婦暮 し } & 3 & 2.4 & 3 & 5.4 & - & - & 3 & 4.0 & - & - \\
\hline \multicolumn{2}{|c|}{ 一人暮 し } & 3 & 2.4 & 1 & 1.8 & 2 & 3.0 & 3 & 4.0 & - & - \\
\hline
\end{tabular}

表 3 老人の日常生活能力 A D L

(吉備)

\begin{tabular}{l|rr|rr|rr|rr|rr}
\hline & \multicolumn{2}{|c|}{ 総 } & 数 & \multicolumn{2}{|c|}{ 男 } & \multicolumn{2}{|c|}{ 女 } & \multicolumn{2}{|c|}{ 75才未満 } & \multicolumn{2}{|c}{75 才以上 } \\
\hline 調 查 数 & 123 & 100.0 & 56 & 100.0 & 67 & 100.0 & 75 & 100.0 & 48 & 100.0 \\
\hline 要 全介助 & 5 & 4.0 & 4 & 7.1 & 1 & 1.5 & 3 & 4.0 & 2 & 4.2 \\
部 分介助 & 8 & 6.5 & 4 & 7.1 & 4 & 5.9 & 4 & 5.3 & 4 & 8.3 \\
部 分独立 & 23 & 18.7 & 12 & 21.4 & 11 & 16.4 & 11 & 14.7 & 12 & 25.0 \\
全 独立 & 87 & 70.7 & 36 & 64.3 & 51 & 76.1 & 57 & 76.0 & 30 & 62.5 \\
\hline
\end{tabular}

表 4 老人の日常生活

（吉備）

\begin{tabular}{|c|c|c|c|c|c|c|c|c|}
\hline & \multicolumn{2}{|c|}{ 男 } & \multicolumn{2}{|c|}{ 女 } & \multicolumn{2}{|c|}{ 75才未満 } & \multicolumn{2}{|c|}{75 才以上 } \\
\hline 調 査 数 & $\begin{array}{r}\text { 名 } \\
56\end{array}$ & $100 . \%$ & 67 & 100.0 & 75 & 100.0 & $\begin{array}{r}y_{1} \\
48\end{array}$ & 100.0 \\
\hline つ と め & 1 & 1.8 & 2 & 2.9 & 3 & 4.0 & - & - \\
\hline 家業手伝い & 16 & 28.6 & 6 & 8.9 & 15 & 20.0 & 7 & 14.6 \\
\hline 田畑の仕事 & 39 & 69.6 & 14 & 26.9 & 36 & 48.0 & 17 & 35.4 \\
\hline 家 & 6 & 10.7 & 42 & 62.7 & 34 & 45.3 & 14 & 29.2 \\
\hline 孫 & 2 & 3.6 & 11 & 16.4 & 8 & 10.7 & 5 & 10.4 \\
\hline つれあいの世話 & - & - & 1 & 1.5 & 1 & 1.3 & - & - \\
\hline 庭の手入れ & 5 & 12.5 & 6 & 8.9 & 7 & 9.3 & 4 & 8.3 \\
\hline 何もしていない & 7 & 12.5 & 8 & 11.9 & 3 & 4.0 & 4 & 8.3 \\
\hline の & 1 & 1.8 & - & - & 6 & 8.0 & 1 & 2.1 \\
\hline
\end{tabular}


重複回答があるが，男の39名，70\%は「田畑の仕事」に従 事すると答光, 家事 3 名， $5 \%$, 勤め, 家業手伝い, 各 々1名，2\%である.すなわち大部分はなにか「する仕 事がある」，女は67名のうち家事43名，64\%，田畑の仕 事13名，19\%．子守り 4 名，6\%. 勤め1名，1.5\%な ぞ，家事関係を主とし「する仕事があり」，「何むしてい ない」という回答は男 7 名 (12.5\%)，女7名 (10.4\%) にすぎない。

\section{5 食生活}

食事の用意：男は「家族が作る」91\%，女は「家族が つくる」64\%，「自分がつくる」34\%，「家族がもって くる」男 3 名にある. 苦情はほとんどない.

\section{摂取食品}

主食 : 米飯のみが93\%を占め, 米とパン混食（6名） $5 \%$ にすぎない.

副食物の種類：「毎日食べる食品」は男の場合，魚 $98 \%$ と野菜 $75 \%$ を主とし，肉11\%，卵20\%，牛乳18\%，海草 $25 \%$ ，女は野菜94\%と魚 $39 \%$, 卵19\%，肉16\%の混合で あり，牛乳13\%，海草12\%等である。「稀にしか食べな い食品」は性差をほとんどみとめず，インスタント食品 $23 \%$, バター20\%, 八ム, ソーセージ20\%, 牛乳14\%等 である.（表 5)

\section{6 住居と入浴}

「いつるいる部屋」の規模は 6 蛅 $44 \% ， 8$ 帖以上 $49 \%$ であり，4.5帖以下は $8 \%$ である. 日常起居する居宅は 比較的大きいといえる.
入浴：毎日入る，79\%，2 日に 1 回入る $14 \% ， 3$ 日に 1 回入る $4 \%$ であり，入浴には不自由していないようで ある.

\section{7 人閶関係}

「家族関係」はほとえど全員116名，94\%がうまくいっ ていると答えている，また107名, 87\%は家族による世話 をうけ，「よくしてくれる」という。ただし「家族がよ くしてくれない」が 3 名ある.

88\%が老人クラブに入っている.

「近所ゔきあいはよく話しあう75\%，時々話す程度 19\%であり，近隣との交流はおおむねよいとみられる。

\section{8 愁訴と受療状況}

なんらかの愁訴があるもの 50 名, $40.6 \%$ ，心臟・脈管 系の訴えがもっとも多く，とくに血圧が高い21名，17.1 \%ある. つづいて, 神経痛17名, $13.8 \%$, 腰痛 6 名, 49 \%など, 疼痛の訴光が多い, 胃腸の具合が悪い 4 名, 他 は表のごとくである.（衰 6)

受診状況：医者にかかっている41名, 37.3\%。おおむ ね愁訴率に近い. 医者にかかっていない77名，62.6\%， 性差をみとめない（表 7)

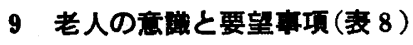

1) 困っていること

「病気がある」35名，28.5\%，「健康がすぐれない」 8 名, $6.5 \%$ あり, 約 $1 / 3$ は病気や不健康をかこっている.

「話相手がいない」6名 (4.9\%)，「近くに話しあえ る人がない」 4 名（3.2\%）など, 孤独感を表明し，「手

表 5 副食物の種類

(吉備)

\begin{tabular}{|c|c|c|c|c|c|c|c|c|c|c|}
\hline & & & \multicolumn{4}{|c|}{ 毎日食べる食品 } & \multicolumn{4}{|c|}{ 稀にしか食べない食品 } \\
\hline & & & \multicolumn{2}{|r|}{ 男 } & \multicolumn{2}{|c|}{ 女 } & \multicolumn{2}{|c|}{ 男 } & \multicolumn{2}{|r|}{ 女 } \\
\hline 調 & \multicolumn{2}{|l|}{ 査 } & 56 & 100.0 & 67 & $100 . \%$ & 56 & $100 . \%$ & 67 & 100.0 \\
\hline \multicolumn{3}{|c|}{ 魚 } & 55 & 98.2 & 26 & 38.8 & - & - & 1 & 1.5 \\
\hline \multicolumn{3}{|c|}{ 肉 } & 6 & 10.7 & 11 & 16.4 & 1 & 1.8 & 3 & 4.5 \\
\hline \multicolumn{3}{|c|}{ 卵 } & 11 & 19.6 & 13 & 19.4 & 2 & 3.6 & 3 & 4.5 \\
\hline 牛 & & 乳 & 10 & 17.9 & 9 & 13.4 & 7 & 12.5 & 10 & 14.9 \\
\hline バ & 夕 & - & - & - & - & - & 10 & 17.9 & 15 & 22.4 \\
\hline \multicolumn{3}{|c|}{ ハム・ソーセージ } & - & - & - & - & 12 & 21.4 & 12 & 17.9 \\
\hline \multicolumn{3}{|r|}{$\exists$} & 3 & 5.4 & 4 & 5.9 & 4 & 7.1 & 7 & 10.5 \\
\hline \multicolumn{3}{|l|}{ 野 } & 42 & 75.0 & 63 & 94.0 & - & - & - & - \\
\hline \multicolumn{3}{|c|}{ 海草 } & 14 & 25.0 & 8 & 11.9 & 2 & 3.6 & - & - \\
\hline \multicolumn{3}{|c|}{ インスタント食品 } & - & - & - & - & 11 & 19.6 & 17 & 25.4 \\
\hline
\end{tabular}


表 6 愁訴

\begin{tabular}{|c|c|c|c|c|c|c|c|c|c|c|}
\hline & 総 & 数 & \multicolumn{2}{|c|}{ 男 } & \multicolumn{2}{|c|}{ 女 } & \multicolumn{2}{|c|}{ 65才〜75才未満 } & \multicolumn{2}{|c|}{75 才以上 } \\
\hline 調 查 数 & $\begin{array}{r}\text { 名 } \\
123\end{array}$ & 100.0 & $\begin{array}{r}\text { 多 } \\
56\end{array}$ & $100 . \%$ & $\begin{array}{r}\psi_{11} \\
67\end{array}$ & 100.0 & 75 & 100.0 & $\begin{array}{r}\phi_{1} \\
48\end{array}$ & $100 \%$ \\
\hline 訴へある者 & 48 & 39.0 & 23 & 41.1 & 25 & 37.3 & 32 & 42.7 & 16 & 33.3 \\
\hline 心臓が悪い & 2 & 1.6 & 2 & 3.6 & - & - & 1 & 1.3 & 1 & 2.1 \\
\hline 血圧が高い & 21 & 17.0 & 7 & 12.5 & 14 & 20.9 & 11 & 14.7 & 10 & 20.8 \\
\hline 血圧が低い & 1 & 0.8 & - & - & 1 & 1.5 & 1 & 1.3 & - & - \\
\hline 見えにくい & 1 & 0.8 & 1 & 1.8 & - & - & -81 & - & 1 & 2.1 \\
\hline 白 内 障 & 1 & 0.8 & - & - & 1 & 1.5 & 1 & 1.3 & - & - \\
\hline 神 経 痛 & 1 & 0.8 & - & - & 1 & 1.5 & - & - & 1 & 2.1 \\
\hline 胃が悪い & 2 & 1.6 & 1 & 1.8 & 1 & 1.5 & 1 & 1.3 & 1 & 2.1 \\
\hline 便 & 2 & 1.6 & 1 & 1.8 & 1 & 1.5 & - & - & - & - \\
\hline 鼻つまり & 1 & 0.8 & 1 & 1.8 & - & - & 1 & 1.3 & - & - \\
\hline 喘 & 2 & 1.6 & 1 & 1.8 & 1 & 1.5 & - & - & 2 & 4.2 \\
\hline 肺 気 腫 & 1 & 0.8 & 1 & 1.8 & - & - & 1 & 1.3 & - & - \\
\hline 腰 & 6 & 4.9 & 2 & 3.6 & 4 & 5.9 & 5 & 6.7 & 1 & 2.1 \\
\hline 関 節 痛 & 4 & 3.3 & 4 & 7.1 & - & - & 3 & 4.0 & 1 & 2.1 \\
\hline 膝蓋水腫 & 1 & 0.8 & - & 一 & 1 & 1.5 & 1 & 1.3 & - & - \\
\hline じんましん & 2 & 1.6 & 1 & 1.8 & 1 & 1.5 & 1 & 1.3 & 1 & 2.1 \\
\hline 外 & 2 & 1.6 & 1 & 1.8 & 1 & 1.5 & 1 & 1.3 & 1 & 2.1 \\
\hline
\end{tabular}

表 7 受 療 状 況

（吉備）

\begin{tabular}{|c|c|c|c|c|c|c|c|c|c|c|c|c|}
\hline & & \multirow[b]{2}{*}{ 数 } & \multirow{2}{*}{\multicolumn{2}{|c|}{$\begin{array}{rc}\text { 総 } & \text { 数 } \\
12 \% & 100 \%\end{array}$}} & \multicolumn{2}{|r|}{ 男 } & \multicolumn{2}{|c|}{ 女 } & \multicolumn{2}{|c|}{ 65才〜75才未渾 } & \multicolumn{2}{|c|}{ 75才以上 } \\
\hline & & & & & 56 & 100.0 & $\begin{array}{r}\text { 名 } \\
67\end{array}$ & 100.0 & $\begin{array}{r}\text { 名 } \\
75\end{array}$ & 100.0 & $\begin{array}{r}\text { 名 } \\
48\end{array}$ & $100 . \%$ \\
\hline \multicolumn{3}{|c|}{ 医者にかかっている } & 41 & 33.3 & 17 & 30.3 & 24 & 35.8 & 23 & 30.7 & 18 & 37.5 \\
\hline \multicolumn{3}{|c|}{ 医者にかかっていない } & 77 & 62.6 & 36 & 64.3 & 41 & 61.2 & 48 & 64.0 & 29 & 60.4 \\
\hline 無 & 回 & 答 & 5 & 4.0 & 3 & 5.4 & 2 & 3.0 & 4 & 5.3 & 1 & 2.1 \\
\hline
\end{tabular}


表 8 老人の望

（吉備）

\begin{tabular}{|c|c|c|c|c|c|c|c|c|c|c|c|}
\hline & & & & & 男 & & 女 & & 未満 & & 以上 \\
\hline & 査 数 & & 100.0 & 56 & 100.0 & 67 & 100.0 & & 100.0 & & 100.0 \\
\hline $\begin{array}{l}\vdots \\
\iota\end{array}$ & 年金を增加してほしい & 25 & 20.3 & 10 & 17.9 & 15 & 22.0 & 13 & 17.3 & 12 & 25.0 \\
\hline 健 & 病気が治ってほしい & 22 & 17.9 & 9 & 16.1 & 13 & 19.4 & 16 & 21.3 & 6 & 12.5 \\
\hline 康 & 達者になりたい & 16 & 13.0 & 7 & 12.5 & 9 & 13.4 & 12 & 16.0 & 4 & 8.3 \\
\hline & 親切な医者がほしい & 18 & 14.6 & 8 & 14.3 & 10 & 14.9 & 14 & 18.7 & 4 & 8.3 \\
\hline 医 & あうメガネがほしい & 5 & 4.1 & 2 & 3.6 & 3 & 4.5 & 3 & 4.0 & 2 & 4.2 \\
\hline & 温泉へ行きたい & 5 & 4.1 & 3 & 5.4 & 2 & 3.0 & 3 & 4.0 & 2 & 4.2 \\
\hline & 歯医者にかかりたい & 4 & 3.3 & 1 & 1.8 & 3 & 4.6 & 4 & 5.3 & - & - \\
\hline & マッサージしてほしい & 2 & 1.6 & 1 & 1.8 & 1 & 1.5 & 2 & 2.7 & - & - \\
\hline 療 & ハリしてほしい & 1 & 0.8 & 1 & 1.8 & - & - & 1 & 1.3 & - & - \\
\hline & 医師に見てもらいたい & 1 & 0.8 & 1 & 1.8 & - & - & 1 & 1.3 & - & - \\
\hline 長 & 長生きしたい & 48 & 39.0 & 24 & 42.9 & 24 & 35.8 & 31 & 41.3 & 17 & 35.4 \\
\hline き & 長生きしたくない & 2 & 1.6 & - & - & 2 & 3.0 & 2 & 2.7 & - & - \\
\hline
\end{tabular}

助けしてくれる人がほしい」2名，「家事が負担である」 2名,「仕事がきつい」1名, というものがある反面, 「する仕事がない」（4名）と無聊をかこっている.

\section{2) 要望事項}

「年金を増加してほしい」25名, 20\%。「病気が治っ

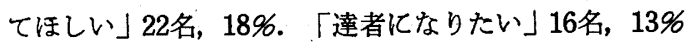
あり，約 $1 / 3 か ゙$ 健康にたいする願望を表明している．医療 については18名（14.6\%）が「親切な医者がほしい」と いいまた「歯医者にかかりたい」が4名，(3.3\%) ある.

温泉 ( 5 名), マッサージ (2名), 、リ（1名）等に 対する要望もある．これ等の要望事項はいちじるしい性 差をみとめないが，75才未満は75才以上に比べて健康や 医療に関する要望を表明するものが比較的多い.

\section{考察}

和歌山県吉備町は周囲の山畑がみかえ畑であり, 近年 水田もみかん畑に転作し, 農業経営も機械化が進えでい る。青壮年令層は近隣の会社, 工場に通勤し, 朝夕, 日 曜，祝祭日に農耕をするようになり，したがって留守を する老年層が畑仕事の主役となっている.

高令者比率はほほ全国平均に近く, 和歌山県平均より やや低い.

65 才以上老人 123 名にたいするアンケート調查の結果
1. 家族同居が全体の95\%を占め，「孤老」は少ない．

2. 要介助者 $11 \%$ あり，要全介助者 5 名 $(4.1 \%)$ の うち 3 名は「独り暮し老人」である.

3. 日常のくらしは, 主に男は田畑の仕事，女は家事 と田畑の仕事がある。「何もしていない」は少い。

主食は米飯が多く, 副食物は, 男は魚と野菜, 女は野 菜をよく食べ, 若干の性差がある. 約半数は牛乳をほと んどのまない，住居，入浴は不自由していないようであ る.

4. 愁訴率 $41 \%$ ，高血圧者がその $42 \%$ ，つゔいて神経 痛，腰痛が多い。受診率37\%は比較的低いが，なお「親 切な医者をもとめている」ものがかなりある (15\%).

5. 農村老人は「家族同居」が多く，「独居老人」が 少なく，「孤老化」から免れている。また日々田畑の 仕事」「家事，などのする仕事」があるるのが多く，日 常生活では不満が比較的少ないようである. その反面, 受診率37\%は比較的低く，「親切な医者がほしい」とい う要求がかなりある.

6. 「年金をふやしてほしい」, 老人いこいの家の設 置, 老人クラブ国庫補助，老人医療費支給，などの要望 がある.な抄数ながら，「独り暮し老人」に要全介助者 が存在していることはみのがせない，農村においても独 居老人の介助はゆるがせにできない。 


\section{まとめ}

和歌山県吉備町おいて65才以上の老年者について調査 した結果,

1. 世帯類型：家族同居95\%，孤老が少ない。

2. 日常生活：男注田畑之家業，女嫁庭の仕事と田 畑の仕事でほぼ満されている. その反面, 労働がきつい というものがある.

3. 日常生活能力 ADL : 介助を要する者 $11 \%$, 要全 介助 $4 \%$, 一人暮し老人に多い.
4. 健康状態と医療状沉：愁訴を有する者 $41 \%$ ，その 42\%は高血圧症, 神経痛, 腰痛, 心臓がわるいなどがつ づく.

5. 受診率37\%，達者になりたい18\%，病気が治りた い13\%，親切な医者がほしい15\%，他に歯医者にかかり たい，温泉にゆきたいなどの要求がある.

農村では一般に受診率が低く，「気ゔかず型」「がま え型」の潜在患者が存在する可能性が大きく，医療サー ビスの普及と健康診断, 健康相談などの日常的な健康管 理と労働負担の軽減が老人保健対策として重要である. 


\section{第 4 編＼cjkstart老年者の健康と生活構造並びに意識に 関する調査研究一地域比較と考察}

\section{調查対象地域の事情と人口構成}

大阪府守口市, 和歌山県日高郡美浜町三尾地区及び和 歌山県有田郡吉備町について, それぞれ地域事情と人口 構成の特殊性について述べると, 守口市は大阪市に北接 し，住民は勤労者階層を主とする混合住居地域であり， この老年者調查の対象者, 男の前職はブルーカラーが過 半数を占めている. 65 才以上人口 $6.9 \%$ あ゙あ, 全国大 都市全みである。

三尾地域は和歌山県西部海岸の漁村である. 65才以上 人口は $24.9 \%$ を占め, 高令者がとくに多く, 65 才以上人 口中，75才以上が $48 \%$ である. 調查対象者中，男の半数 は前職が漁師であり，また $43 \%$ は海外出稼ぎ渡航し，老 後, 帰郷した者である.
吉備町は有田みかんの本場であり, 調査対象者の過半 数は農業従事者である. 65才以上の人口 $18.5 \%$ ，65才以

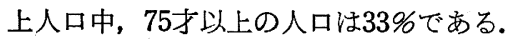

\section{I．アンケート調查結果の地域比較}

\section{1. 配偶関係・世帯類型（図 1，表 1）}

3 地域とも有配偶率に性差がある.男は $70 \sim 80 \%$ が有 配偶であるのにたいして，女の有配偶は守口 $33 \%$ ，三尾 は $38 \%$. 吉備 $25 \%$ である.

吉備（農村）の老人は95\%が家族同居であるのにたい して, 守口 (都市) では家族同居55\%, 三尾（鮘村）で は41\%であり，顕著な差がある. 守口と三尾は夫婦暮し と「 1 人暮し」の割合が大きく，とくに三尾では 1 人暮

図 1 老人の家族構成

配偶者の有無

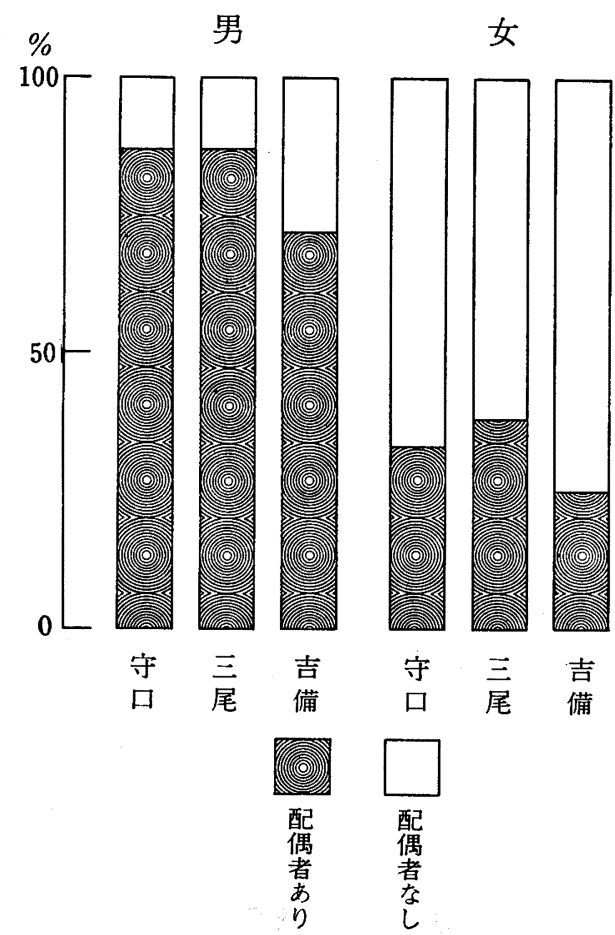

世 帯 類 型

男

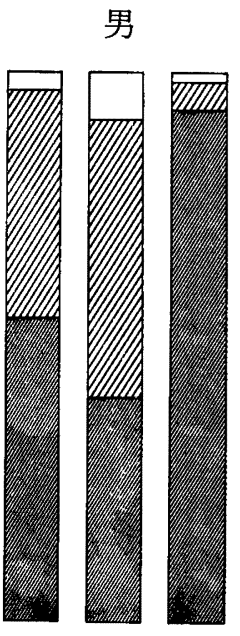

守

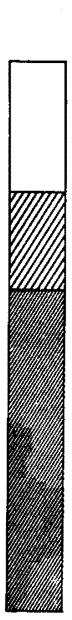

女
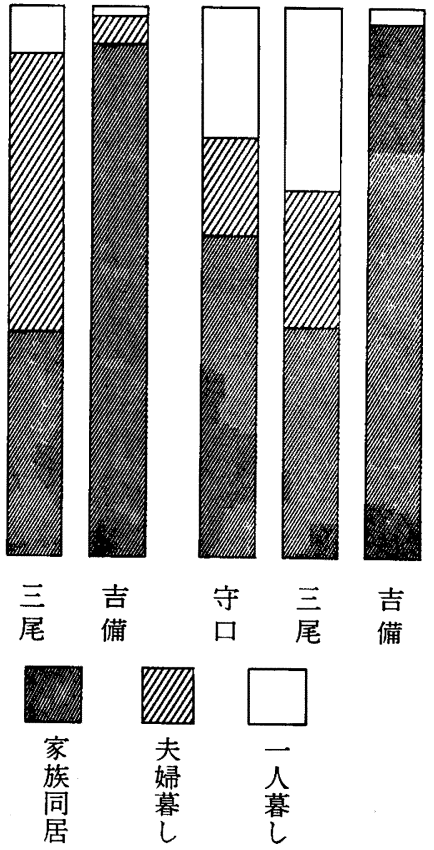
表 1 老年者の健康・生活構造・意識に関する調査 一地域比較・その 1 -

\begin{tabular}{|c|c|c|c|c|c|c|c|c|}
\hline \multicolumn{2}{|c|}{ 地 域 名 } & 守 & 口 & 三 & 尾 & 吉 & 備 & 備 \\
\hline \multicolumn{2}{|c|}{ 性 } & \multicolumn{2}{|c|}{ 都市(混合住居地域) } & \multicolumn{2}{|c|}{ 臨海地区(漁業) } & 農 & 村 & \\
\hline \multicolumn{2}{|c|}{ 人 } & $\begin{array}{r}164,817 \\
\text { ) }\end{array}$ & 100.0 & $\begin{array}{r}2) \\
878\end{array}$ & 100.0 & $\begin{array}{r}3 \text { 3) } \\
13,077\end{array}$ & 100.0 & \multirow{2}{*}{$\begin{array}{l}1 \text { ) } 1980 \text { 年 } 1 \text { 月 } \\
\text { 2) } 1979 \text { 年 } 12 \text { 月 } \\
\text { 3) } 1980 \text { 年 } 10 \text { 月 }\end{array}$} \\
\hline \multicolumn{2}{|c|}{ 65才以上人口 } & $11,453^{8}$ & 6.9 & $21 \stackrel{y_{1}}{9}$ & 24.9 & 1,611 & 12.3 & \\
\hline \multicolumn{2}{|c|}{ 老年人口指数 } & \multicolumn{2}{|c|}{10.7} & \multicolumn{2}{|c|}{41.7} & \multicolumn{2}{|c|}{18.5} & $\frac{65 \text { 求以上人口 }}{\text { 生壁年人口 }} \times 100$ \\
\hline \multicolumn{2}{|c|}{ 高 令 者 率 } & \multicolumn{2}{|c|}{29.7} & \multicolumn{2}{|c|}{47.7} & \multicolumn{2}{|c|}{33.2} & $\frac{75 \text { 才以上人口 }}{65 \text { 才以上人口 }} \times 100$ \\
\hline \multicolumn{2}{|c|}{ アンケート調査人数 } & 209 & 100.0 & $191^{4}$ & 100.0 & $123^{\gamma_{1}}$ & 100.0 & \\
\hline \multirow{2}{*}{\multicolumn{2}{|c|}{$\begin{array}{l}\text { 男 } \\
\text { 女 }\end{array}$}} & 86 & 41.1 & 76 & 39.8 & 56 & 45.5 & \\
\hline & & 123 & 58.9 & 115 & 60.0 & 67 & 54.5 & \\
\hline \multicolumn{2}{|c|}{ 65～70才未満 } & 82 & 29.2 & 37 & 27.2 & 37 & 30.1 & \\
\hline \multicolumn{2}{|c|}{ 70～80才未満 } & 102 & 48.8 & 65 & 46.0 & 65 & 52.9 & \\
\hline \multicolumn{2}{|c|}{80 才以上 } & 25 & 12.0 & 21 & 26.7 & 21 & 17.1 & \\
\hline & 男 & $74 / 86$ & $(86.5)$ & $66 / 76$ & $(86.8)$ & $40 / 56$ & $(71.4)$ & （）有配偶者率 \\
\hline & 女 & $41 / 123$ & $(33.3)$ & $44 / 115$ & $(38.3)$ & $17 / 67$ & $(25.4)$ & \\
\hline \multirow{3}{*}{ 男 } & 家族同居 & 47 & 54.7 & 31 & 40.8 & 52 & 92.9 & \\
\hline & 夫婦暮し & 36 & 41.9 & 38 & 50.0 & 3 & 5.4 & \\
\hline & 1 人暮し & 3 & 3.5 & 7 & 9.2 & 1 & 1.8 & \\
\hline \multirow{3}{*}{ 女 } & 家族同居 & 72 & 58.5 & 48 & 41.7 & 65 & 97.0 & \\
\hline & 夫婦暮し & 21 & 18.1 & 29 & 25.2 & - & - & \\
\hline & 1 人暮し & 30 & 24.4 & 38 & 33.0 & 2 & 3.0 & \\
\hline \multirow{4}{*}{$\begin{array}{l}\text { 日 } \\
\text { 常 } \\
\text { 生 } \\
\text { 活 } \\
\text { 能 } \\
\text { 力 }\end{array}$} & 全介助 & 6 & 2.9 & 14 & 7.3 & 5 & 4.0 & \\
\hline & 部分介助 & 5 & 2.4 & 11 & 5.8 & 8 & 6.5 & \\
\hline & 部分独立 & 28 & 13.4 & 30 & 15.7 & 23 & 18.7 & \\
\hline & 全 独立 & 165 & 78.9 & 126 & 66.0 & 87 & 70.7 & \\
\hline \multicolumn{2}{|c|}{ 年金受 給者 } & 182 & 87.1 & 175 & 91.6 & 112 & 91.0 & \\
\hline \multirow{4}{*}{\multicolumn{2}{|c|}{ 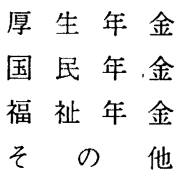 }} & 91 & 43.5 & - & - & 2 & 1.6 & \\
\hline & & - & - & 49 & 25.7 & 28 & 22.8 & \\
\hline & & 56 & 26.8 & 89 & 46.6 & 80 & 71.4 & \\
\hline & & 13 & 6.2 & $17(15)$ & $8.9(7.0)$ & 2 & 1.6 & （ ）カナダ年金 \\
\hline \multirow{3}{*}{\multicolumn{2}{|c|}{$\begin{array}{l}\text { 国 保 } \\
\text { 被用者保険 } \\
\text { 生活保護受給 }\end{array}$}} & 127 & 60.8 & 145 & $75: 9$ & 113 & 91.6 & \\
\hline & & 57 & 27.3 & 32 & 16.8 & 6 & 4.9 & \\
\hline & & 5 & 22.4 & 3 & 1.6 & 2 & 1.6 & \\
\hline
\end{tabular}


しが多い (23\%)，何れの地区でも 1 人暮しの大部分は 女であり，男は少い。

\section{2. 年金と医療保険加入状況（表 1)}

年金 : 老人の生計には年金が欠かせない，各地区共に 年金受給者は $90 \%$ 前後である. その種類は，前職被用者 が多い守口では厚生年金受給者がその半数近く (44\%), $27 \%$ は福祉年金（月 2 万円強）である．吉備は農民を主 とし，福祉年金受給者が71\%を占め，国民年金 $23 \% ， 三$ 尾では前職漁師が半ば近く，福祉年金 $47 \% ，$ 国民年金26 $\%$ ，一部にその他の年金，恩給，カナダ年金受給者（15 名, $8 \%$ ）がある.

加入医療保険等の種類 : 各地区共に国保が大部分を占 める. とくに吉備は $91 \%$ が国保である. 守口は国保 61 $\%$, 被用者保険 $27 \%$ ，三尾汪国保 $76 \%$ ，被用者保険 $17 \%$ である.なお生活保護受給者は守口 $2.4 \%$ ，吉備，三尾 はともに1.6\%である.

\section{3. 老人の日常生活（表 2, 図 2）}

「日項，何をしていますか」という問いにたいする回 答は，複数回答であるが，

勤め，田畑，家業手伝いなどの「働きごと」，家事，育 児, つれあいの世話など「家庭の仕事」, 庭の手入れ, 散 歩，好きなととなど「勝手なとと」にまとめ，それぞれ， それらの累計において占める割合を\%でみると,男女差, 地域差が著明である．男の場合，守口は「働きごと」 25 \%，「勝手なこと」が60\%，にたいして，吉備では「働

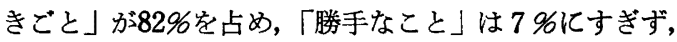
対照的である. 三尾では「働きごと」と「勝手なこと」 がほほ等しく44\%，何れの地域でも男は「家庭の仕事」 は10\%台である，女の場合，何れの地域でも「家庭の仕 事」が過半数を占めるが, 「働きごと」は三尾, 吉備,

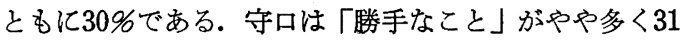
\%, 三尾これ次ぎ $17 \%$ ，吉備は $7 \%$ にすぎない，すな わち老女は各地域ともに主に「家事」に従事するが，守 ロでは「勝手なこと」がやや多い.

概してい光ば，農家の老人は田畑とのつながりがあ り，家族同居でああり，「働きでと」や「家の仕事」で 満ちている. 他方，身体をるとに働いてきた都市の老人 は，老後「家のこと」以外に特定の「働きごと」が少な く，無揤をかこつものが多い，漁村の老人は概ね前 2 者 の中間である. 老人の 1 日の暮し方が「生きがい」や意 識の根底にあるようである。

\section{4. 日常生活能力 ADL（表 1)}

老令化に伴い，心身の機能低下あるいは疾病により， 自立的生活能力が障害され，介助を要する者が増える. 当人の回答によると日常生活能力について，「介助を要
表 2 老人の生活構造

一日頃・していること一

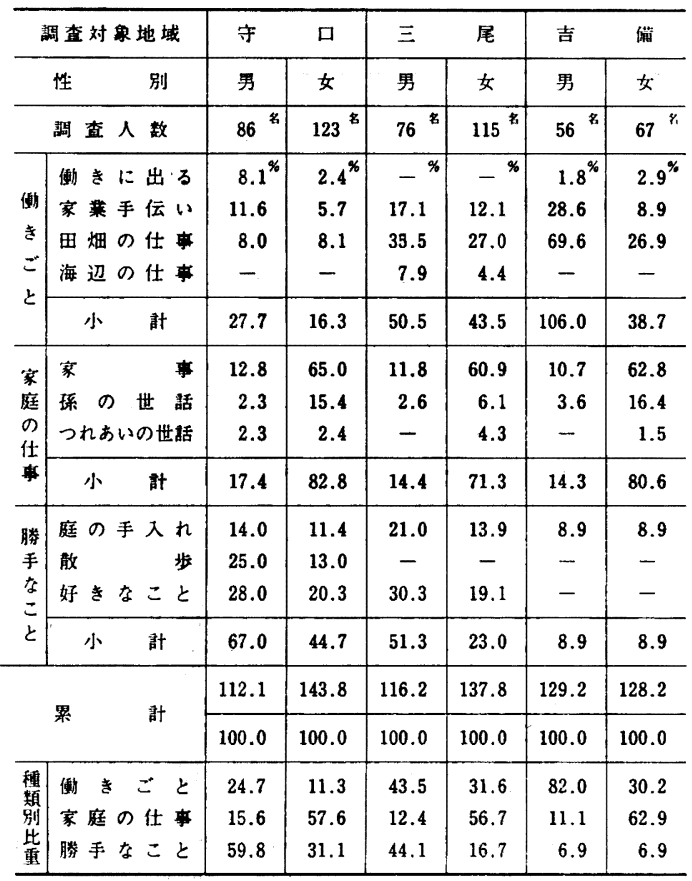

図 2 老人が日頃していること
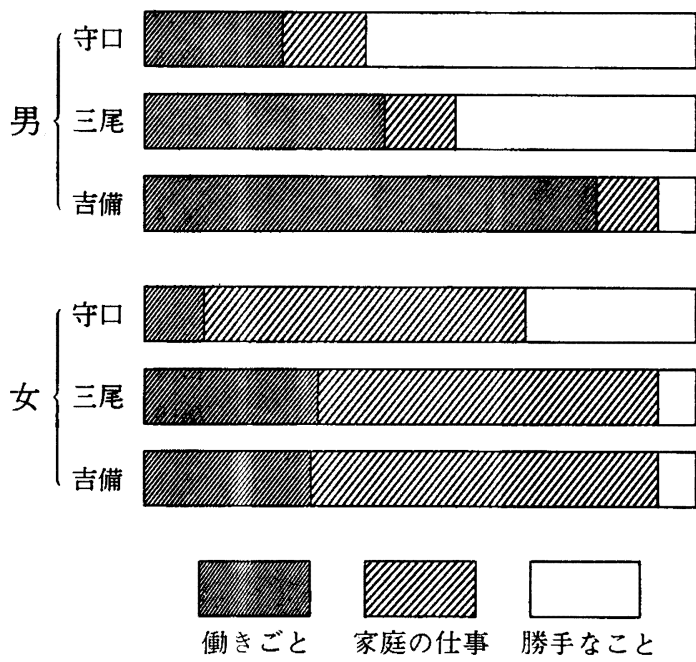

するもの」は，独居老人や高令者が多い三尾ではやや多 く14\%，吉備11\%これに次ぎ，守口がもっとも少なく 5 \%である.

\section{5. 食事について}

夫婦暮し老人と独居の老女は「食事は自分で作る」, 家族同居の多い吉備ではほとんどが「家族が作る」. 


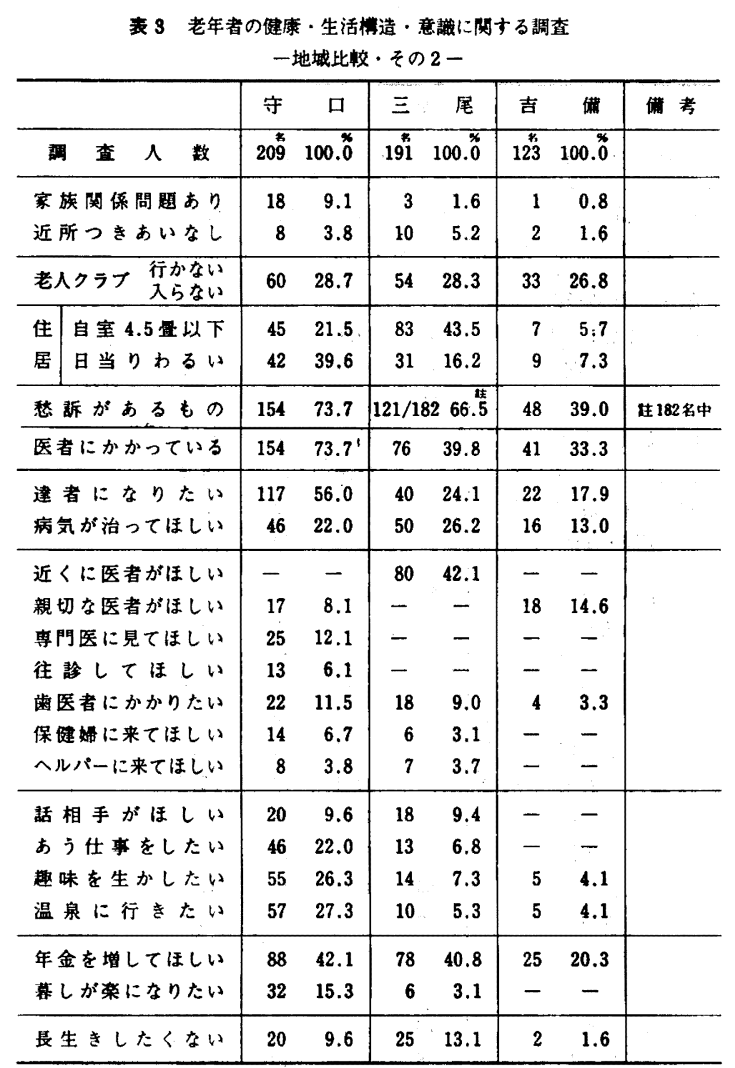

主食は, 吉備では91\%が米飯のみにたいし，守口と三 尾では米飯とパンの併食が半数近くある(朝食).

副食の種類は, 「毎日食べる食品」で, 獣肉よりも魚 を好むようである.とくに，吉備の男，魚 (98\%). 牛 乳は三尾では男女とも $40 \%$ 台, 守口, 男も牛乳が $36 \%$, 吉備は少ない. 卵は守口, 三尾, 男女とも30～40\%台, 吉備はやや少ない，守口の女の60\%は牛乳を稀にしか摄 らない，三尾では，「カナダ帚り」の風習が残っている ようである.

\section{6. 住まいと入浴}

老人が「いつる居る部屋」の大きさは 4 畳半以下が, 吉備では $6 \%$ に過ぎず，守口 $22 \%$, 三尾は半数に近い (44\%). 守口は借家が多く, 半数が住まいについて要望 を持ち, 庭がほしい, 日当りのよい部屋, 静かな部屋, 1 人部屋を求めている. 劣悪な居住条件は老人の住生活 にしわよせられている. わが国の漁村では一般に零細住 居が多いが，三尾でもみとめられる．しかし日当りはよ い. 吉備では住居条件はもっともめぐまれている.

入浴は, 守口では入浴より遠ざかっている老人があり, 週化 1 回以下 9 名 (4\%), 月に 1 回以下 5 名. 有病老
人，独居老人では，入浴介助をもとめるものがある。

\section{7. 老人の悩みと要望（贵 3 ）}

1) 健康について

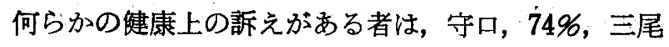
67\%あった. 吉備は39\%である. 愁訴の内容は「健康診 断結果」の項でも述べるが, 心蔵・脈器系の訴えと疼痛 をもつ関節痛, 神経痛などの訴之が比較的多い.

いずれの地区でも，健康は老人の最大の関心である. 守口の老人は, 半数以上が「達者になりたい」, 24\%は 「病気が治ってほしい」という.三尾では「病気が治っ てほしい」26\%。「「達者になりたい」22\%ある. 吉備で む, 前 2 者よりあやや低率であるが;「達者になりたい」 18\%，「病気が治ってほしい」13\%あり，老人の健康人 の願望は強い。

\section{2) 医療事情について}

受診状況：「医者にかかっている」は，守口では74\% にたいして, 三尾では40\%，吉備39\%であり，かなりの 差がある.

医療に対する要求 : 老人の健康状態と意識, 地域の医 療事情によって異なるが, 三尾では $42 \%$ 「近くに医師 がほしい」といい，まず無医状態の打開を求めている. 守口では, 医療機関が多く, 老人の受診率は高いが,「医 療の内容」についてはかならずしも満足していない。

「専門医にかかりたい」12\%，「親切な医師がほしい」 $8 \%$, 「往診をしてほしい」 $6 \%$,「健康診断をしてほ しい」13\%，「相談にのってくれる医者がほしい」7\% という.また「歯医者にかかりたい」12\%，「マッサー ジをしてほしい」14\%,「保健婦の家庭訪問をしてほし い」5\%：「温泉に行きたい」が27\%もあり，都市老人の レクリエーションにたいする要求むつよいといえよう. 吉備では地域内に医療機関があるが，「親切な医師がほ しい」15\%ある.

\section{3) くらしについて}

65才以上の老人の $90 \%$ は何らかの年金をうけており， 年金にたいする期待が大きく，守口，三尾の老人は $40 \%$ が「年金増額」を求めている. 吉備では増額を求める者 は20\%である. 家族同居のために老人の生計負担感覚が 薄いためであろう. 守口では「暮しが楽になりたい」15 \%あり, 都市老人の生活難感覚を示唆している. また 22 \%が「あう仕事」を求めており, 他の 2 地区に比べて有 意に高率である. 前述のごとく, 守口の老人, とくに男 は「働き」に類する暮しが少なく，無聊をかこつだけで なく, 生活難感覚もあり, 何か「する仕事」を求める傾 向が強いようである.

\section{4) 人間関係について}


「家族とうまくいかない」老人が，守口では $9 \%$ あ り，三尾，吉備町とは有意の差をみとめ（危険率 $1 \%$ 以 下)，都市老人の「家族との赫外」を示している.

また独居老人が多い守口及び三尾では「話相手がほし い」老人が10\%ある, 吉備の老人にはその種の訴えがな く、「家族とのつながり」を示唆している.

\section{5) 畏生きについて}

「長寿」は誰しも願うところであるが，現実に老人の 「長生き」にたいする意識は, その主体的条件と客観的 条件が絡みあい，さまざまである，「長生きしたくない」 老人は，守口では 10\%。 三尾では13\%あり，吉備では 「長生きしたくない」は2\%にすぎない.「長生きした くない」老人は, 高令, 独居, 病気, 家族関係がよくな いものなど, 問題を抱えている.

老人対策の重点目標は, これらの老人の「生きる望み」 をうしなわせるものをつきとめ，それを打開することで あるう。

\section{II. 守口市と和歌山畺三尾地区における老年者健康部}

\section{断結果の比較と老人保健医療対策（表 4)}

両地域における老人の健康診断の結果を比較する.

\section{1. 自觉症状}

65才以上の老人を健康診断した結果, 自覚症状を有す る者は, 守口では96\%, 三尾では83.7\%，ともにすこぶ る高率である. 守口市の老人は, 種々の自覚症状を重複 して訴充, 1 人当り 4.1 件の病訴がある. 三尾では 1 人当 り平均 1.65 件である.

訴えの種類 : 守口では筋・関節・骨格系の訴えが最も

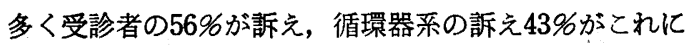
つづく，呼吸器系の訴え $32 \%$ ，見えにくい21\%などが多 い訴えである.

三尾でも，筋・関節・骨格系の訴えがもっとも多く 35 $\%$, ついで脳・中枢神経の訴え $30 \%$, 呼吸器系の訴え 22 $\%$, 心臓循環器系の訴え $17 \%$ がつうく, 一般に各種の訴 えともに守口よりは低率である。

\section{2 , 有所見者}

健康診断による有所見者率は，守口96.6\%, 三尾98.8 \%ともにほとんど全員に何らかの異常所見をみとめた， また合併症を有するすのが多い，三尾の老人は，1 人当 り平均 1.7 件の異常所見を認め, 守口はさらに重複し, 1 人当り 2.6 件の疾病または異常所見を有する.

\section{異常所見の種類}

守口, 三尾ともに, 循環器系の異常所見または疾患の 有所見率が60\%台であり，もっとも高率である，心電図 異常所見 : 守口 $47 \%$, 三尾 $51 \%$, 高血圧症 : 守口 $42 \%$,
表 4 老人健康診断結果

一地域比較一

\begin{tabular}{|c|c|c|c|c|c|}
\hline & 守 & 口 & $\equiv$ & 尾 & 備 \\
\hline 対 傮 者 数 & 175 & $100.0^{7}$ & 86 & 100.0 & \\
\hline 病 哌 あ & 168 & 96.0 & 72 & 83.7 & \\
\hline 病訴者 1 人当り訴元数 & & $.3 \pi$ & & $0 \pi$ & \\
\hline 脳 - 中枢神経系の訴え & 111 & 63.4 & 26 & 30.2 & \\
\hline 感党器系：見えにくい & 51 & 29.1 & 12 & 14.0 & \\
\hline 閭えにくい & 36 & 20.6 & 15 & 17.4 & \\
\hline 心朠・眽管系の訴え & 75 & 42.9 & 15 & 17.4 & \\
\hline 呼吸器系の訴え & 56 & 32.0 & 19 & 22.0 & \\
\hline 消化器系の 訴之 & 78 & 44.6 & 11 & 9.3 & \\
\hline 泌尿器系の訴え & 31 & 17.7 & 2 & 2.3 & \\
\hline 筋・㒺節・骨格系の新え & 98 & 56.0 & 30 & 34.9 & \\
\hline $\begin{array}{c}\text { 有 所 見 者 数 } \\
\text { 有所見者 } 1 \text { 人当り異常所見数 }\end{array}$ & 169 & $\begin{array}{r}96.6 \\
.7\end{array}$ & 85 & $\begin{array}{c}98.8 \\
8 \%\end{array}$ & \\
\hline 楉 & 10 & 5.7 & $(5)$ & $(5.9)$ & （）康结管性者 \\
\hline 惯 血症 & 11 & 6.3 & 9 & 10.5 & \\
\hline 精 神 機 能 低下 & 16 & 9.1 & 4 & 4.7 & \\
\hline 感党器 - 神経系疾甞 & 72 & 41.1 & 23 & 26.7 & \\
\hline 循 㻓器系疾恕 & 100 & 66.6 & 57 & 66.3 & \\
\hline 高 血 圧 症 & 73 & 41.7 & 36 & 41.9 & \\
\hline 心電図異常おり & 83 & 47.4 & 44 & 51.2 & \\
\hline 心筋硬 塞 & 3 & 1.7 & 7 & 8.1 & \\
\hline $\mathrm{S} T \cdot \mathrm{T}$ 異常 & 31 & 17.7 & 26 & 30.6 & \\
\hline 不整 脈 & 8 & 4.6 & 6 & 7.0 & \\
\hline 心 肥 犬 & 18 & 10.3 & 6 & 7.0 & \\
\hline . 左房肥大 & 6 & 3.4 & 10 & 11.2 & \\
\hline 呼 吸器系疾急 & 30 & 17.1 & 3 & 3.5 & \\
\hline 消 化 器系疾 虫 & 11 & 6.3 & 3 & 3.5 & \\
\hline 泌尿 器系疾忽 & 39 & 22.3 & 4 & 4.7 & \\
\hline 皮痁疾甞 & 6 & 3.4 & 2 & 2.3 & \\
\hline 筋·阅節 ·冎格系疾患 & 59 & 33.7 & 21 & 24.4 & \\
\hline
\end{tabular}

三尾42\%である. 次いで腰痛症 : 守口 $20 \%$, 三尾 $15 \%$, 神経痛: 守口 $14 \%$, 三尾14\%, 難聴: 守口15\%, 三尾14 \%などであり，これらの有病率は両者で近似する，但 し, 守口の老人は気管支炎, 夜間頻尿, 白内障が三尾の 老人よりる有意に高率である. 他方，三尾の老人は心筋 硬塞と全血比重低值者が守口の老人よりる有意に高率で ある (ともに $5 \%$ 以下の危険 率). 血液臨床化学検査結 果は両者に有意差をみとめない。

さて, 守口の老人では呼吸器疾患有病率が三尾の老人 よりむ高いことについては, 守口市は大気污染公害病指 定地域であり，実際に受診者のなかに公害病認定をうけ ているものがある.これにたいして三尾地区は気候温暖 な沿海地域であることが関係しよう. 三尾の老人は心筋 硬塞が守口の老人よりも有意に高率であることは，80才 以上の高令者が多いことが関係しよう. (80才以上は80才 未満に比べ, 心筋硬塞が有意に高率である, 危険率1.5\%) 


\section{3. 有所見者の受彰状況（表 5 ）}

調査当時，「医師にかかっている者」は守口81.7\%， 三尾44.7\%であり，顕著な差がある．また健康彰断の結 果, 要治療または医師による指導を要すると判定したも ので「医師にみてもらっている」ものは守ロ90\%にたい して, 三尾では $53 \%$ ，すなわち要医療者の半数近くは医 師にかかっていなかった。これらの有所見者の多くは愁 訴をもっていることを考えると，三尾の老人には「がま ん型」が多いように見うける.これには当地が無医状況 であることが影響していると考えてよかろう. 三尾地区 における無医状況の解消は緊急な課題である.

表 5 健康診断判定区分と受診状態

\begin{tabular}{|c|c|c|c|c|c|}
\hline & & 守 & 口 & & 尾 \\
\hline \multicolumn{2}{|c|}{ 受 診 者 数 } & 175 & 100.0 & 86 & $100 \%$ \\
\hline \multirow{3}{*}{$\begin{array}{l}\text { 判 } \\
\text { 定 } \\
\text { 区 } \\
\text { 分 }\end{array}$} & 要治療 & 114 & 65.1 & 54 & 62.8 \\
\hline & 要指 導 & 31 & 17.7 & 22 & 25.6 \\
\hline & 要注意 & 23 & 13.1 & 9 & 10.5 \\
\hline \multicolumn{2}{|c|}{ 要治療·要指導者 } & 145 & $100 . \%$ & $\begin{array}{l}y_{1} \\
76\end{array}$ & $100 . \%$ \\
\hline \multicolumn{2}{|c|}{ うち受診している } & 130 & 89.7 & 41 & 53.9 \\
\hline
\end{tabular}

老化に伴い身体能力低下と疾病り患の可能性が強まる のは必然である. 老年者の大部分は何らかの異常所見か 疾病を認める.「老人医療」に関して必要なことは,「受 診抑制」ではなく．各地の老人が要求するように「医療 内容」の改善である. さらに大切なことは, 老人保健対 策のあり方である. 有病者にたいする治療はもちろん， 継続的な健康状態の観察と療養指導が必要，不可欠であ る. 病者あるいは心身機能低下者に対する在宅看護, 介 助に加えて，老人の日常において保健に関する相談と援 助をおこなう健康管理医の活動と保健婦・看護婦の協同 作業による「老人健康管理」のとりくみが，老人保健対 策のかなめとなるだろう.

\section{III.「長寿村」について}

三尾地区が「長寿村」とよばれている点について，調 查の結果，老令人口の割合が異常に大きいことが明らか となった，また同地区出身者が青壮年期にカナダなどに 渡航・移住し，老後・帰郷する風習があり，現住老人の 男の半ば近くがこれら老後州郷者によって占められてい ることがわかった. 高令の老人が多い点について，老人 死亡調査の結果，高令の老人，とくに老女の死亡率が全 国水準よりも低いことが推定された。但し，これが一時 的現象であるか，継続的事象であるかを，確認する必要
があり，断定をさけたい。

\section{考察}

\section{1 老人医療之健康管理}

1963年, 老人福祉法制定以来, 65才以上の者に対して 市町村長による健康診査が行われている. 1980年に洼全 国で246万 3 千人が受診し，要療養者は46.5\%であった。 老人の健康状態に関する調査報告によると，老人の $70 \%$ は何らかの病訴をもっいる1といい，また老人の愁訴率 は40\%であったが, 健康診断により有病者78\%が診断さ れた2) という.J. Meyer は「老年人口の70～85\%は少く とも 1 つあるいはそれ以上の慢性の不調 (disorder)をも っている12)という：著者は都市と漁村における老人の 健康診断の結果, 受診者の $80 \%$ 以上が何らかの愁訴をる っており，また909前後に何らかの異常所見をみとめ, 要治療者 60 数\%, 要指導者 $20 \%$ 前後と判定した。

老化 Aging にともない，身体的・精神的機能の低下， 身体不調あるいは何らかの病身になることは避け難い。 老人の不健康は多くは非可逆的であり，完全な健康回復 は必ずしも期待できない，老人には若年者と同様な「絶 対的健康」は望みえないが，いわゆる「一病息災」で， たとえ不調や異常所見があっても，悪化することなく， 日常生活を営みうるならば，これが「老人の健康」とい ってよかろう．著者は本調査の知見にもとずき，老人医 療は「治療」の枠内にとどまらず，日常における継続的 な健康観察と生活援助あるいは指導が必要であり，「健 康管理」を基調とするものでなければならないと考え る. 大和田も「健康とは相対的概念であるから, 老人に ついての健康を若壮者と同様の意義でとらまえる必要は ない」13）という．奈倉は老人の健康状態と医療状況を追 跡調査した結果，「老人の医療は，致命的な医療を必要 とする場合を除いては, 疾病の治療よりも管理が必要で あり, 疾病および病的老化によって起る生活能力の低下 を防止したり改善したりするリハビリテーションや心身 の保全をはかる看護が中心となる管㻔的医療が主体でな ければならない」14)と述べている. 著者の調査において 老人は「医療に対する要望」として「健康相談」と「保 健婦の訪問活動」を望えでいる点に注目したい。

老人にたいしては，有病者にたいする治療のみなら ず, 継続的な健康状態の観察と療養指導が必要である. すなわち，地域における老人保健対策は，治療と在宅看 護, 介助に加えて日常生活における保健指導・援助を稼 こなう「老人健康管理」のとりくみでなければなるまい.

\section{2. 在宅看讙と介助について}

病む老人には勿論，行動不自由な高令者にたいする在 
宅看護と介助の必要性について.多くの報告がある15一 21).著者は 3 地域における老人調查と,別稿「寝たきり老 人・独居老人の訪問調查」において，老人にたいする在宅 看護と介助が不十分な事実を認めた，病老人にたいする 看護と介助はほとんど家族によっておこなわれている が，家族のなかにはその負担に耐えかねているるのがあ る, 独居老人の場合, 週 $2 \sim 3$ 回, ヘルパーの訪問をう けるむのがあるが，短時間であり，日常生活の介助まで 行き届かないものが多い：往診も十分でない，もとも と，老人にたいする医療は，医師の診療だけでは不十分 である. 主治医と連係を持ちつつ, 看護婦とールパーが 老人の生活の場における日常的な Care が必要不可欠で あ万う．老人が「往診」ととむに「保健婦活動」を求め ている点に注目したい。

実際に, 地域病院が退院した老人，とくに脳卒中患者 に対して訪問看護を行って22) いる事例, 地区医師会と 自治体，保健所が協力して，齐たきり老人を調査し，主 治医と, 保健婦, ヘルパーらの協同治療により在宅看護 と介助活動を行っている事例23) 24)などがある. 著者が 調查した和歌山県三尾地区では, 当地在住の保健婦と一 ルパーが老人の在宅看護，保健指導，介助について積極 的な活動を続けており，これが無医状況を補い，老人保 健の成果をあげているように思える.

老人に対する地域看護・介助事業と主治医（家庭医） との連係はイギリス25)26)，スエデン27)などでは完全 に制度化されているが，わが国では未発達であり，この 方面の改善こそが，これからの老人対策における課題で あろう。

\section{3. 循環器疾患について}

健康診断の結果, 守口, 三尾, 両地区ともに循環器系 の異常所見率が高く60\%台であった. 受診老人の半数に

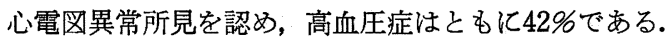

$\mathrm{ST}$ TたはTの異常は守口20\%，三尾30\%であり，三尾 ではやや高率である. 三尾の場合, 高令者ほど, S T たはTの異常が高率であることを認めた。つゔいて心肥 大, 不整脈, 脚プロック, 徐脈索認めた。 心筋硬塞所見 は三尾 $8 \%$ (高令者に高率), 守口 $2 \%$ ある.

小沢によると，「心電図所見も加令にともなって異常 の頻度を増すが，とくにS Tの低下滈令となるほど高 率となる.90才代では健常者でも約 4 割は虚血性 S T 低下が認められる。しかもこれは，収縮期血圧のレベル に極めてよい相関を示している……洞房結節の細胞も 老人では減少し，線維性組織により置換えされる．これ は老年者の伝導障害や不整脈の基礎病变となるわけであ $3^{28)} 」$
杉浦によると刺戟伝導障害で「加令と相関あるのは, 1 度房室ブロック，脚ブロック心軸偏位，期外収緶，心 房細動, 洞徐脈である. 老年者の刺戟伝導障害の相対頻 度は洞徐脈，洞ブロック，洞停止をあわせると $15.1 \%$ 亿 なる29)」という.

守口, 三尾両地区ともに，男は女よりも脚ブロック， 不整脈が高率である．S T 異常のうち，最も多いのはV 5^6 S T低下であり，守口では $V_{5 \sim 6} S T$ 低下は女が男よ りも高率（有意）であるが，三尾では有意差をみとめな い.

高血圧症の有病率は守口と三尾ともに $42 \%$ ありり, 全 国並みと見てよい，高血圧症者の心電目所見は，非高血 圧症者に比べて，心肥大の頻度が大きい，また守口での 所見では，心電図異常所見を有する者は異常所見を有し ない者に比べて中性脂助高值者が有意に高率であった。 三尾では有意差をみとめない。

三尾地区において，1973年以降 5 年間の老人死亡の死 因別構成比は，全国統計に比べて，脳血管疾患死亡が少 ないが，有意ではない。

老人保健対策の焦点は，頻度が大きく，主要死因とな る循環器疾患の対策である. 高血圧症, 脳卒中, 心疾患 とくに虚血性心疾患の予防，早期診断，早期治療亚びに 継続的観察と健康管理によって, これらの老年者に好発 する病の予防あるいは悪化防止に成果をあげている事例 が報告されている（長野県八千穂村，大阪府八尾市，秋 田県井川町など 30) 31)，脳卒中一高血圧症対策が 多い が，今後，心疾患死亡の増加が見込をれ，脳血管疾患の みならず，虚血性心疾患はじめ心疾患の予防と健康管理 が主要な老人保健対策の課題となろう32).

\section{4. 老人の世帯構成と生活構造}

老人のくらしはその世帯構成，すなわち家族同居，老 夫婦，独居により相違がある. 農村では老人のほとえど は家族同居であり，都市では核家族化がすすみ，老夫婦 之独居老人の割合が大きくなる，漁村では独居老人がと くに多い.

老人の日常の生活構造は都市と農村によりいちぢるし いちがいがある，農村では，男女とも田畑の仕事，家業 家事など，毎日，仕事があり，老人も有力な労働力であ る.なかには「仕事がきつい」と訴えるものがある．他 方, 都市では，停年退職後，「働きごと」がなく，半ば は「勝手なこと」で時間をつぶし，女も家事以外に「す ること」がなく，無聊をかこつ傾向がある．都市老人は 「働きごとをしたい」「社会奉仕をしたい」「趣味を生 かしたい」「旅行・温泉」などのレクリエーションにた いする期待む大きい，老令化社会にむけて，老人の「生 
きがい」は主体性をもって社会の一員として「生きる」 ことである. 保護. 介助にとどまらず，老人の「社会参 加33)」の場が地域社会において用意されることである j.

現代都市における「住生活」の困窮は老人にしわよせ られていることが，この調查で明らかにされた，老人住 宅対策はいちぢるしく立ち遅れているが，今後の重大な

\section{全編のまとめ}

高令化社会にむけて老人問題は益々重要性を增してい るが, 近年, 老人医療問題が重点課題となっている.

「健康とは身体的, 精神的並びに社会的に完全に良好な 状態である」(WHO憲章) ということは，とくに老年者 にとって重要な意義をむつ，著者は，長年の地域巡回診 療活動を通して, 老人の生活と意識の特殊性を考虑に入 れた老年者保健医療対策が必要であると考光，そのあり 方を究明することを目標とした調査研究を都市, 農村, 漁村の三地域においておこなった。従来，かかる見地か らの調査研究はほとえどなく,わが国における老人保健 の実際に役立つことを期待している.

調査研究怡大阪府守口市(都市), 和歌山県美浜町三尾 (漁村), 和歌山県有田郡吉備町(農村) において, 1978 年 4 月以降1980年 3 月の間に実施した。調査対象者, 65 才以上の老人は全て任意抽出により選んだ, フンゲート 調査は守口 209 名, 三尾191名, 吉備123名, 健康診断は 守口 105名, 三尾83名である. 各地域における調査結果 及びそれらの比較検討を 4 編にわけて報告した. その内 容をとりまとめて要約する.

\section{I. 人口調查・死亡調査}

1 老年人口の割合：3地区の65才以上人口の総人口 に対する割合は, 守口が最も少なく $6.9 \%$, 三尾では最 も大きく24.9\%, 特に75才以上の高令者の割合が大き く, 人口ピラミットは特異である. 吉備は $18.5 \%$, 中間 に位置する. 三尾の住民は青壮年期にカナダ方面に出稼 ぎ移住し（主に漁業），老後，帰郷する風習がある，調 査の結果, 男の老人の $40 \%$, 女の $30 \%$ が老後帰拫者によ って占められ，老年人口の比重を増大していることが明 らかとなった。

2 三尾における死亡調查！「長寿村」と称される人 口構成と関連して, 死亡について調査をした結果, 高令 者, 特に女の死亡数は. 全国值より標準化した期待値よ り少ないことを認めた．死因については老衰と心臓疾患
課題である.

老人にとって「食生活」はかけがえのない“楽しみ” でもある. しかし独居老人の食生活は「提取熱量が低く 栄養のバランスがとれていない34)」. 老人の食生活への 対応は, 生計, 行動能力, 食習慣, 㖺好, 咀嚼力等, 個 人差が大きく,きめの細かい配虑が必要である.「老人 給食サービス」は重要な老人対策であろう。

による死亡数が死亡期待数より大きく（危険率 $1 \%$ 以 下), 高令の老人が特に多いことと符号する.

\section{II. アンケート調查}

\section{1 配偶関係と世帯類型}

各地区共, 男の70〜80\%が有配偶であるに対して, 女 の有配偶がは $30 \%$ 前後である.

家族同居, 吉備では $95 \%$, 他は半ば前後, 三尾では 1 人暮しが多く23\%，殆えど女である。「独居老人問題」 汇「女性問題」である.

2 日常生活構造: 男の場合, 地域差があり, 吉備で は，大部分が田畑等の「働きでと」，守口では「働きご と」が少なく，過半は「勝手な事」，三尾では「働きご と」と「勝手な事」が相半ばする，女の場合，いずれる 「家庭のこと」が過半を占め, 残りは, 三尾, 吉備「働 きごと」，守口は「勝手な事をする」，老人にも「働き」 の比重が「生きがい」につながり，守口の老人（都市老 人）は「する仕事」を求め, 無聊をかこつ傾向がある.

3 日常生活能力: 高令者が多く独居老人が多い三尾 では要介助が多い(14\%)。吉備がこれに次ぎ，守口は 少なく，全国大都市なみ.

4 食生活 : 吉備はほとんど米食, 三尾と守ロはパン と併食, 「毎日食べる」副食物は野菜のほが, 吉備の 男は魚 (98\%), 三尾は男女共牛乳 (40\%), 守口の男, 牛乳 (36\%), 守口の女吽乳を好まない (60\%). 海草 はいずれも「ときどき」が多い，三尾では一部にカナダ 帰りの風習あり。一般に独居老人の食生活は単純であ り，栄養上問題がある.

5 住まいと入浴：住まいの条件は老人の生活に如実 に響いている. 4.5畳以下の狭い居室が三尾は半ば近く， 守口は22\%, 吉備は最むゆとりがある. 守口では日当り が悪い，庭がほしいなどの苦情が多い．また入浴に困っ ている老人がかなりある.

\section{6 悩みと望み}


1）健康意識と受診状況：いずれの地域でも，老人の 最大の関心事は健康である. しかし受診事情は異なる。 守口では受診率 $74 \%$ に対して, 三尾は $40 \%$ ，吉備は $33 \%$ で，かなり低い。

2) 医療に対する要求 : 三尾で注半数近くが「近くに 医者がほしい」, 守口では受診率は高いが，「専門医」， 「親切な医者」「健康診断」「往診」等の要求がある。

3 ）くらしについて : 守口と三尾の半ば近くが年金増 額をのぞみ，また守口の老人は「あう仕事」をもとめて いる.

4) 人間関係 : 守口の老人は吉備, 三尾の老人よりも 「家族とうまく行かない」者が多い（とくに女の高令 者, 独居老人）「話し相手」をもとめるものが，守口と 三尾ではやや多く，「家族同居」が多い吉備ではほとん どない.

5）長生きについて：長寿は誰しも望むことである が，実際には老人の主体的条件と客観的条件がかわって いる.「長生きしたくない」老人は三尾が最も多く，守 口はこれにつぎ, 吉備は少い.「長生きしたくない」老 人は高令, 病気あり, 家族内に問題あるなどがかわって いる.

\section{III. 守口市と三尾地区における健康診断結果}

\section{1. 自覚症状}

何らかの自覚症状を有する者が守口 $96 \%$ ，三尾 $84 \% ，$ あり. 1 人当り自覚症状数は守口 4.1 , 三尾1.7であり, 守口の老人が各種の訴えを重複して訴えている.

\section{2. 有所見者}

何らかの異常所見を有する者の率は, 守口は $97 \%$, 三尾は84\%であり，ともに高い.

異常所見の種類：両者はかなりよく近似する点が注目 される.

まず循環器系の異常所見の発見率が最も高く,ともに $60 \%$, 心電図異常所見：ともに50\%前後, 高血圧：とも 飞42\%, 腰痛 : 守口 $20 \%$, 三尾15\%, 神経痛 : ともに14 \%，難聴14\%～15\%であり，いずれる類似する．ただし 守口の老人は気管枝炎, 夜間頻尿, 白内障が三尾の老人 よりる有意に高率であり，三尾の老人は全血比重低值者 と, 心電四所見・心筋硬塞の発見率が守口よりも有意に 高い（危険率 $5 \%$ 以下).

守口は三尾に比べて呼吸器疾患の有病率が高いととに は, 大気污染公害病指定地域であるに対して, 三尾は温 暖な海岸であることを考慮に入れてよかろう. 三尾の老 人の心筋硬塞が守口の老人よりも高いのは高令者が多い ことが関係している（80才以上が80才未満に比べて有意
に高率である，危険率 $1 \%$ 以下).

血液瀶床化学検查成績は両地域の間に著差を認めな い.

守口の所見で, 高血圧症は心電図異常, とくに心肥大 が有意に高率である. 三尾の前職漁師の老人は高血圧症 が有意に低率である。但し海外渡航移住歴の有無によっ て高血圧及びECG異常の有所見率に差をみとめない.

概していえば，両地域の老人の有病者率には大きな差 はないが, 合併症は守口の老人が多い。

\section{3. 有所見者の受診状況}

要治療又は要指導と判定したものの健康診断の当時の 受診率は, 守口 $90 \%$ に対して三尾は $54 \%$ であり, 顕著な 差がある.これには三尾が無医地区であることがひびい ていよう. 三尾の老人も守口の老人におとらず愁訴率が 高いことを考えると，「がまえ型」が多いと判断される.

\section{むすび}

一老人保健医療対策の方向づけのために一 大阪府守口市 (都市), 和歌山県美浜町三尾（漁村）およ び和歌山県吉備町（農村）に括いて，老人の健康と生活 構造，並びに意識について調査した結果を報告した。そ れらの知見から, 現代の老人保健医療対策において参考 にされてよいと考光る諸点を摘記すると，

1.「長寿村」と称せられる三尾地区では，青壮年期 海外出稼ぎと老後帰郷による老年者人口割合の增大を認 めた. あわせて高令者，特に老女の死亡率が全国水淮よ り低い傾向をみとめた。

2. 守口, 三尾における老人健康診断の結果，ともに ほとんど全員が何らかの異常所見を有し，要治療者63〜 $65 \%$, 要指導者 $20 \%$ 前後, 要注意者 $10 \%$ 台である.

3. 異常所見の種類は, 両地区の老人に類似点が多 い. 特に心蔵脈管系疾患の発見率 $60 \%$ 台で最も高く, 老 人保健対策の重点目標となろう. 腰痛, 神経痛, 難聴な どが続く。

4. 要治療および要指導者の健診当時の受診率は守口 の90\%に対して，三尾では54\%であり，無医地区である ととが関係しょう，但し守口の老人は愁訴が多く，尃門 医受診, 往診, 健康診断などを求めている. 三尾の老人 には「がまえ型」が多いようである。

5. 独居老人はほとんどが老女である，家族同居は守 口 (都市) と三尾 (漁村) は50\%前後, 吉備 (農村) 95 \%である.

6. 要介助老人は守口 $5 \%$, 三尾 $13 \%$, 吉備 $11 \%$ で, 高令老年人口の割合と平行する.

7. 守口(都市)の老人は「働きごと」が少なく, 無聊 
をかこっている傾向がある. 吉備(農村)の老人は「働き ごと」が多く, 三尾 (漁村) の老人は前 2 者の中間であ る.

8.「長生きしたくない」老人が守口と三尾で10\%台 であり，病気，高令，家族関係に問題があるなどの老人 に多い.

9. 老人の「生きがい」には, 健康, 人間関係, 年金, 生活時間の充実などがかかわっている. その対策には地 域特性を配虑し，老人のくらしと意識を重視する必要が ある.

10. 老人保健対策については, 老化任伴う必然として 「絶対的健康」は必ずしも望み難く, 日常生活化支障を 来さない健康の保持と病勢進行防止を図る「健康管理」 が重要である.「治療」一辺倒でなく, 継続的な健康観 察・相談・指導と在宅看護・介助を総合した, 健康管理 医，保健婦，看護婦，一ルパーなどの協同作業が要望さ れる. 農漁村では無医状況の解消と, 保健婦, 地域看護 婦の活動が特に求められる.

本研究は, 老人の健康と生活構造, 並びに意識に関す る実態と地域特性を明らかにするとともに，老人保健医 療対策のあり方走唆し得たものと考光る.

擱筆するに当り, 本研究について終始御指導を賜わ り，本稿の御校閲を戴いた東田敏夫教授に対して厚く お礼を申しあげます．本研究報告にあたり御指導，御 校閲を戴いた原一郎教授並に塩田登志也教授に対して 深く謝意を表します. 本研究に当り始終御指導, 御協 力を戴いた関西医大公衆衛生学講座橋本美知子講師並 びに高坂祐夫，上田照子諸氏に対して厚くお礼を申し 上げますままた心電図診断など，御指導を戴いた関西 医大内科第 2 講座篠田裕司先生汇謝意を表しをす。

なお本研究に協力された守口市役所関係各位並に和 歌山県美浜町役場関係各位に対しお礼を申し上げま す.

\section{参考文献}

1）西尾雅七：環境と老年者の医療，日本老年医学 誌, 1, Suppl. 97, 1964.

2）大和田国夫：都市老人の保健対策，公衆衛生，32， 341 347, 1968.

3）長谷川恒雄 : 老人医療と技術集積, 日本医師会雑 誌, 82, 91〜97, 1979

4）曾田長宗, 三浦文夫編 : 老人白書, 198年版 碩 文社, 1980 .

5）䉀野脩一; 高令化社会と老人問題, 老人の健康問 題, 118 123, 1978.

6）早瀬正二 : 老年病対策と社会復帰, 日本医学総会 誌, 1374 1388, 1975.

7）小町喜男 : 脳卒中予防を目的とした疫学と地域の 医療, 第 6 回大阪公衆衛生集談会, $1 \sim 31,1980$.

8) WHO : Old age-a problem, for society a whole, WHO Chronicle, 1974, 28, 487〜 494, 邦訳, 公衆 衛生情報, 1975，11.

9）安倍弘毅: 長寿率の研究から, 日本公衆衛生誌, 6, 583 586, 1969.

10）水盘治夫：人口の老化 (aging) と出生率, 死亡率 低下との関係, 63〜70, 1956.

11）横山マキ子：我が国における職業人の労働余命と 平均余命に関する研究, 関西医大誌, 12, 60 66, 1970.

12) J.S. Meyer etal : Diagnosis and management of Stroke and ATls 2 3 Addisorn welsley Pbl. Co. 1981.

13）大和田国夫 : 老年期における健康の概念とその評 価，日本老年医学雑誌，16，122～18，1979.

14）西尾雅七編：老人問題の今後，111～125, ミネル バ書房, 京都, 1976.

15）奈倉道隆 : 病院医療と在宅医療, 高令化社会と老 人問題, $139 \sim 143$, 有斐閣, 1978.

16）前田信雄：病弱老人のディ・ケア，公衆衛生， 42, 586 591, 1978.

17）吉田秀夫他編：老人福祉と老人医療 法律文化 社, 1981 .

18）角田 豊他編：高令化社会と社会保障 法律文 化社, 1980 .

19）賀集竹子：老人の看護, 高令化社会と老人問題, 155 161, 有斐閣, 1978.

20）大国美智子：老年層における医療機関の選択傾 向，(第 1 報）日本公衛誌，24，497～506，1977. 
21）大国美智子：老年層における医療機関の選択傾 向, 日本公衛誌, 25, $7 \sim 14,1978$.

22）青木震雄：老人医療とデイ・ケア，公衆衛生， 42, 564 572, 1978.

23）前田侸雄：病める老人を地域でみる. 垣内出版株 式会社, 1979.

24）推谷沶二 : 東村山市における老人保健福祉活動の 特徴と現状. 公衆衛生, 43, 637 640, 1979. 9.

25) C. F. Brockington, : The Health of the Community, 284 292, J. d, A. Churchill. 1965.

26) A. J. Essex-Cater, : A Synopsis of Public Health and Social Medicine, 386 395, J. Wright \& Sons Ltd, 1960.

27) E. Michanek, : Old age in Sweden, The Swed- isch Institute, 1962.

28）小沢利助：老年者の循環機能. 日本臨床， 39, (3)36〜40, 1981.

29）杉浦昌也：老年者の心刺戟伝動系. 日本臨床，39, (8) $49 \sim 54,1981$.

30）小町男：心疾患・脳血管疾患の最近の疫学的な 動向. 循環科学 1, 818 821, 1981.

31）小町害男：わが国における成人病対策の現況. 内 科, 48, 724 728, 1981. 11,

32）飯田 稔：地域医療としての循環器検診. 管理, 肺と心, $154 \sim 160,1980$.

33）岡村直夫：老人の社会参加. 公衆衛生, 45, 683 $\sim 687,1981$.

34）小野患津子：独居老人の実態. 公衆衛生， 42, 592 596, 1978. 


\title{
（欧 文 抄 録）
}

\section{Studies on the Health, Living Mode and Needs of the Aged}

\author{
Fumiyo Kawabata \\ Department of Public Health, Kansai Medical University, \\ Moriguchi, Osaka, Japan \\ (Supervised by Emeritus Prof. Toshio Higashida and Prof. Ichiro Hara) \\ The Second Department of Internal Medicine, Kansai Medical University, \\ Moriguchi, Osaka, Japan \\ (Supervised by Prof. Toshiya Shiota)
}

The health condition, family structure, daily life and needs of the aged over 65 years old were researched in Moriguch, an urban district in Osaka, Mio, a fishery district in Wakayama and Kibi, a rural district in Wakayama, from April 1978 to March 1980.

1. The result of the research shows that the family structure, daily life and housing condition of the aged have the own characteristics due to the locality.

$95 \%$ of the aged live with their families in the rural district, though half of the aged live in couple or alone in both the urban and fishery districts.

$60-70 \%$ of the female old people are widows and $70-90 \%$ of the aged living alone are female. So "the problem of the aged" might be said to be "the problem of the female".

2. The old people in the urban district have rather more leisure time, smaller sitting rooms and more medical facilities, on the other hand, the old people in the rural districts have rather more agricultural or domestic work, larger sitting rooms and the aged in Mio district have rather more agricultural, fishing or domestic work time, smaller sitting rooms and fewer medical facilities.

3. Mio distrct, which is famous for "the longivity" of its inhabitants, has the larger population of the elder people, nearly half of whom had been abroad, especially to Canada, in their younger age, engaging mainly in the fishery, and returned home in old age.

4. As the result of the health examination of old people, in Moriguchi and Mio districts more than $90 \%$ of the examined have some kinds of health disorders, especially heart and vascural disorders in $60 \%$.

5. Old people need continual health inspection and guidance by family doctors or nurses together with curative service. Home nursing and assistance service in daily life should be provided to the aged sick in bed. 
The comprehensive health service for old people should be provided by family doctors, nurses, public health nurses, helpers and social workers with the encouragement by the public administration, local authorities and volunteer organizations. 